\title{
ANÁLISE DE CRESCIMENTO E PRODUTIVIDADE AGRÍCOLA DE GIRASSOL CONDUZIDO NA SAFRINHA EM CINCO DENSIDADES DE PLANTAS
}

Cristiane de Araujo Monteiro

Engenheiro Agrônomo

Orientador: Prof. Dr. GIL MIGUEL DE SOUSA CÂMARA

Dissertação apresentada à Escola Superior de Agricultura "Luiz de Queiroz", Universidade de São Paulo, para obtenção do título de Mestre em Agronomia, Área de Concentração: Fitotecnia

PIRACICABA

Estado de São Paulo - Brasil

Agosto - 2001 
Dados Internacionais de Catalogação na Publicação (CIP) DIVISÃO DE BIBLIOTECA E DOCUMENTAÇÃO - Campus "Luiz de Queiroz"/USP

Monteiro, Cristiane de Araújo

Análise de crescimento e produtividade agrícola de girassol conduzido na safrinha em cinco densidade de plantas / Cristiane de Araújo Monteiro. - - Piracicaba, 2001.

$94 \mathrm{p}$.

Dissertação (mestrado) - - Escola Superior de Agricultura Luiz de Queiroz, 2001.

Bibliografia.

1. Densidade de planta 2. Época de safrinha 3. Fisiologia vegetal 4. Girassol 5. Produção vegetal 6. Variédade 1. Título

CDD 633.39 


\section{DEDICO A:}

\section{Á MINHA MÄE, ELVINA}

Hoje, apenas quero agradecer pela tua presença em minha vida.

As sementes que colocaste tão cuidadosa dentro do meu coração, cresceram, sobreviveram as secas e grandes tempestades e transformaram-se no amor, na gratidão, na alegria e no amadurecimento que hoje posso oferecer-te. 


\section{AGRADECIMENTOS}

Á DEUS, pai todo poderoso, pelo amor, coragem e presença constante.

Ao Prof. Gil, pela valiosa orientação, grande incentivo e amizade.

Ao Prof. Marcos, pelas contribuições para a realização deste trabalho, e principalmente, amizade.

Á Dra. Regina Ungaro, pela participação na banca examinadora e sugestōes.

Á Escola de Agricultura "Luiz de Queiroz", pela oportunidade de continuar meus estudos.

À FAPESP, pelos recursos concedidos durante o curso de mestrado.

Aos colegas, Axel Garcia y Garcia, Ciro Abbud Righi e Mônica Martins Cagnin, pela amizade, incentivo e colaboração.

Á Clóvis Pereira Peixoto, pela colaboração e grande amizade.

Aos demais colegas da pós-graduação, pela oportunidade de convivio.

Á Helena Pescarim, pela disposição do Laboratórios de Sementes, do Departamento de Produção Vegetal. 
As secretárias do Departamento de Produção Vegetal, Silvia Borghesi e Aparecida Soledade.

Á secretária da Pós-graduação do Curso de Fitotecnia, Ivete Almeida.

Aos funcionários de campo, Celestino Ferreira, Marcelo Batista e Ananias de Souza, pelo companheirismo durante a fase experimental.

As companheiras de república, Ágata Giancoli, Luciana Bianchini e Rosângela Silva, pela grande amizade e convívio.

À Minha Familia, pelo carinho, compreensão e apoio.

E a todos que contribuiram, mesmo que indiretamente, para a realização deste trabalho. 


\section{SUMÁRIO}

LISTA DE FIGURAS …....... ix

LISTA DE TABELAS .................................................................

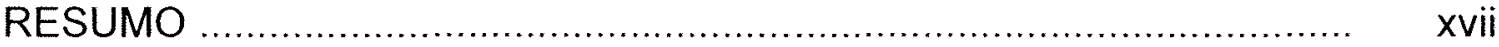

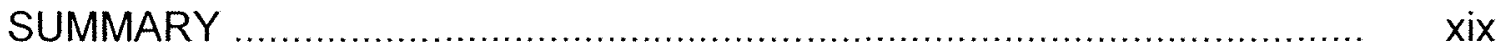

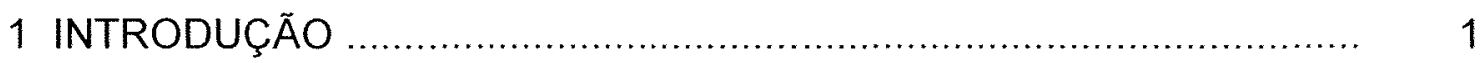

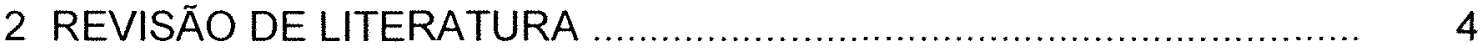

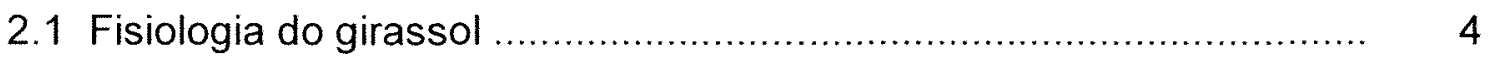

2.2 Época de semeadura .......................................................... 7

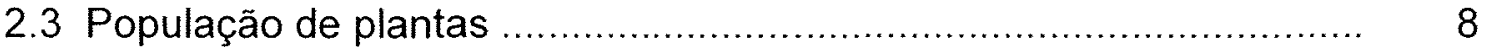

2.4 Análise de crescimento da planta de girassol ............................... 14

3 MATERIAL E MÉTODOS .......................................................... 20

3.1 Local e período de experimentação ............................................ 20

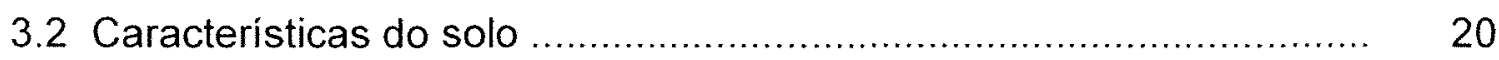

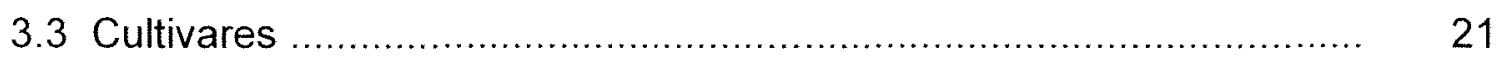

3.4 Densidade de plantas ................................................... 22

3.5 Instalação e Condução do experimento......................................... 23

3.6 Características avaliadas ..................................................... 24

3.6.1 Desenvolvimento fenológico ............................................. 24

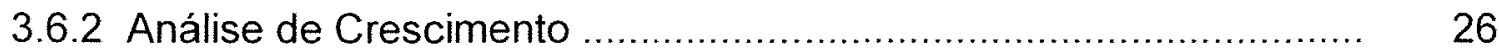

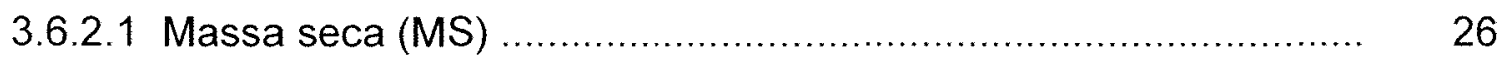

3.6.2.2 Índice de área foliar (IAF) ......................................... 27

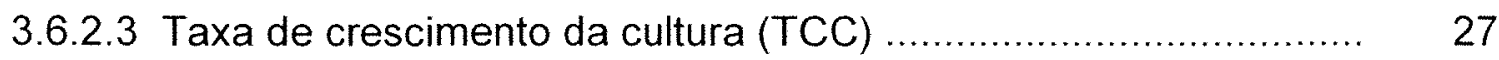


3.6.2.4 Taxa de crescimento relativo (TCR) …................................... 27

3.6.2.5 Taxa de assimilação líquida (TAL) ……................................. 28

3.6.2.6 Razão de área foliar (RAF) .................................................. 28

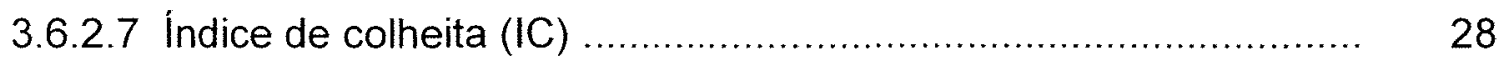

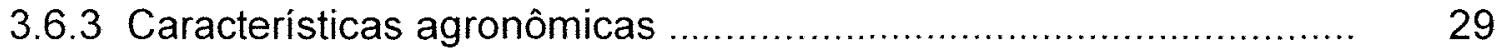

3.6.3.1 Número de Folhas (NF) ..................................................... 29

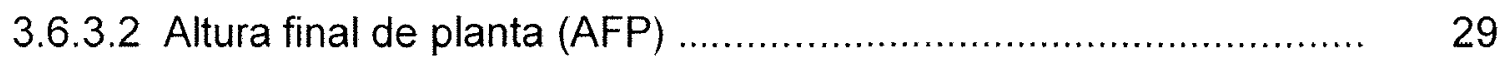

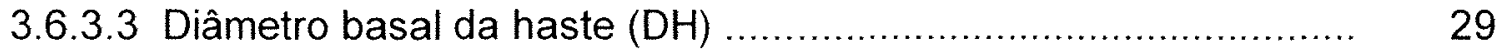

3.6.3.4 Diâmetro de capítulo (DC) .................................................. 29

3.6.3.5 Número de aquênios por capítulo (NA) ..................................... 29

3.6.3.6 Massa de mil aquênios (M1000) …........................................ 30

3.6.3.7 Rendimento de aquênios (REND) ......................................... 30

3.7 Delineamento experimental ....................................................... 30

4 RESULTADOS E DISCUSSÃO …............................................ 32

4.1 Desenvolvimento fenológico e clima ............................................. 32

4.2 Análise de Crescimento .............................................................. 34

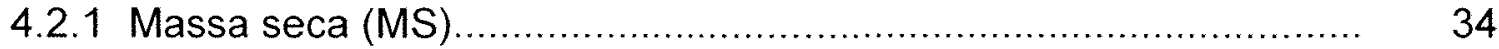

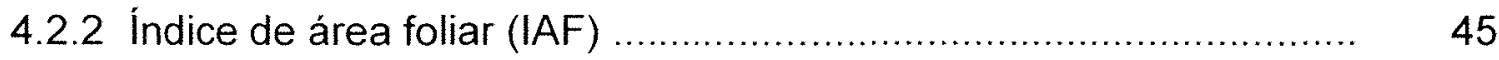

4.2.3 Taxa de crescimento da cultura (TCC) ...................................... 52

4.2.4 Taxa de crescimento relativo (TCR) …..................................... 54

4.2.5 Taxa de assimilação líquida (TAL) …...................................... 57

4.2.6 Razão de área foliar (RAF) ................................................. 59

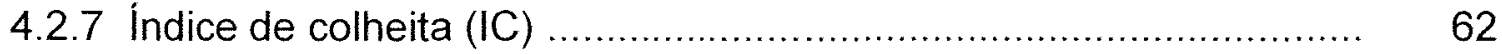

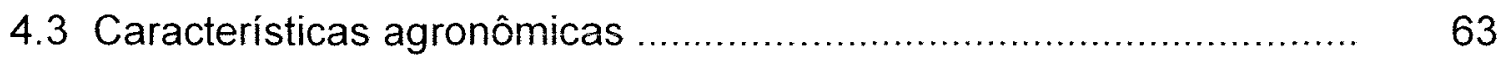

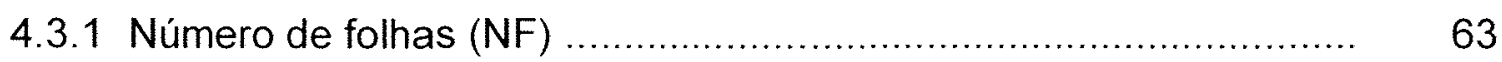

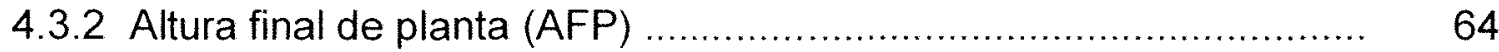

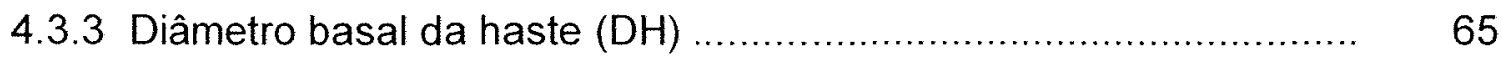

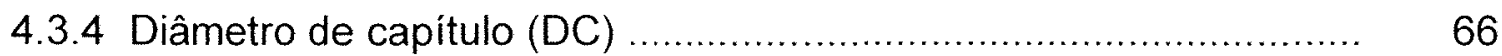

4.3.5 Número de aquênios por capítulo (NA) ..................................... 67

4.3.6 Massa de mil aquênios (M1000) …........................................... 69 
4.3.7 Rendimento de aquênios (REND) 71

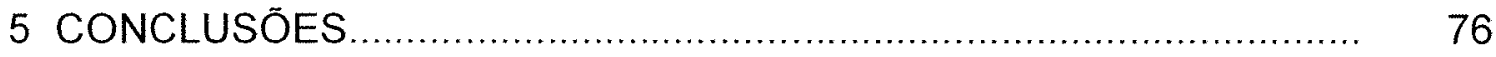

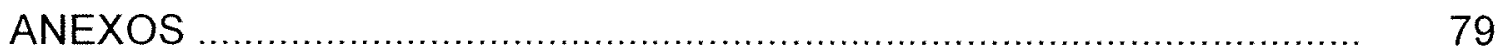
REFERÊNCIAS BIBLIOGRÁFICAS ................................................ 82

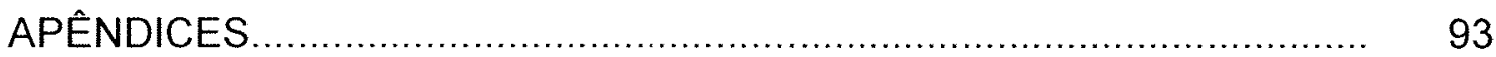




\section{LISTA DE FIGURAS}

Página

1 Massa seca total $\left(\mathrm{g} \mathrm{m}^{-2}\right)$ dos cultivares de girassol C 11 e $\mathrm{M} 734$, no estádio $V_{12}$, em função de densidades de plantas na linha, em época de semeadura safrinha.

2 Massa seca total $\left(\mathrm{g} \mathrm{m}^{-2}\right)$ dos cultivares de girassol C 11 e M 734, no estádio $V_{21}$, em função da densidades de plantas na linha em época de semeadura safrinha.

3 Massa seca total $\left(\mathrm{g} \mathrm{m}^{-2}\right)$ dos cultivares de girassol C 11 e M 734, no estádio $R_{2}$, em função da densidades de plantas na linha em época de semeadura safrinha.

4 Massa seca total $\left(\mathrm{g} \mathrm{m}^{-2}\right)$ dos cultivares de girassol C 11 e M 734, nos estádios $R_{4}$ e $R_{5.1}$ respectivamente, em função da densidades de plantas na linha em época de semeadura safrinha.

5 Massa seca total $\left(\mathrm{g} \mathrm{m}^{-2}\right)$ dos cultivares de girassol C 11 e $M 734$, nos estádios $R_{5.6}$ e $R_{5.8}$ respectivamente, em função da densidades de plantas na linha em época de semeadura safrinha...

6 Massa seca total $\left(\mathrm{g} \mathrm{m}^{-2}\right)$ de girassol para os cultivares $\mathrm{C} 11$ e $\mathrm{M}$ 734 , no estádio $R_{6}$, em função da densidades de plantas na linha em época de semeadura safrinha...................................................

7 Massa seca total $\left(\mathrm{g} \mathrm{m}^{-2}\right)$ dos cultivares de girassol C 11 e $\mathrm{M} 734$, nos estádios $R_{7}$ e $R_{8}$ respectivamente, em função da densidades de plantas na linha em época de semeadura safrinha. 
8 Variação da massa seca total $\left(\mathrm{g} \mathrm{m}^{-2}\right)$ do cultivar de girassol Cargill 11, nas densidades de 2, 3, 4, 5 e 6 plantas por metro, em época de semeadura safrinha.

9 Variação da massa seca total $\left(\mathrm{g} \mathrm{m}^{-2}\right)$ do cultivar de girassol, Morgan 734, nas densidades de 2, 3, 4, 5 e 6 plantas por metro, em época de semeadura safrinha.

10 Índice de área foliar $\left(\mathrm{m}^{2} \mathrm{~m}^{-2}\right)$ dos cultivares de girassol C 11 e $\mathrm{M}$ 734 , no estádio $R_{2}$, em função das densidades de plantas na linha em época de semeadura safrinha.

11 Variação do índice de área foliar $\left(\mathrm{m}^{2} \mathrm{~m}^{-2}\right)$ de girassol, cultivar Cargill 11, nas densidades de 2, 3, 4, 5 e 6 plantas por metro, em época de semeadura safrinha.

12 Variação do índice de área foliar $\left(\mathrm{m}^{2} \mathrm{~m}^{-2}\right)$ de girassol, cultivar Morgan 734, nas densidades de 2, 3, 4, 5 e 6 plantas por metro, em época de semeadura safrinha.

13 Taxa de crescimento da cultura $\left(\mathrm{g} \mathrm{m}^{-2}\right)$ do cultivar de girassol $\mathrm{C} 11$, nas densidades de 2, 3, 4, 5 e 6 plantas por metro de linha, em época de semeadura safrinha.

14 Taxa de crescimento da cultura $\left(\mathrm{g} \mathrm{m}^{-2}\right)$ do cultivar de girassol $\mathrm{M}$ 734, nas densidades de 2, 3, 4, 5 e 6 plantas por metro de linha, em época de semeadura safrinha.

15 Taxa de crescimento relativo $\left(\mathrm{g} \mathrm{g}^{-1} \mathrm{dia}^{-1}\right)$ do cultivar de girassol $\mathrm{C}$ 11 , nas densidades de $2,3,4,5$ e 6 plantas por metro de linha, em época de semeadura safrinha.

16 Taxa de crescimento relativo $\left(\mathrm{g} \mathrm{g}^{-1} \mathrm{dia}^{-1}\right)$ do cultivar de girassol $\mathrm{M}$ 734 , nas densidades de $2,3,4,5$ e 6 plantas por metro de linha, em época de semeadura safrinha.

17 Taxa assimilatória líquida $\left(\mathrm{g} \mathrm{m}^{-2}\right.$ dia $^{-1}$ IAF) do cultivar de girassol C 11, nas densidades de 2, 3, 4, 5 e 6 plantas por metro de linha, em época de semeadura safrinha. 
18 Taxa assimilatória líquida $\left(\mathrm{g} \mathrm{m}^{-2} \mathrm{dia}^{-1} \mathrm{IAF}\right.$ ) do cultivar de girassol M 734 , nas densidades de 2, 3, 4, 5 e 6 plantas por metro de linha, em época de semeadura safrinha

19 Razão de área foliar $\left(\mathrm{m}^{2} \mathrm{~g}^{-1}\right)$ do cultivar de girassol $\mathrm{C} 11$, nas densidades de 2, 3, 4, 5 e 6 plantas por metro de linha, em época de semeadura safrinha.

20 Razão de área foliar $\left(\mathrm{m}^{2} \mathrm{~g}^{-1}\right)$ do cultivar de girassol $M 734$, nas densidades de 2, 3, 4, 5 e 6 plantas por metro de linha, em época de semeadura safrinha.

21 Número de folhas por planta de girassol dos cultivares $C 11$ e $M$ 734 , em função das densidades de plantas na linha, em época de semeadura safrinha

22 Diâmetro basal de haste $(\mathrm{cm})$ dos cultivares de girassol $\mathrm{C} 11$ e $\mathrm{M}$ 734 , em função da densidades de plantas na linha, em época de semeadura safrinha

23 Número de aquênios por capítulo dos cultivares de girassol C $11 \mathrm{e}$ M 734, em função da densidades de plantas na linha, em época de semeadura safrinha

24 Massa de mil aquênios dos cultivares de girassol C 11 e $M 734$, em função das densidades de plantas na linha, em época de semeadura safrinha 


\section{LISTA DE TABELAS}

Página

1 Características de fertilidade do solo da área experimental. Piracicaba, SP. 1999 ................................................................ 20

2 Principais características de alguns cultivares de girassol................ 22

3 Densidade de plantas na linha e respectivas populações por hectare.

4 Descrição dos estádios vegetativos do girassol................................. 24

5 Descrição dos estádios reprodutivos do girassol.............................. 25

6 Esquema da análise da variância individual................................... 31

7 Valores totais de radiação solar (RS), precipitação (P), precipitação acumulada $(\mathrm{Pa})$ e número de dias com chuva $(\mathrm{DC})$ e valores médios para temperaturas mínima (Tmin.), máxima (Tmáx.) e média (Tméd.), correspondentes a diferentes períodos fenológicos do girassol. Piracicaba, SP. 1999

8 Duração em dias após a emergência de algumas fases fenológicos para cultivares de girassol, manejados sob diferentes densidades de plantas, em época de semeadura safrinha.................................

9 Massa seca acumulada $\left(\mathrm{g} \mathrm{m}^{-2}\right)$ de cultivares de girassol no estádio $V_{12}$, manejados sob diferentes densidades de plantas, em época de semeadura safrinha. 
10 Massa seca acumulada $\left(\mathrm{g} \mathrm{m}^{-2}\right)$ de cultivares de girassol no estádio $V_{21}$, manejados sob diferentes densidades de plantas, em época de semeadura safrinha.

11 Massa seca acumulada $\left(\mathrm{g} \mathrm{m}^{-2}\right)$ de cultivares de girassol no estádio $R_{2}$, manejados sob diferentes densidades de plantas, em época de semeadura safrinha

12 Massa seca acumulada $\left(\mathrm{g} \mathrm{m}^{-2}\right)$ dos cultivares de girassol C 11 e M 734 , nos estádios $R_{4}$ e $R_{5.1}$ respectivamente, manejados sob diferentes densidades de plantas, em época de semeadura safrinha.

13 Massa seca acumulada $\left(\mathrm{g} \mathrm{m}^{-2}\right)$ dos cultivares de girassol C 11 e M 734 , nos estádios $R_{5.6}$ e $R_{5.8}$ respectivamente, manejados sob diferentes densidades de plantas, em época de semeadura safrinha.

14 Massa seca acumulada $\left(\mathrm{g} \mathrm{m}^{-2}\right)$ de cultivares de girassol no estádio $R_{6}$, manejados sob diferentes densidades de plantas, em época de semeadura safrinha

15 Massa seca acumulada $\left(\mathrm{g} \mathrm{m}^{-2}\right)$ dos cultivares de girassol C 11 e M 734 , nos estádios $R_{7}$ e $R_{8}$ respectivamente, manejados sob diferentes densidades de plantas, em época de semeadura safrinha.

16 Massa seca acumulada individualmente ( $\mathrm{g} \mathrm{planta}^{-1}$ ) e por unidade de área $\left(\mathrm{g} \mathrm{m}^{-2}\right)$ observados para cultivares de girassol, manejados sob diferentes densidades de plantas, em época de semeadura safrinha.

17 Índice de área foliar $\left(\mathrm{m}^{2} \mathrm{~m}^{-2}\right)$ de cultivares de girassol no estádio $V_{12}$, manejados sob diferentes densidades de plantas, em época de semeadura safrinha.

18 Índice de área foliar $\left(\mathrm{m}^{2} \mathrm{~m}^{-2}\right)$ de cultivares de girassol no estádio $V_{21}$, manejados sob diferentes densidades de plantas, em época de semeadura safrinha. 
19 Índice de área foliar $\left(\mathrm{m}^{2} \mathrm{~m}^{-2}\right)$ de cultivares de girassol no estádio $R_{2}$, manejados sob diferentes densidades de plantas, em época de semeadura safrinha

20 Índice de área foliar $\left(\mathrm{m}^{2} \mathrm{~m}^{-2}\right)$ dos cultivares de girassol $\mathrm{C} 11$ e M 734 , nos estádios $R_{4}$ e $R_{5.1}$ respectivamente, manejados sob diferentes densidades de plantas, em época de semeadura safrinha

21 Índice de área foliar $\left(\mathrm{m}^{2} \mathrm{~m}^{-2}\right)$ dos cultivares de girassol C 11 e M 734 , nos estádios $R_{5.6}$ e $R_{5.8}$ respectivamente, manejados sob diferentes densidades de plantas, em época de semeadura safrinha.

22 Índice de área foliar $\left(\mathrm{m}^{2} \mathrm{~m}^{-2}\right)$ de cultivares de girassol no estádio $R_{6}$, manejados sob diferentes densidades de plantas, em época de semeadura safrinha.

23 Índice de área foliar $\left(\mathrm{m}^{2} \mathrm{~m}^{-2}\right)$ dos cultivares de girassol $\mathrm{C} 11 \mathrm{e} \mathrm{M}$ 734, nos estádios $R_{7}$ a $R_{8}$ respectivamente, manejados sob diferentes densidades de plantas, em época de semeadura safrinha.

24 Valores mínimo e máximo para taxa de crescimento da cultura dos cultivares de girassol $\mathrm{C} 11$ e $\mathrm{M} 734$ e respectivo números de dias após a emergência (DAE) em que ocorreram, em função da densidades de plantas na linha, em época de semeadura safrinha.

25 Valores mínimo e máximo para taxa de crescimento relativo dos cultivares de girassol C 11 e M 734 e respectivo números de dias após a emergência (DAE) em que ocorreram, em função da densidades de plantas na linha, em época de semeadura safrinha.

26 Valores mínimo e máximo para taxa assimilatória líquida dos cultivares de girassol C 11 e M 734 e respectivo números de dias após a emergência (DAE) em que ocorreram, em função da densidades de plantas na linha, em época de semeadura safrinha. 
27 Valores mínimo e máximo para razão de área foliar dos cultivares de girassol C 11 e M 734 e respectivo números de dias após a emergência (DAE) em que ocorreram, em função da densidades de plantas na linha, em época de semeadura safrinha

28 Rendimento econômico (RE) e indice de colheita (IC) dos cultivares de girassol, manejados sob diferentes densidades de plantas, em época de semeadura safrinha

29 Número de folhas por planta de cultivares de girassol, manejados sob diferentes densidades de plantas, em época de semeadura safrinha.

30 Altura final de planta $(\mathrm{cm})$ dos cultivares de girassol, manejados sob diferentes densidades de plantas, em época de semeadura safrinha

31 Diâmetro basal de haste $(\mathrm{cm})$ de cultivares de girassol, manejados sob diferentes densidades de plantas, em época de semeadura safrinha.

32 Diâmetro de capítulo $(\mathrm{cm})$ de cultivares de girassol, manejados sob diferentes densidades de plantas, em época de semeadura safrinha.

33 Número de aquênios por capítulo de cultivares de girassol, manejados sob diferentes densidades de plantas, em época de semeadura safrinha.

34 Massa de 1000 aquênios (g) de cultivares de girassol, manejados sob diferentes densidades de plantas, em época de semeadura safrinha.

35 Rendimento em aquênios $\left(\mathrm{kg} \mathrm{ha}^{-1}\right)$ de cultivares de girassol, manejados sob diferentes densidades de plantas, em época de semeadura safrinha 
36 Estimativa dos coeficientes de correlação simples ( $r$ ) entre características agronômicas com o rendimento em aquênios para os cultivares de girassol C 11 e M 734, manejados sob diferentes densidades de plantas, em época de semeadura safrinha.

37 Estimativa dos coeficientes de correlação simples ( $r$ ) entre a matéria seca e índice de área foliar e os componentes de rendimento para os cultivares de girassol C 11 e M 734, manejados sob diferentes densidades de plantas, em época de semeadura safrinha. 


\title{
ANÁLISE DE CRESCIMENTO E PRODUTIVIDADE AGRÍCOLA DE GIRASSOL CONDUZIDO NA SAFRINHA EM CINCO DENSIDADES DE PLANTAS
}

\author{
Autora: CRISTIANE DE ARAUJO MONTEIRO \\ Orientador: Prof. Dr. GIL MIGUEL DE SOUSA CÂMARA
}

\section{RESUMO}

Realizou-se análise de crescimento e rendimento de cultivares de girassol (Helianthus annuus L.), semeado em época de semeadura safrinha, manejado sob cinco densidades de plantas $\left(2,3,4,5\right.$ e 6 plantas $\left.\mathrm{m}^{-1}\right)$. O experimento foi conduzido com 10 tratamentos ( 2 cultivares $\times 5$ densidades) repetidos 3 vezes, delineado em blocos ao acaso. A massa seca total e o índice de área foliar foram coletados a intervalos regulares de 14 dias. A massa seca total foi determinada em 10 plantas de girassol. O índice de área foliar foi determinado utilizando-se o analisador de dossel Li-cor ${ }^{\circledR}$, modelo LAl-2000. Os índices fisiológicos, taxa de crescimento da cultura, taxa de crescimento relativo, taxa de assimilação líquida e razão de área foliar, foram então determinados através das funções ajustadas para massa seca total e índice de área foliar. Adicionalmente, foram avaliadas as seguintes características: número de folhas, altura final de planta, diâmetro basal de haste, diâmetro de capítulo, número de aquênios por capítulos, massa de 1.000 aquênios e rendimento de aquênios. Os resultados permitiram concluir que: a) a produção 
de massa seca é influenciada pelo fator genótipo; b) a densidade de 6 plantas $\mathrm{m}^{-1}$ proporciona maior produção de massa seca total; c) o índice de área foliar não é influenciado pelos fatores densidade de plantas e genótipo; d) $\circ n^{\circ}$ de aquênios por capítulo é o componente da produção da planta mais importante para a determinação da produtividade agrícola de girassol; e) o aumento na densidade de plantio não diminui o $n^{\circ}$ de folhas, o diâmetro de haste, $0 n^{\circ}$ de aquênios por capitulo e a massa de aquênios de girassol; f) a diminuição do $n^{\circ}$ de aquênios por capitulo e da massa de aquênios, em razão do aumento da densidade de plantas na linha, é compensada pelo maior $n^{0}$ de plantas por unidade de área, não afetando a produtividade agrícola de girassol; g) Cargill 11 apresenta maior produtividade agrícola que Morgan 734, porém essa diferença foi devido ao efeito de baixas temperaturas na antese, que afetou principalmente esse último cultivar. 


\title{
GROWTH AND YIELD ANALYSIS OF SUNFLOWER IN THE LATE SOWING SEASON UNDER FIVE PLANTING DENSITIES
}

\author{
Author: CRISTIANE DE ARAUJO MONTEIRO \\ Adviser: Prof. Dr. GIL MIGUEL DE SOUSA CÂMARA
}

\section{SUMMARY}

The growth and yield analyses of the sunflower cultivars were studied in the late sowing, under five planting densities $\left(2,3,4,5\right.$ e 6 plants $\left.\mathrm{m}^{-1}\right)$. The experiment was carried out with ten treatments ( 2 genotype $\times 5$ plant densities) and three replications in randomized block design. The total dry matter and leaf area index were assessed every 14 days. The total dry matter was sampled in 10 plants. The leaf area index was estimated with the plant canopy analyzer Licor®, LAI-2000. The physiological indexes, crop growth rate, relative growth rate, net assimilation rate and leaf area rate were estimated as functions of the total dry matter and leaf area index. Also, the number of leaves, final plant height, stem girth, head girth, seed number per head, weight of 1.000 seeds and seed yield were measured. The results drive the following conclusions: a) the dry matter production is affected by genotype; $b$ ) the plant density of 6 plants $\mathrm{m}^{-1}$ presented the highest dry matter production; $c$ ) the leaf area index wasn't affect by plant density and genotype; d) the number of seeds per head is most important yield component to determine productivity; e) the increment in the plant density reduced the number of leaves, stem girth, seed number per head 
and weight of 1.000 seeds; f) the decrease in the seed number per head and weight of 1.000 seeds with increase plant density was compensate by higher number of plants per area, not affecting seed yield; g) Cargill 11 produced higher seed yield than Morgan 734, although this difference was due to low temperatures during anthesis affecting mainly the latest. 


\section{INTRODUÇÃO}

O girassol (Helianthus annuus L.) é uma planta rica em óleo e proteína, originária da América do Norte, mais precisamente, das regiões correspondentes ao Norte do México e ao Estado de Nebraska, nos Estados Unidos.

Apresenta características agronômicas importantes como, maior resistência à seca, frio e calor, em relação à maioria das espécies normalmente cultivadas no Brasil; ampla adaptabilidade às diferentes condições edafoclimáticas, tendo o seu rendimento pouco influenciado pela latitude, e altitude.

Atualmente, com o crescimento do uso de sistemas de produção agrícola, fundamentados em rotação de culturas, o girassol vem adquirindo importância, devido a sua ampla capacidade de adaptação a diferentes épocas de semeadura. A sua implantação pode ocorrer em época de semeadura safrinha, em função da sua tolerância às condições climáticas adversas de outono, entrando após o milho ou soja. Nos Estados do Sul, podendo suceder o milho safrinha, a aveia e o trigo, ou entrar em rotação com a cana-de-açúcar nas áreas de reformas canavieiras, principalmente no Estado de São Paulo, e também como planta para produção de silagem em Minas Gerais, Paraná, Rio Grande do Sul e Mato Grosso do Sul.

Outro aspecto favorável á utilização da cultura do girassol na safrinha, refere-se à ocupação da área agrícola, com outra cultura rentável dentro do mesmo ano agrícola, sem prejuízos ao ciclo normal da cultura de verão, com as vantagens técnicas de permitir variabilidade no volume de solo explorado, na reciclagem e aproveitamento dos nutrientes residuais da adubação feita para a 
cultura de verão, redução da infestação de plantas daninhas e favorecimento do sistema conservacionista do solo agrícola.

$\mathrm{Na}$ safra de 1998/99, segundo dados da Companhia Nacional de Abastecimento $^{1}$ e da Secretaria de Comércio Exterior ${ }^{1}$, a cultura do girassol no Brasil produziu 49 mil toneladas de grãos e 10 mil toneladas de óleo, sendo que para atender a demanda nacional de 68 mil toneladas de óleo, foram importadas 58 mil toneladas. Para a safra de 1999/00, a produção de óleo chegou a 14 mil toneladas, sendo ainda insuficiente para atender ao consumo nacional de 69 mil toneladas de óleo, tornando-se necessário a importação de 55 mil toneladas, da maior parte, oriunda da Argentina.

Cultura emergente no Brasil, ainda vem apresentando alguns problemas de natureza técnica, como por exemplo, a determinação da melhor população de plantas de girassol, visando altos rendimentos. Na literatura nacional, poucos são os trabalhos relacionados a esse aspecto agronômico e as características fisiológicas associadas ao crescimento dessa oleaginosa, principalmente em época de semeadura safrinha.

A análise de crescimento pode ser utilizada para interpretar e quantificar a produção vegetal, mediante alterações no manejo cultural, como a população de plantas, mediante o uso de modelos e fórmulas matemáticas ajustadas aos dados primários de massa de matéria seca e área foliar, requisitos básicos na determinação de diversos índices fisiológicos.

Objetivou-se avaliar, por meio da análise de crescimento e rendimento, o desempenho vegetativo e produtivo de dois cultivares de girassol, manejados sob diferentes densidades de plantas em época de safrinha, considerando-se que :

a) Existe pelo menos uma combinação "cultivar $x$ densidade" ideal para o rendimento em aquênios em época de safrinha.

\footnotetext{
${ }^{1}$ Fonte: Associação Brasileira de Óleos Vegetais (2000)
} 
b) A compensação do rendimento do girassol sob diferentes densidades populacionais, é devida à alterações no crescimento da área foliar das plantas. 


\section{REVISÃO DE LITERATURA}

\subsection{Fisiologia do girassol}

A planta de girassol apresenta o fenômeno do heliotropismo, o que faz com que as folhas jovens e o botão floral acompanhem o movimento relativo do sol, do nascente pela manhã para poente à tarde, contribuindo para aumento de 10 a $20 \%$ na interceptação de luz. $\mathrm{Na}$ iniciação da antese $\left(R_{5.1}\right)$, essa resposta cessa e os capitulos ficam orientados em uma única direção, predominantemente para o leste, até a maturidade fisiológica (Vrânceanu, 1977; Blamey et al., 1997).

Entre os cultivares de girassol existe variabilidade na resposta fotoperiódica, embora a maioria responda ao fotoperiodo longo ou neutro, entre a emergência até iniciação floral (Connor e Hall, 1997). A interceptação da radiação solar atinge o máximo durante o florescimento, mas segundo Rawson e Constable (1980), decresce durante o desenvolvimento reprodutivo devido à rápida senescência das folhas, diminuindo sua capacidade fotossintética.

Adapta-se bem a temperaturas entre 12 a $30^{\circ} \mathrm{C}$, com temperaturas ótimas para o crescimento entre 27 e $28^{\circ} \mathrm{C}$, e temperatura base em torno de $4^{\circ} \mathrm{C}$ (Carter, 1978; Unger, 1990; Cetiom, 1992).

A susceptibilidade a baixas temperaturas varia com o estádio de desenvolvimento. Plantas até o estádio $V_{6}$ ( 6 folhas) toleram temperaturas de até $-5^{\circ} \mathrm{C}$. A partir desse momento, ocorrem injúrias à gema apical, resultando em plantas ramificadas com baixo potencial produtivo. Particularmente, nos estádios $R_{4}$ e $R_{5}$ (antese), quando baixas temperaturas coincidem com a 
polinização, os grãos de pólen são destruídos, resultando em abortamento de flores e aquênios mal formados (Blamey et al., 1997).

A temperatura mínima no subperiodo florescimento - maturação, correlaciona-se com os ácidos oléico e linoléico, atribuídos à qualidade do óleo de girassol, que apresentam antagonismo entre si. Com aumento na temperatura mínima, ocorre redução na percentagem do ácido linoléico e aumento do ácido oléico (Ungaro et al., 1997).

Quando semeado em regiões secas, o consumo de água pelo girassol varia de 500 a $700 \mathrm{~mm}$, enquanto que para regiões mais úmidas, os valores situam-se entre 300 a $500 \mathrm{~mm}$, sendo influenciado pelas condições climáticas, duração do ciclo e manejo da cultura (Unger, 1990).

O girassol apresenta baixa eficiência do uso da água, para cada litro de água consumido produz menos de dois gramas de matéria seca, atribuída à baixa resistência à passagem da água pelas raizes, hastes e estômatos. $\mathrm{A}$ eficiência do uso da água, pode ser expressa pela relação entre a matéria seca total produzida/quantidade de água consumida ou ainda pela relação fotossintese/transpiração. Em condições de déficit hídrico, observa-se incremento na eficiência de uso da água, em torno de 20 a 50\%, devido a redução comparativamente menor ocorrida na fotossíntese em relação à perda de água por transpiração (Gómez-Arnau, 1988; Cetiom, 1992).

Unger (1990), estudando a resposta da planta de girassol a condições de déficit hidrico, observou rendimentos relativamente altos, como resultado do aumento na profundidade do sistema radicular e maior habilidade das raízes para extrair água á baixos potenciais hídricos do solo.

Em experimento realizado por Cox e Jolliff (1987), evidenciou-se a extração de água pelo girassol a profundidades entre 0,9 a $1,8 \mathrm{~m}$, o que 
propiciou menor restrição hídrica, mesmo sob condições severas de seca. Para se adaptar as essas condições, a cultura reduziu a área foliar e extraiu água em maior profundidade no perfil.

A expansão foliar, segundo Cox e Jolliff (1986), é a característica do crescimento mais sensível ao déficit hídrico, refletindo também sobre o índice de área foliar. Entre os componentes do rendimento, o número de aquênios por capítulo foi o mais afetado. O estresse hídrico também pode provocar reduções no tamanho e massa de aquênios e, no conteúdo de óleo (Unger, 1990).

Segundo Gómez-Arnau (1988), o girassol apesar de ser planta $C_{3}$, apresenta elevado potencial fotossintético (40 a $50 \mathrm{mg} \mathrm{CO} \mathrm{dm}^{-2} \mathrm{~h}^{-1}$ ), comparável a plantas $\mathrm{C}_{4}$, como milho e sorgo $\left(60\right.$ a $\left.75 \mathrm{mg} \mathrm{CO}_{2} \mathrm{dm}^{-2} \mathrm{~h}^{-1}\right)$. Alguns fatores, como alta densidade de estômatos distribuídos em ambas as faces das folhas (com densidade maior na parte inferior), alta condutância estomatal, elevada quantidade e alta atividade específica da enzima rubisco, além de eficiência no transporte de elétrons nos cloroplastos, são responsáveis pela alta fotossintese líquida do girassol (Connor e Sadras, 1992).

No entanto, a cultura não é eficiente na partição de assimilados para o desenvolvimento de aquênios. Isto pode ser evidenciado através do índice de colheita, em torno de 0,20 a 0,30 , menor ao apresentado por outras culturas, como por exemplo, o trigo $(0,5$ a 0,6) (English et al., 1979; Blanchet et al., 1982). Isso porque, segundo Connor e Hall (1997), a produção de aquênios exige maior custo energético $\left(1,61 \mathrm{~g} \mathrm{CO}_{2} / \mathrm{g}\right.$ lipídios), devido ao seu maior conteúdo de óleo em relação aos cereais $\left(0,12 \mathrm{~g} \mathrm{CO}_{2} / \mathrm{g}\right.$ carboidratos).

Para Connor e Sadras (1992), os períodos considerados importantes na formação do rendimento de girassol são: a) iniciação floral até o início da antese, onde são determinados o número de flores (diferenciação $e$ sobrevivência) e o número potencial de aquênios; b) início até o fim da antese, 
quando o número de aquênios é determinado a partir dos floretes disponiveis e, por sua capacidade de desenvolver uma semente e, c) final da antese até a maturidade fisiológica, quando as condições de crescimento determinam a extensão do período de enchimento de aquênios.

\section{2 Época de semeadura}

São poucos os trabalhos científicos com girassol, que especificam a época de semeadura denominada "safrinha", compreendida como a época de semeadura disponivel após a colheita da safra de verão, desde que haja condições ambientais de radiação solar, temperatura e umidade, favoráveis à germinação das sementes, emergência e estabelecimento das plantas, e que garantam o desenvolvimento destas até a colheita.

De acordo com Gonçalves et al. (1981), o girassol pode ser semeado em sucessão a outras culturas como soja precoce, arroz, amendoim ou milho, devido, principalmente, a sua tolerância à seca por apresentar sistema radicular profundo. Dessa forma, a época de semeadura depende da colheita da cultura anterior, o que ocorre normalmente no período de 15 de fevereiro a 30 de março.

Campbell e Athayde (1988) ao estudarem o comportamento de genótipos de girassol em cinco datas de semeadura, observaram que com o atraso destas, ocorreram decréscimos no periodo da emergência ao florescimento, altura de planta, número de folhas, diâmetro de haste, diâmetro de capitulo, massa de matéria seca do capitulo e rendimentos de aquênios. Como fator causador desses decréscimos, os autores apontam a redução da umidade do solo, devido à menor precipitação pluvial nas semeaduras tardias, obtendo como valores médios de rendimento, $2.942 \mathrm{~kg} \mathrm{ha}^{-1}$ para 20 de janeiro e, $809 \mathrm{~kg}$ ha ${ }^{-1}$ para 05 de abril. 
Para Silva (1990), nos estados do Mato Grosso, Mato Grosso do Sul, Goiás e estados do Sul, a época de semeadura é distribuída em dois períodos: de outubro até dezembro, para a cultura de verăo e, de janeiro a fevereiro, como cultura de safrinha. Nas semeaduras de verão, a produtividade agrícola de girassol pode alcançar valores de 1.800 a $3.000 \mathrm{~kg} \mathrm{ha}^{-1}$ devido às melhores condições de precipitação e radiação solar, apesar da maior ocorrência de pragas e doenças e do maior consumo de insumos. No entanto, ocorre liberação da área mais rapidamente para outras culturas. Na semeadura de safrinha, aproveita-se o resíduo de adubos e há menor ocorrência de plantas daninhas e pragas, porém, com maior risco de ocorrência de geadas no florescimento e na formação dos aquênios. $\dot{A}$ medida que se atrasa a semeadura, a partir de janeiro, os rendimentos decrescem atingindo valores de 800 a $1.800 \mathrm{~kg} \mathrm{ha}^{-1}$, em função das condições de menor luminosidade.

Silveira et al. (1990) utilizando quatro cultivares, semeados em diferentes datas de semeadura, de agosto a janeiro, observaram que a semeadura precoce (final do inverno e início da primavera) contribui para o alongamento do ciclo vegetativo proporcionando condições para maior rendimentos de aquênios e óleo em relação à semeadura tardia (final da primavera e início do verão).

Sarder et al. (1991a), estudando plantas de girassol em nove diferentes épocas de semeadura ( 15 de janeiro até 31 de março), observaram decréscimos no diâmetro de capitulo e rendimentos de aquênios, com o atraso na época de semeadura. Em função desses resultados, os autores recomendam semear o mais cedo possível, dentro da época denominada "seca".

\subsection{População de plantas}

Atualmente, a cultura do girassol avança para os estados do Brasil Central (baixas latitudes) fundamentada em novos genótipos, alguns 
importados diretamente da Argentina, havendo, portanto a necessidade de ajustar melhor a população de plantas para altos rendimentos (Castiglioni ${ }^{2}$, 1996).

A Empresa Brasileira de Pesquisa Agropecuária (EMBRAPA) (1983) afirma que um dos principais fatores que contribuem para o sucesso da cultura do girassol é o estabelecimento de uma população de plantas adequada e uniformemente distribuida. Em casos de população elevada, pode ocorrer o estiolamento das plantas devido à competição pela luz, promovendo o seu acamamento, causando diminuição da ventilação e conseqüente aumento da incidência de doenças, refletindo negativamente sobre o diâmetro de capitulo, e, portanto o rendimento.

A planta de girassol possui grande capacidade de adaptação a distintas condições ambientais, observando-se maior amplitude no intervalo de densidades de plantas, dentro do qual os rendimentos se mantêm relativamente constantes (Cardinali et al., 1985).

Segundo Gonçalves et al. (1981), a população ótima de plantas varia de acordo com o porte, vigor, precocidade da variedade ou hibrido, considerando como ideal a população de plantas por hectare dentro da faixa de 30.000 (cultivares de ciclo longo) a 60.000 (cultivares de ciclo precoce).

A população de plantas por unidade de área, é resultante da combinação entre densidade de plantas na linha e espaçamento entrelinhas.

Nakagawa et al. (1989) estudando plantas do cultivar IAC - Anhandy, cultivadas sob seis espaçamentos entre linhas, observaram que os maiores valores para diâmetro de capítulo e massa de aquênios por capítulo foram obtidos com o espaçamento de $0,8 \mathrm{~m}$, enquanto o rendimentos de aquênios foi maior com o espaçamento de $0,7 \mathrm{~m}$.

${ }^{2}$ CASTIGLIONI, V. B. R. (EMBRAPA. Centro Nacional de Pesquisa de Soja, Londrina). Comunicação pessoal, 1998. 
Estudos realizados por Rajput et al. (1994) evidenciaram que o espaçamento médio $(50 \times 20 \mathrm{~cm})$ permitiu incrementos significativos no teor de proteína e no rendimentos de aquênios, devido ao máximo diâmetro de capitulo e massa de 1000 aquênios, enquanto que o teor de óleo foi máximo em espaçamento mais fechado $(40 \times 20 \mathrm{~cm})$.

Ungaro et al. (1996) estudando o cultivar IAC-Anhandy cultivado em outubro e fevereiro, sob três arranjos de espaçamento $(100 \times 40 ; 50 \times 40$ e $50 \times$ $20 \mathrm{~cm}$ ) e sob diferentes modalidades de capina, observaram na época da seca (fevereiro), o espaçamento entre plantas teve efeito significativo sobre o diâmetro de capítulo, sendo que o espaçamento de $40 \mathrm{~cm}$ apresentou maior produção de aquênios em qualquer modalidade de capina $e$, que os espaçamentos mais abertos apresentaram maior diâmetro de capitulo e menor altura de planta.

Cardinali et al. (1985) avaliaram o desempenho de dois híbridos de girassol, Dekalb G-98 (ciclo curto) e Cargill Super 500 (ciclo longo), nas diferentes densidades de semeadura $\left(10,20,30,40\right.$ e 50 mil plantas ha $\left.{ }^{-1}\right)$ e constataram que o rendimento biológico por planta diminuiu com aumento da densidade, assim como a massa seca de seus componentes (haste, folhas, receptáculo e aquênios), embora mantivessem uma proporção constante, evidenciando a plasticidade da planta de girassol. O índice de área foliar respondeu positivamente à densidade, o que não ocorreu com a área foliar por planta, que apresentou redução devido ao murchamento e à diminuição no tamanho individual das folhas. Quanto aos componentes de rendimento, os autores observaram que tanto a massa de 1000 aquênios como o número de aquênios por capítulo decresceram com o aumento da população na área, semelhante aos resultados obtidos por Miller et al. (1984), Silva e Nepomuceno (1991) e Carvalho et al. (1991-95). Ainda, Cardinali et al. (1985) afirmam que 
essas reduções foram compensadas com o aumento no número de plantas, permitindo manter o rendimento econômico constante entre 20.000 a 30.000 plantas ha $\mathrm{a}^{-1}$.

O efeito da densidade de semeadura sobre o crescimento e rendimento do híbrido de girassol $\$ 458$ foi estudada por Aguirrezábal et al. (1987). Os autores observaram que na menor densidade ( 35.700 plantas ha $^{-1}$ ), a máxima

superfície foliar foi atingida 7 dias depois da floração, atribuída à distância entre as plantas e à expansão foliar, que não foi limitada pelo autosombreamento.

Por outro lado, de acordo com Hiroi e Monsoi $(1966)^{3}$, citados por Aguirrezábal et al. (1987), em maiores densidades, o autosombreamento influiu para que a máxima área foliar fosse atingida antes, na pré-floração. $O$ estabelecimento da competição intraespecífica contribuiu para redução na área foliar por planta, do seu valor máximo até a maturação fisiológica, em $55 \%$ para 35.700 plantas ha ${ }^{-1}$ e $79 \%$ para 286.000 plantas $a^{-1}$, refletindo principalmente no rendimento individual das plantas.

Silva e Nepomuceno (1991), avaliando o cultivar Contisol 711 sob três espaçamentos $(0,4,0,7$ e $1,0 \mathrm{~m})$ e três densidades $(30,50$ e 70 mil plantas ha${ }^{1}$ ), observaram que o rendimento de aquênios e o teor de óleo, responderam positivamente à densidade, devido ao aumento no número de capitulos por unidade de área. Sarder et al. (1991b) também comprovaram o efeito significativo sobre o rendimentos de aquênios quando as densidades variaram de 37.500 a 50.000 plantas ha ${ }^{-1}$.

Carvalho et al. (1991-95), estudando os efeitos de épocas de semeadura (18 de fevereiro, 16 de março e 14 de abril) e densidades de plantio $(2,5,5,0$ e 7,5 plantas $\mathrm{m}^{-2}$ ) sobre o rendimento da variedade de girassol Florasol,

\footnotetext{
${ }^{3} \mathrm{HIROI}, \mathrm{T}$; MONSOI, M. Dry matter economy of Helianthus annuus comunities grown at varying densities and light intensities. Journal of Faculty of Science of University of Tokyo, v. 9, p. $241-285,1966$.
} 
observaram que o aumento da população de plantas refletiu positivamente sobre o índice de área foliar (IAF) durante o florescimento, e sobre a duração de área foliar (DAF) durante todo o ciclo da cultura. Também encontraram correlações significativas entre o rendimento e os seus componentes, massa de 1000 aquênios $(0,49)$, número de aquênios $\mathrm{m}^{-2}(0,92)$ e $\operatorname{DAF}(0,88)$, desde a emergência até a maturação. Devido às reduções apresentadas na massa de 1000 aquênios e no número de aquênios por capítulo, os autores não encontraram efeito significativo da população sobre o rendimento, resultados esses compativeis aos descritos por Miller et al. (1984), na avaliação dos hibridos NK 212 e CW 894, em diferentes niveis populacionais $(28.700,43.800$, 57.900 e 70.700 plantas ha $^{-1}$ ).

Ao estudarem duas cultivares de girassol (Contisol 711 e GR-10) em quatro populações de plantas $\left(30,50,70\right.$ e 90 mil plantas ha $\left.{ }^{-1}\right)$, Rizzardi e Silva (1992), concluíram que a elevação na densidade de plantio reduziu o rendimentos de aquênios, e conseqüentemente o rendimento de óleo para GR10 (ciclo longo), o que não aconteceu para Contisol 711 (ciclo precoce), que apresentou aumento de $26 \%$ no teor de óleo em relação à densidade mais baixa.

Sarmah et al. (1992), estudando diferentes densidades de plantas, observaram que a redução de 111.111 para 49.382 plantas por hectare, refletiu em aumento na área foliar e no acúmulo de massa de matéria seca por planta. $O$ rendimentos de aquênios também respondeu ao fator densidade, atingindo valor máximo com 74.074 plantas $\mathrm{ha}^{-1}$. Valores significativamente inferiores foram encontrados tanto na densidade mais alta (111.111 plantas ha ${ }^{-1}$ ) como na densidade mais baixa (49.382 plantas $\mathrm{ha}^{-1}$ ), atribuídos ao aumento da competição intraespecífica e ao menor número de plantas ha ${ }^{-1}$, para a maior e menor população de plantas, respectivamente. 
Almeida e Silva (1993), ao avaliarem os efeitos de duas épocas de semeadura (27/07 e 19/09), em quatro densidades de plantio $(30,45,60$ e 75 mil plantas ha-1) do cultivar Contisol, na presença e ausência de adubação. $\mathrm{Na}$ segunda época de semeadura, ocorreu redução mais acentuada no número de aquênios por capítulo com aumento da densidade de plantas. Para a massa de 1000 aquênios, essa redução foi superior na primeira época atribuída ao maior período de enchimento de aquênios. A densidade de plantio teve efeito negativo mais acentuado na massa de aquênios do que no número de aquênios por capítulo, não refletindo no rendimento. O teor de óleo, por sua vez, aumentou em função da densidade de plantas, na primeira época de semeadura.

Rizzardi e Silva (1993) não observaram diferença no rendimentos de aquênios para os cultivares Contisol 711 (ciclo precoce), DK 180 e GR-10 (ciclos longo), semeados em duas épocas (28/07 e 18/09), com aumento da densidade de plantas $\left(30,50,70\right.$ e 90 mil plantas ha $\left.^{-1}\right)$. Entretanto, cultivares de ciclo longo apresentaram maior redução no rendimento com o aumento da densidade de semeadura.

Silva et al. (1995) avaliando densidades populacionais (25.000 a 75.000; 25.000 a 50.000 , e 30.000 a 90.000 plantas ha $^{-1}$ ) para cultivares de girassol de ciclo longo (Contisol, DK 180 e GR-10) e ciclo precoce (Contisol 711 e GR-16), concluíram que os cultivares de ciclo precoce obtiveram os maiores rendimentos de aquênios sob densidades mais elevadas do que cultivares de ciclo longo, por possuírem características (menor altura de planta e massa vegetativa) que determinaram menor sombreamento e portanto melhor aproveitamento da luz.

Visando estudar o efeito da população de plantas $(0,5,2,0,5,0$ e 10 plantas $\mathrm{m}^{-2}$ ) sobre a partiçăo de matéria seca e o rendimento de quatro híbridos de girassol (SW 101, Arbung E353, Sungro 385 e S530), Villalobos et al. (1994), verificaram redução na partição de matéria seca para as folhas e aumento na 
partição para o capitulo com aumento da densidade de plantio. Villalobos et al. (1996) também observaram decréscimo na partição de assimilados para as folhas e incremento para as hastes e capítulo, quando a densidade de plantas aumentou de 0,5 para 10 plantas $\mathrm{m}^{-2}$. Esses resultados suportam a hipótese de que o capítulo tem prioridade na distribuição de assimilados entre os órgãos (Villalobos et al. 1992). Ainda, segundo Villalobos et al. (1994), o rendimentos de aquênios respondeu positivamente à densidade de semeadura, até atingir $4,5 \mathrm{t} \mathrm{ha}^{-1}$, atribuído à alta proporção de aquênios cheios e à taxa de enchimento, que compensaram o menor número de aquênios.

Andrade (1995), ao avaliar os efeitos da densidade de semeadura $(3,7$ e 6,7 plantas $\mathrm{m}^{-2}$ ) sobre o crescimento e rendimento do hibrido de girassol Dekalb $\mathrm{G} 100$, constatou que a redução na densidade de 6,7 para 3,7 plantas $\mathrm{m}^{-2}$ refletiu em decréscimo no número de aquênios cheios de 8.800 para $7.500 \mathrm{~m}^{-2}$ e acréscimo no peso dos aquênios em $26 \%$, mas o rendimentos de aquênios para as duas densidades não diferiram. Ainda, segundo esse autor, baixas densidades limitam o rendimento em ambientes de altos rendimentos, porque $o$ maior número de aquênios por capítulo e maior peso de aquênios não compensam completamente o menor número de capítulos por hectare.

\subsection{Análise de crescimento da planta de girassol}

A produção econômica de um cultivar é o somatório de todas as interações planta - ambiente. Para se compreender melhor a natureza dos seus controles internos, são necessárias medidas mais detalhadas que apenas a produção final (Machado, 1982).

A análise quantitativa de crescimento é o primeiro passo para a análise da produção vegetal, que requer como informações, a quantificação de material vegetal presente em toda a planta e em suas partes, e o tamanho do aparelho fotossintetizante (área foliar), obtidos em intervalos de tempo ao longo do ciclo 
da planta. Assim, obtém-se o acompanhamento da dinâmica da produção fotossintética efetiva, é dada pelo balanço entre fotossíntese, respiração e perdas devidas à senescência de tecidos e órgãos (Pereira e Machado, 1987; Machado, 1982).

A curva hipotética de crescimento vegetal, revela três fases distintas: i) Fase I, caracterizada por lento crescimento, quando a planta depende das reservas da semente para a produção dos órgãos que compõem a plântula; ii) Fase II, ocorre o desenvolvimento do sistema radicular e a emergência das folhas, apresentando rápido crescimento devido à retirada de água e nutrientes do substrato e, também à sua atividade fotossintética e; iii) Fase III, a planta entra em senescência com paralisação na produção de matéria orgânica e aumento da respiração em relação à fotossintese (Lucchesi, 1984; Magalhães, 1985; Felippe, 1985).

A determinação da área foliar é importante, porque as folhas são responsáveis pela captação da energia solar e pela produção de matéria orgânica através da fotossíntese. Se a superfície foliar e a variação da massa seca da planta são conhecidas, durante certo período de tempo, torna-se possivel avaliar a eficiência das folhas e a sua contribuição para o crescimento da planta.

Para Kvet et al., (1971) ${ }^{4}$ citados por Pereira e Machado (1987), a análise de crescimento pode ser usada para pesquisar a adaptação ecológica de culturas a novos ambientes, estudar a competição entre espécies, avaliar os efeitos de manejo e tratos culturais, e para identificar a capacidade produtiva de diferentes genótipos.

Segundo Lucchesi (1984) a análise de crescimento tem como objetivo, avaliar a contribuição dos diferentes órgãos para o crescimento das plantas,

\footnotetext{
${ }^{4}$ KVET, J.; ONDOK, J. P.; NECAS, J.; JARVIS, P. G. Methods of growth analysis. In: SESTAK, Z.; CATSKY, J.; JARVIS, P. G., (Ed.) Plant photosynthetic production - manual of methods. The Hague: W. Junk, 1971. p. 343-384.
} 
através da quantificação da produção vegetal, obtida por modelos matemáticos, sem a necessidade de laboratórios ou equipamentos sofisticados.

A eficiência do crescimento e a habilidade de adaptação das plantas às condições ambientais podem ser conhecidas a partir do estudo das interações entre os fatores do ambiente e índices fisiológicos da planta. Esses índices fisiológicos são: índice de área foliar (IAF), taxa de crescimento da cultura (TCC), taxa de crescimento relativo (TCR), taxa assimilatória líquida (TAL) e razão de área foliar (RAF), estimados a partir do conhecimento da variação temporal da área foliar e da massa de matéria seca total (Machado, 1982; Pereira e Machado, 1987; Peixoto, 1998).

Segundo Pereira e Machado (1987), a metodologia clássica de análise de crescimento permite apenas a estimativa de valores médios no intervalo entre duas amostragens. Para tanto, podem ser utilizadas funções matemáticas empíricas ajustadas aos dados primários de massa de matéria seca e área foliar, sendo os índices fisiológicos obtidos a partir dessas funções.

Ungaro et al. (1985), visando avaliar o desenvolvimento do girassol (cv. Anhandy), em duas épocas de semeadura, verão (11/10) e inverno (30/03), verificaram que as folhas atingiram a máxima quantidade de assimilados no

florescimento, com pequeno decréscimo logo após, provavelmente devido ao dreno para os aquênios. Por sua vez, as hastes continuaram a crescer após o florescimento, enquanto que os capítulos apresentaram acúmulo de massa seca até próximo à maturidade fisiológica. As taxas de crescimento relativo e assimilatória líquida foram máximas no início do período vegetativo. No entanto após o florescimento, foi observado decréscimo na taxa assimilatória líquida, principalmente no cultivo de inverno, em função da senescência precoce das folhas. No cultivo de verão, decréscimos nas taxas de crescimento relativo e assimilatória liquida foram atribuidas ao aumento do 
autosombreamento. A relação entre rendimentos de aquênios e a massa de matéria seca total foi de 0,29 no verão e, de 0,19 no inverno.

A análise do balanço de carbono realizada por Hall et al. (1990), mostrou que os assimilados fixados antes da antese, e armazenados principalmente nas hastes e receptáculos, contribuíram com importante proporção (15 e 27\% em culturas irrigadas e submetidas a estresse, respectivamente) do total de assimilados transferidos para os aquênios. Para Connor e Hall (1997), após a antese, o capítulo primeiramente e, depois os aquênios, tornam-se os drenos preferenciais pelos assimilados.

Os parâmetros da análise de crescimento em quatro variedades de girassol, duas de ciclo médio (Peredovick e Talinay) e duas de ciclo precoce (Victoria e Cernianka), foram estudados por Pérez Nieto et al. (1992). Constatou-se que a taxa assimilatória líquida foi relativamente alta no início do ciclo, sendo constante nos primeiros 30 dias e decaindo rapidamente após de 50 DAS, desempenho semelhante foi apresentado pela taxa de crescimento relativo. Os autores ainda observaram que, as melhores correlações entre a taxa relativa de crescimento e rendimento em óleo $(-0,97)$, taxa assimilatória líquida e proporção de ácido oléico $(0,95)$, taxa relativa de área foliar e proporção de ácido oléico $(-0,96)$ e taxa assimilatória líquida e rendimento de aquênios $(0,71)$, ocorreram no aparecimento do botão floral.

Jaafar et al. (1993), avaliando o desenvolvimento de plantas de girassol (Triumph 585) observaram valores máximos de índice de área foliar $(4,36)$, massa seca de folhas, hastes, capitulos e parte aérea, alcançados respectivamente, no final do período de abertura do botão floral (estádio $R_{4.7}$ ), no final do florescimento $\left(R_{5.9}\right)$, quando o capítulo se apresentava amarelo com brácteas ainda verdes $\left(R_{7.8}\right)$, na maturidade fisiológica $\left(R_{9}\right)$ e, no estádio $R_{7.8}$. Após o florescimento, ocorreu redução na massa seca de folhas em 
conseqüência da senescência, perda das folhas mais baixas e da, translocação de assimilados para os aquênios.

Andrade (1995), estudando o crescimento de milho, soja e girassol, observou que no início, o girassol apresentou taxa de acumulação de massa de matéria seca semelhante ao milho, e o ultrapassou, na interceptação da radiação fotossinteticamente ativa, devido à expansão de folhas e pelo seu arranjo no topo. Ainda em comparação com o milho, o girassol apresentou maior capacidade de compensar o baixo número de grãos por área com gräos mais pesados. Obteve também valores de taxa de crescimento da cultura, dos 40 aos 80 dias após a emergência, entre $31 \pm 1,4 \mathrm{~g} \mathrm{~m}^{-2}$ e índice de colheita próximo a 0,29 .

Bange et al. (1997), avaliando três genótipos de girassol (8640, Suncross 41 , 8793) em duas épocas de semeadura (13/09 e 05/03), obtiveram rendimento médio de aquênios por época, de 6,0 e 2,2 $\mathrm{t} \mathrm{ha}^{-1}$, respectivamente. Segundo os autores, o alto rendimento observado na primeira época, foi resultado da alta assimilação de biomassa associada à alta radiação, alta interceptação de luz pelo índice de área foliar elevado, è à eficiência no uso da radiação. As diferenças na radiação causaram redução na partição de assimilados para os grãos, associada com a redução no período de enchimento de aquênios. Considerando todos os genótipos, o índice de área foliar na antese foi superior na primeira época, atingindo seu valor máximo aos 60 dias após a semeadura (DAS). Os menores valores de IAF encontrados na segunda época estavam associados às baixas temperaturas e à radiação incidente antes da colheita, atingido seu valor máximo aos 50 DAS.

A análise de crescimento de dois hibridos de girassol GR 18 e GR 10, de ciclos precoce e tardio, respectivamente, em resposta a niveis de adubação e épocas de semeadura (26/08 e 28/09), foi objeto de estudo de Barni et al. (1995b). Os autores observaram que a taxa de crescimento da cultura foi 
superior no subperíodo de rápido crescimento ativo da cultura, decrescendo no estádio de diferenciação do primórdio floral $\left(R_{1}\right)$. A taxa de crescimento relativo e a área foliar por unidade de massa de matéria seca aérea (RAF), foram altas no início do ciclo e decresceram com o avanço do ciclo da cultura até a maturação fisiológica.

Sobarad et al. (1996) estudando os efeitos de datas de semeadura

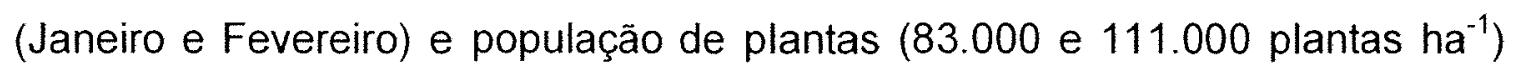
sobre o rendimento e parâmetros fisiológicos de duas variedades de girassol (Morden e BSH-1), verificaram na menor população, aumentos de rendimentos de aquênios atribuídos aos valores significativamente superiores de área foliar por planta, produção de massa de matéria seca aos 60 DAS e na colheita, índice de colheita e \% de enchimento de aquênios.

Para Villalobos et al. (1996), em faixas de densidades de 0,5 a 10 plantas $\mathrm{m}^{-2}$, o indice de colheita de hibridos de ciclo curto aumentou continuamente, enquanto que para os híbridos de ciclo longo, isto ocorreu entre 5 e 10 plantas $\mathrm{m}^{-2}$. Essa diferença foi atribuida à plasticidade limitada no número e massa de aquênios apresentada pelos híbridos de ciclo curto. 


\section{MATERIAL E MÉTODOS}

\subsection{Local e período de experimentação}

A pesquisa foi realizada em área experimental da Fazenda Areão pertencente a Escola Superior de Agricultura "Luiz de Queiroz", no município de Piracicaba - SP, localizada a $22^{\circ} 41^{\prime}$ de latitude Sul, $47^{\circ} 38^{\prime}$ de longitude Oeste e $573 \mathrm{~m}$ de altitude, durante o ano agrícola 1998/1999.

\subsection{Características do solo}

O experimento foi conduzido em um solo Podzólico Vermelho Escuro, cujas características de fertilidade são apresentados na Tabela 1 , fundamentadas em amostragem do solo da área experimental.

Tabela 1. Características de fertilidade do solo da área experimental. Piracicaba, SP. 1999

\begin{tabular}{|c|c|c|c|c|c|c|c|c|c|c|c|}
\hline \multirow{2}{*}{$\begin{array}{l}\text { Prof. } \\
(\mathrm{cm})\end{array}$} & \multirow{2}{*}{$\begin{array}{c}\mathrm{pH} \\
\mathrm{CaCl}_{2}\end{array}$} & M. O. & $P$ & K & $\mathrm{Ca}$ & $\mathrm{Mg}$ & Al & $\mathrm{H}+\mathrm{Al}$ & SB & $\mathrm{T}$ & $V \quad M$ \\
\hline & & $\left(\mathrm{g} \mathrm{dm}^{-3}\right)$ & $\left.g \mathrm{gm}^{-3}\right)$ & \multicolumn{7}{|c|}{$\left(\mathrm{mmol}_{\mathrm{c}} \mathrm{dm}^{-3}\right)$} & $(\%)$ \\
\hline $00-20$ & 5,1 & 29 & 8 & 2,7 & 33 & 24 & 0 & 38 & 59,7 & 97,7 & 610 \\
\hline $20-40$ & 4,1 & 24 & 4 & 0,9 & 14 & 10 & 8 & 98 & 24,9 & 123 & $20 \quad 24$ \\
\hline \multirow{2}{*}{\multicolumn{2}{|c|}{$\begin{array}{l}\text { Prof. } \\
(\mathrm{cm})\end{array}$}} & \multicolumn{2}{|l|}{ B } & $\mathrm{Cu}$ & & \multicolumn{2}{|c|}{$\mathrm{Fe}$} & \multicolumn{3}{|c|}{$\mathrm{Mn}$} & $\mathrm{Zn}$ \\
\hline & & \multicolumn{10}{|c|}{$\left(m g d^{-3}\right)$} \\
\hline \multicolumn{2}{|c|}{$00-20$} & \multicolumn{2}{|c|}{0,23} & \multicolumn{2}{|l|}{1,1} & \multicolumn{2}{|c|}{1,72} & \multicolumn{2}{|c|}{7,5} & \multicolumn{2}{|r|}{0,6} \\
\hline \multicolumn{2}{|c|}{$20-40$} & \multicolumn{2}{|c|}{0,18} & \multicolumn{2}{|l|}{1,0} & \multicolumn{2}{|c|}{18,0} & \multicolumn{3}{|c|}{4,7} & 0,3 \\
\hline
\end{tabular}


Este ano experimental, correspondeu ao segundo ano após a incorporação de $4 \mathrm{t}$ ha ${ }^{-1}$ de calcário dolomítico e aplicação de $1 \mathrm{t} \mathrm{ha}{ }^{-1}$ de gesso. Provavelmente, devido à ineficiente incorporação dos insumos, a correção da fertilidade do solo na profundidade de 20 a $40 \mathrm{~cm}$ ficou aquém da desejada, justificando $24 \%$ de saturação de alumínio. De acordo com Raij et al. (1996), o teor de fósforo apresentou niveis baixos e o potássio manteve-se em nivel médio de fertilidade.

Com relação aos teores de micronutrientes, cobre, ferro e manganês apresentaram-se em niveis elevados, enquanto zinco encontrava-se com nível médio de fertilidade. Especificamente o boro, com $0,23 \mathrm{mg} \mathrm{dm}^{-3}$ nos primeiros $20 \mathrm{~cm}$ de solo, apresentou-se inferior ao limite de $0,40 \mathrm{mg} \mathrm{dm}^{-3}$ considerado como teor mínimo para boa produtividade de girassol segundo Embrapa (1983).

\subsection{Cultivares}

Foram utilizados os cultivares Cargill 11 e Morgan 734, recomendados pela Embrapa (1999) para a região produtora do Estado de São Paulo, cujas principais características são apresentadas na Tabela 2. 
Tabela 2. Principais características de alguns cultivares de girassol

\begin{tabular}{ccc}
\hline Características & Cargill 11 & Morgan 734 \\
\hline Tipo de híbrido & Simples & Simples \\
Ciclo (classificação) & Semi precoce & Precoce \\
Ciclo (dias) & 125 & $120-125$ \\
Floração (dias) & 68 & 62 \\
Maturação Fisiológica (dias) & 115 & 98 \\
Altura de planta (m) & 1,80 & 1,90 \\
Cor dos aquênios & marrom estriado & estriado claro \\
Massa de 1000 aquênios (g) & $30-50$ & $40-60$ \\
Teor de óleo (\%) & $41-48$ & $39-43$ \\
\hline
\end{tabular}

Fonte: Cargill s.d; Dow AgroSciences s.d.; EMBRAPACNPSo, 2000 (comunicação pessoal).

\subsection{Densidade de plantas}

Os cultivares Cargill 11 e Morgan 734 foram semeados com quantidades de sementes suficientes para obtenção das populações desejadas, mantendose constante o espaçamento entrelinhas, conforme a Tabela 3 .

Tabela 3. Densidade de plantas na linha e respectivas populações por hectare

\begin{tabular}{cccc}
\hline $\begin{array}{c}\text { Espaçamento } \\
\text { entre linhas }(\mathrm{m})\end{array}$ & $\begin{array}{c}\text { Densidades } \\
\left(\text { plantas } \mathrm{m}^{-1}\right)\end{array}$ & $\begin{array}{c}\text { Densidades } \\
\left(\text { plantas }^{-2}\right)\end{array}$ & $\begin{array}{c}\text { Populações } \\
\left.\text { (plantas ha }^{-1}\right)\end{array}$ \\
\hline 0,75 & 2 & 2,6 & 26.667 \\
0,75 & 3 & 4,0 & 40.000 \\
0,75 & 4 & 5,3 & 53.333 \\
0,75 & 5 & 6,7 & 66.667 \\
0,75 & 6 & 8,0 & 80.000 \\
\hline
\end{tabular}




\subsection{Instalação e Condução do experimento}

A semeadura foi realizada em 26 de março de 1999 com semeadoraadubadora de parcelas. As sementes utilizadas, foram previamente tratadas com a mistura fungicida "carboxin + thiram" na dose do produto comercial equivalente a $300 \mathrm{ml}$ por $100 \mathrm{~kg}^{-1}$ de sementes.

Como adubação de semeadura, adotou-se o critério proposto por Quaggio e Ungaro (1996), que recomendam aplicar $10-50-30 \mathrm{~kg} \mathrm{ha}^{-1}$ de $\mathrm{N}$, $\mathrm{P}_{2} \mathrm{O}_{5}$ e $\mathrm{K}_{2} \mathrm{O}$, respectivamente. Dessa forma, aplicou-se $400 \mathrm{~kg} \mathrm{ha}^{-1}$ da fórmula 0-15-10, contendo também $0,7 \%$ de $\mathrm{Zn}, 0,5 \%$ de $\mathrm{Mn}, 0,1 \%$ de Cu e $0,13 \%$ de $\mathrm{B}$. Assim, a adubação por hectare correspondeu à aplicação de $60 \mathrm{~kg}$ de $\mathrm{P}_{2} \mathrm{O}_{5}, 40$ $\mathrm{kg}$ de $\mathrm{K}_{2} \mathrm{O}, 2,8 \mathrm{~kg}$ de zinco, $2 \mathrm{~kg}$ de manganês, $0,4 \mathrm{~kg}$ de cobre e $0,5 \mathrm{~kg} \mathrm{ha}^{-1}$ de boro.

Com relação ao nitrogênio, decidiu-se apenas pela aplicação em cobertura, aos 30 dias após a emergência, juntamente com o boro. Foram utilizados como fontes desses nutrientes, sulfato de amônio e ulexita, que forneceram respectivamente, $45 \mathrm{~kg}$ de nitrogênio e $1,5 \mathrm{~kg}$ de boro por hectare.

Visando o controle químico das plantas daninhas até o fechamento do solo pelas plantas de girassol, foram aplicados três dias após a semeadura, os herbicidas trifluralina e glifosate, na dosagem do produto comercial de $4 \mathrm{~L} \mathrm{ha}^{-1}$ cada um.

Para o controle da lagarta preta do girassol (Chlosyne lacinia saundersii), aplicou-se uma vez o inseticida piretróide lambdacyhalothrin, na dose do produto comercial de $0,6 \mathrm{~L} \mathrm{ha}^{-1}$, dirigindo-se o jato da calda inseticida sobre as colônias dessa praga. Para o controle preventivo da Mancha de Alternária, nos estádios $V_{8}$ e $R_{4}$, aplicou-se em cada ocasião $0,250 \mathrm{~kg} \mathrm{ha}^{-1}$ do fungicida Benomyl ( $0,5 \mathrm{~kg} \mathrm{ha}^{-1}$ de Benlate).

Para garantir a emergência e o desenvolvimento das plantas até o final do ciclo, foi instalado o sistema de irrigação por aspersão, aplicando-se uma lâmina de 0,015 $\mathrm{m}$ de altura, seguindo a freqüência de uma irrigação a cada duas semanas. 
Após a colheita, os capítulos foram colocados para secar ao ar livre em terreiro, para perder umidade e permitir a trilha mecânica.

\subsection{Características avaliadas}

\subsubsection{Desenvolvimento fenológico}

Após a definição dos estandes, acompanhou-se o desenvolvimento fenológico com base na observação de 10 plantas localizadas nas linhas úteis de cada parcela, segundo a Escala Fenológica proposta por Schneiter e Miller (1981) apresentada nas Tabelas 4 e 5.

Tabela 4. Descrição dos estádios vegetativos do girassol

\begin{tabular}{|c|c|c|}
\hline Símbolo & Denominação & Descrição \\
\hline$V_{E}$ & Emergência & $\begin{array}{l}\text { Desde a emergência epígea até a primeira folha } \\
\text { com no máximo } 4 \mathrm{~cm} \text {, acima dos cotilédones }\end{array}$ \\
\hline$V_{1}$ & Primeira folha & $\begin{array}{l}\text { Primeiro nó vegetativo com folha apresentando } \\
\text { pelo menos } 4 \mathrm{~cm} \text { de comprimento }\end{array}$ \\
\hline$V_{2}$ & Segunda folha & $\begin{array}{l}\text { Segundo nó vegetativo com folha apresentando } \\
\text { pelo menos } 4 \mathrm{~cm} \text { de comprimento }\end{array}$ \\
\hline$V_{3}$ & Terceira folha & $\begin{array}{l}\text { Terceiro nó vegetativo com folha apresentando pelo } \\
\text { menos } 4 \mathrm{~cm} \text { de comprimento }\end{array}$ \\
\hline$V_{n}$ & Enésima folha & $\begin{array}{l}\text { "Enésimo" nó vegetativo com folha apresentando } \\
\text { pelo menos } 4 \mathrm{~cm} \text { de comprimento }\end{array}$ \\
\hline
\end{tabular}

Fonte: Schneiter e Miller (1981). 
Tabela 5. Descrição dos estádios reprodutivos do girassol

\begin{tabular}{|c|c|c|}
\hline Símbolo & Denominação & Descrição \\
\hline $\mathrm{R}_{1}$ & Pequeno botão floral & $\begin{array}{l}\text { Vista por cima, a extremidade apical da haste } \\
\text { apresenta-se com brácteas envolvendo o botão } \\
\text { floral, lembrando uma pequena "estrela". }\end{array}$ \\
\hline $\mathrm{R}_{2}$ & $\begin{array}{l}1^{\circ} \text { Alongamento do } \\
\text { botão floral }\end{array}$ & $\begin{array}{l}\text { O botão floral distancia-se de } 0,5 \text { a } 2,0 \mathrm{~cm} \text { da } \\
\text { última folha }{ }^{1}\end{array}$ \\
\hline $\mathrm{R}_{3}$ & $\begin{array}{l}2^{\circ} \text { Alongamento do } \\
\text { botão floral }\end{array}$ & $\begin{array}{l}\text { O botão floral distancia-se acima de } 2,0 \mathrm{~cm} \text { da } \\
\text { última folha. }\end{array}$ \\
\hline $\mathrm{R}_{4}$ & $\begin{array}{l}1^{\text {a }} \text { Fase do } \\
\text { florescimento }\end{array}$ & $\begin{array}{l}\text { Capítulo com brácteas abertas e flores } \\
\text { liguladas fechadas ou parcialmente abertas. }\end{array}$ \\
\hline $\mathrm{R}_{5}$ & $\begin{array}{l}2^{\text {a }} \text { Fase do } \\
\text { florescimento }\end{array}$ & $\begin{array}{l}\text { Refere-se ao florescimento das flores } \\
\text { tubulares, podendo ser subdividida conforme a } \\
\text { porcentagem do disco floral com flores abertas, } \\
\text { tomando-se como referência a floração da } \\
\text { periferia para o centro do capitulo. }\end{array}$ \\
\hline $\mathrm{R}_{5.1}$ & Florescimento inicial & $\begin{array}{l}10 \% \text { do disco floral com flores tubulares } \\
\text { abertas. }\end{array}$ \\
\hline $\mathrm{R}_{5.5}$ & $\begin{array}{l}\text { Florescimento } \\
\text { mediano }\end{array}$ & $\begin{array}{l}50 \% \text { do disco floral com flores tubulares } \\
\text { abertas. }\end{array}$ \\
\hline $\mathrm{R}_{5.9}$ & $\begin{array}{l}90 \% \text { do } \\
\text { Florescimento }\end{array}$ & $\begin{array}{l}90 \% \text { do disco floral com flores tubulares } \\
\text { abertas. }\end{array}$ \\
\hline $\mathrm{R}_{6}$ & $\begin{array}{l}\text { Florescimento } \\
\text { completo }\end{array}$ & $\begin{array}{l}100 \% \text { de flores tubulares abertas e flores } \\
\text { liguladas murchas. }\end{array}$ \\
\hline $\mathrm{R}_{7}$ & $\begin{array}{l}1^{\text {a }} \text { Fase de } \\
\text { desenvolvimento } \\
\text { dos aquênios }\end{array}$ & $\begin{array}{l}\text { O dorso do capítulo apresenta coloração } \\
\text { variável e progressivo do verde para o } \\
\text { amarelo-claro, porém, com brácteas verdes. }\end{array}$ \\
\hline $\mathrm{R}_{8}$ & $\begin{array}{l}2^{\text {a }} \text { Fase de } \\
\text { desenvolvimento } \\
\text { dos aquênios }\end{array}$ & $\begin{array}{l}\text { O dorso do capítulo apresenta-se amarelo- } \\
\text { escuro, porém, com brácteas verdes. }\end{array}$ \\
\hline $\mathrm{R}_{9}$ & $\begin{array}{l}\text { Maturação } \\
\text { Fisiológica }\end{array}$ & $\begin{array}{l}\text { O dorso do capitulo apresenta-se com cor } \\
\text { castanha a marrom e as brácteas estão entre a } \\
\text { cor amarela e castanha. }\end{array}$ \\
\hline
\end{tabular}

Considera-se como última folha aquela que está unida ao haste.

Fonte: Schneiter e Miller (1981). 


\subsubsection{Análise de Crescimento}

Para efetuar a análise de crescimento, foram utilizados dados de massa seca total e índice de área foliar, para os quais, foram obtidos ajustes equacionais para descrever sua variação temporal através do programa Table Curve (Jandel Scientific). Posteriormente, os índices fisiológicos, taxa de crescimento da cultura, taxa de crescimento relativo, taxa de assimilação líquida e razão de área foliar foram determinados através das funções ajustadas para massa seca total e índice de área foliar, de acordo com vários autores (Blackman, 1919; Reis e Muller, 1979; Hunt, 1982; Magalhães, 1985; Pereira e Machado, 1987; Benincasa, 1988 e Peixoto, 1999).

\subsubsection{Massa seca (MS)}

A massa seca total, definida como sendo a fitomassa de toda a planta, foi determinada em intervalos regulares de 14 dias, através da coleta de 10 plantas de girassol por amostragem. As coletas iniciaram-se aos 26 dias após a emergência com sete épocas de amostragem: $26,40,54,68,82,96$ e 110 dias após a emergência das plantas, finalizando-se no estádio $R_{8}$. Em cada coleta, as plantas foram separadas em partes (folhas, hastes, capítulos e aquênios). As raizes, particularmente, foram retiradas em blocos de terra, e posteriormente lavadas em peneiras. As partes da planta foram colocadas a secar e posteriormente, levadas à estufa de ventilação forçada à temperatura de $75^{\circ} \mathrm{C}$, até atingirem massa seca constante.

A variação temporal da massa seca total foi descrita pela equação:

$$
M S T=\frac{a}{\left(1+\exp \left(-\frac{(t-b)}{c}\right)\right)}
$$

Em que: $a, b, \quad$ e $c$ são coeficientes empíricos determinados estatisticamente e $t$ é o valor em dias após a emergência. 


\subsubsection{2 İndice de área foliar (IAF)}

$O$ índice de área foliar foi determinado em cada coleta, utilizando-se o analisador de dossel Li-cor®, modelo LAI-2000.

A variação temporal do índice de área foliar foi descrita pela equação:

$$
I A F=\frac{4 a \exp \left(-\frac{(t-b)}{c}\right)}{\left(1+\exp \left(-\frac{(t-b)}{c}\right)\right)^{2}}
$$

Em que: $a, b, \quad$ e $c$ são coeficientes empíricos determinados estatisticamente e $t$ é o valor em dias após a emergência.

\subsubsection{Taxa de crescimento da cultura (TCC)}

A TCC $\left(\mathrm{g} \mathrm{m}^{-2} \mathrm{dia}^{-1}\right)$ avalia a produtividade primária líquida. É o somatório das taxas de crescimento dos diversos componentes das plantas (Reis e Muller, 1979; Pereira e Machado, 1987).

$$
T C C=\frac{d M S}{d t}
$$

\subsubsection{Taxa de crescimento relativo (TCR)}

A TCR $\left(\mathrm{g} \mathrm{g}^{-1} \mathrm{dia}^{-1}\right)$ expressa o incremento na massa seca, por unidade de massa inicial, em um intervalo de tempo (Reis e Muller, 1979). Para Pereira e Machado (1987), usa-se:

$$
T C R=\frac{T C C}{M S}
$$




\subsubsection{Taxa de assimilação líquida (TAL)}

A TAL ( $\mathrm{g} \mathrm{dia}^{-1} \mathrm{~m}^{-2}$ ) representa a taxa de incremento de massa seca por unidade de área foliar existente na planta, assumindo que tanto IAF como MS, aumentam exponencialmente (Briggs et al., 1920; Pereira e Machado, 1987):

$$
T A L=\frac{T C C}{I A F}
$$

\subsubsection{Razão de área foliar (RAF)}

A RAF $\left(\mathrm{m}^{2} \mathrm{~g}^{-1}\right)$ representa a relação entre a área foliar e a massa seca total da planta. É também chamado quociente de área foliar (Briggs et al., 1920; Pereira e Machado, 1987).

$$
R A F=\frac{A F}{M S}
$$

\subsubsection{7 Índice de colheita (IC)}

O índice de colheita é definido pela razão entre massa seca do órgão economicamente importante e a massa seca total da planta, representa a eficiência de conversão de produtos sintetizados em material de importância econômica, sendo determinado tanto pelo genótipo como pelo ambiente.

No caso do girassol, refere-se a fitomassa seca de aquênios (FSA) sobre a fitomassa seca total colhida (FST):

$$
I C=\frac{F S A}{F S T}
$$

\subsubsection{Características agronômicas}

\subsubsection{Número de Folhas (NF)}

Durante a fase de alongamento do botão floral $\left(R_{3}\right.$ e $\left.R_{4}\right)$, observando-se 10 plantas localizadas nas linhas úteis de cada parcela, foi determinado o 
número de folhas, a partir da superfície do solo até a base do botão floral, desconsiderando as cicatrizes dos cotilédones.

\subsubsection{Altura final de planta (AFP)}

A altura média foi determinada com base na observação de 10 plantas amostrais por parcela, considerando-se como altura final de planta, a distância compreendida entre a superfície do solo e a região central de cada capítulo, conforme descrito por Castiglioni et al. (1994).

\subsubsection{Diâmetro basal da haste (DH)}

Em 10 plantas por parcela e por meio de paquímetro, foi feita leitura do diâmetro basal da haste do girassol, em ponto localizado a $10 \mathrm{~cm}$ acima do nível do solo.

\subsubsection{Diâmetro de capítulo (DC)}

Com auxilio de régua graduada mediu-se o diâmetro de capítulo ou receptáculo floral, considerando-se como diâmetro, a linha imaginária que une duas extremidades do receptáculo floral, passando pelo centro do capitulo. Também foram utilizadas 10 plantas de girassol, cujos receptáculos florais se apresentem uniformemente formados.

\subsubsection{Número de aquênios por capítulo (NA)}

Após a determinação do diâmetro dos capitulos, estes foram manualmente debulhados e os aquênios obtidos foram beneficiados. Em seguida, os aquênios provenientes de cada capítulo foram contados para determinação do número médio de frutos formados por receptáculo.

\subsubsection{Massa de mil aquênios (M1000)}

Foram separadas, manualmente, oito sub-amostras de 100 aquênios para cada parcela, as quais foram pesadas em balança com sensibilidade de 
centésimos de gramas. Os valores observados foram corrigidos para $13 \%$ de umidade, sendo tais procedimentos efetuados segundo prescrições estabelecidas pelas Regras de Análise de Sementes (Brasil - Ministério da Agricultura, 1992).

\subsubsection{Rendimento de aquênios (REND)}

O rendimento de aquênios ou produtividade agrícola, foi avaliada a partir das duas linhas centrais de cada parcela, transformando-se, posteriormente, os dados de $\mathrm{kg}_{\text {parcela }}{ }^{-1}$ para $\mathrm{kg} \mathrm{ha}^{-1}$, corrigindo-se a produção de todas as parcelas uniformemente à $13 \%$ de umidade.

\subsection{Delineamento experimental}

O delineamento experimental utilizado no ensaio foi de blocos casualizados, em esquema fatorial $2 \times 5$, sendo dois cultivares (Cargill $11 \mathrm{e}$ Morgan 734) e cinco densidades de plantas $\left(2,3,4,5\right.$ e 6 plantas $\left.\mathrm{m}^{-1}\right)$, conduzidos em três repetições. A parcela experimental foi constituída por 18 linhas de $10 \mathrm{~m}$ de comprimento.

Todos os dados coletados foram analisados estatisticamente, por meio da análise da variância. Os efeitos estatisticamente significativos dos cultivares pelo teste $F$, foram analisados pelo teste de Tukey, visando-se a comparação de médias. Quando o objetivo foi estudar as diferentes densidades, utilizou-se a análise de regressão polinomial. A utilização de equações de regressão para representar o comportamento do crescimento ao longo do ciclo, permite avaliar de forma mais precisa, variações no padrão de crescimento de plantas em relação a uma característica, como massa seca ou índice de área foliar, em função de tratamentos impostos ou de variabilidade genética entre os cultivares estudados. Os erros que não apresentaram distribuição normal ou variâncias heterogêneas, foram transformados segundo $\sqrt{x+0,5}$.

O esquema das análises das variâncias para os valores de rendimento e os utilizados para a análise de crescimento dentro dos estádios fenológicos 
estudados são apresentados na Tabela 6, utilizando-se o modelo matemático a seguir:

$$
y_{i j k}=\mu+\alpha_{i}+\beta_{j}+\gamma_{i j}+\delta_{k}+e_{i j k}
$$

Em que,

$i=1,2$

$$
j=1,2,3,4,5
$$$$
k=1,2,3
$$

$\mu$ : constante do modelo;

$\alpha_{i}$ : efeito do $\mathrm{i}$ - ésimo cultivar;

$\beta_{\mathrm{j}}$ : efeito da $\mathrm{j}$ - ésima densidade;

$\gamma_{\mathrm{ij}}$ : efeito da interação cultivar com densidade;

$\delta_{k}$ : efeito do k - ésimo bloco;

$e_{\mathrm{ijk}}$ : erro experimental não observável, tal que $\mathrm{e}_{\mathrm{ijk}} \cap \mathrm{N}\left(0, \sigma^{2}\right)$.

Tabela 6. Esquema da análise da variância individual

\begin{tabular}{cc}
\hline Fontes da variação & Graus de liberdade \\
\hline Bloco & 2 \\
Cultivar (C) & 1 \\
Densidade (D) & 4 \\
Interação C * D & 4 \\
Resíduo & 18 \\
\hline Total & 29 \\
\hline
\end{tabular}




\section{RESULTADOS E DISCUSSÃO}

\subsection{Desenvolvimento fenológico e clima}

Como introdução à discussão dos resultados analisados estatisticamente, apresentam-se as condições climáticas durante o experimento (Tabela 7) e a duração em dias de alguns períodos fenológicos estudados do girassol (Tabela 8).

Os valores de radiação solar revelam que, para o época de desenvolvimento considerada como safrinha tardia, isto é, semeadura ocorrida na segunda quinzena de março, houve boa disponibilidade de radiação luminosa para a atividade fotossintética das plantas. Também foi observado boa disponibilidade de temperatura ao longo do período experimental, embora tenham ocorrido temperaturas minimas abaixo de 13 e $14^{\circ} \mathrm{C}$ durante a antese, prejudiciais a fecundação dos floretes e produção de aquênios.

Por outro lado, o índice pluviométrico de $236,1 \mathrm{~mm}$ foi insuficiente para atender a demanda hídrica da cultura, amenizado por meio da irrigação, aplicandose aproximadamente $200 \mathrm{~mm}$ de água distribuídos logo após a semeadura, início da antese, florescimento e enchimento dos aquênios. O total de $436,1 \mathrm{~mm}$ atendeu as necessidades hídricas da cultura, possibilitando obter produtividades entre 1.109 a $1.840 \mathrm{~kg}$ de aquênios por hectare. 
Tabela 7. Valores totais de radiação solar $(R S)$, precipitação $(P)$, precipitação acumulada $(\mathrm{Pa})$ e número de dias com chuva $(\mathrm{DC})$ e valores médios para temperaturas mínima (Tmín.), máxima (Tmáx.) e média (Tméd.), correspondentes a diferentes períodos fenológicos do girassol. Piracicaba, SP. 1999

\begin{tabular}{|c|c|c|c|c|c|c|c|c|}
\hline \multirow{2}{*}{$\begin{array}{c}\text { Período } \\
\text { Fenológico }^{1}\end{array}$} & \multirow{2}{*}{ Dias } & RS & Tmin. & Tmáx. & Tméd. & $P$ & $\mathrm{~Pa}$ & \multirow{2}{*}{ DC } \\
\hline & & $\left(\mathrm{cal} / \mathrm{cm}^{2}\right)$ & $\left({ }^{\circ} \mathrm{C}\right)$ & $\left({ }^{\circ} \mathrm{C}\right)$ & $\left({ }^{\circ} \mathrm{C}\right)$ & $(\mathrm{mm})$ & $(\mathrm{mm})$ & \\
\hline$S-V_{E}$ & 8 & 3.481 & 19,9 & 32,5 & 26,2 & 24,5 & - & 3 \\
\hline$V_{E}-R_{3}$ & 60 & 21.147 & 12,8 & 26,7 & 19,7 & 140,3 & 164,8 & 8 \\
\hline$R_{3}-R_{5.1}$ & 10 & 2.691 & 11,0 & 24,2 & 17,6 & 3,7 & 168,5 & 1 \\
\hline$R_{5.1}-R_{5.5}$ & 4 & 773 & 12,3 & 21,5 & 16,9 & 19,1 & 187,6 & 3 \\
\hline$R_{5.5}-R_{5.10}$ & 7 & 1.485 & 11,4 & 22,0 & 16,7 & 45,3 & 232,9 & 2 \\
\hline$R_{5.10}-R_{9}$ & 40 & 11.734 & 11,6 & 26,3 & 18,9 & 3,20 & 236,1 & 3 \\
\hline Média & & - & 13,1 & 25,5 & 19,3 & - & - & - \\
\hline Total & & 37.830 & - & - & - & 236,1 & - & 20 \\
\hline
\end{tabular}

Com base na escala fenológica proposta por Schneiter e Miller (1981) acompanhou-se o desenvolvimento das plantas de girassol (Tabela 8), observando-se que não houve estresse climático sobre a duração dos períodos fenológicos estudados, de maneira que os resultados que seguem são devidos aos tratamentos aplicados, salvo número de aquênios por capitulo, característica discutida mais adiante. 
Tabela 8. Duração em dias após a emergência de algumas fases fenológicos para cultivares de girassol, manejados sob diferentes densidades de plantas, em época de semeadura safrinha

\begin{tabular}{|c|c|c|c|c|c|c|}
\hline \multirow{3}{*}{ Cultivares } & \multirow{3}{*}{$\begin{array}{l}\text { Densidades } \\
\text { (plantas } \mathrm{m}^{-1} \text { ) }\end{array}$} & \multicolumn{5}{|c|}{ Fase fenológica } \\
\hline & & $\mathrm{FBF}^{1}$ & IA & MA & $A C$ & MC \\
\hline & & \multicolumn{5}{|c|}{ Dias após a emergência } \\
\hline \multirow{5}{*}{ C 11} & 2 & 60 & 70 & 77 & 84 & 123 \\
\hline & 3 & 60 & 70 & 77 & 84 & 123 \\
\hline & 4 & 60 & 70 & 77 & 84 & 123 \\
\hline & 5 & 60 & 70 & 77 & 84 & 123 \\
\hline & 6 & 60 & 70 & 77 & 84 & 123 \\
\hline \multirow{5}{*}{ M 734} & 2 & 60 & 67 & 70 & 81 & 123 \\
\hline & 3 & 60 & 67 & 70 & 84 & 123 \\
\hline & 4 & 60 & 70 & 77 & 84 & 123 \\
\hline & 5 & 60 & 70 & 77 & 84 & 116 \\
\hline & 6 & 60 & 70 & 77 & 84 & 116 \\
\hline
\end{tabular}

${ }^{1} \mathrm{FBF}$ : formação do botão floral; IA : inicio da antese; MA: metade da antese; $A C$ : antese completa e MC: maturação completa.

\subsection{Análise de Crescimento}

\subsubsection{Massa seca (MS)}

Os dados de massa seca total observados para os cultivares Cargill $11 \mathrm{e}$ Morgan 734, manejados sob cinco densidades de plantas na linha e semeados na época de semeadura safrinha, encontram-se nas Tabelas 9 a 15.

Nas fases fenonógicas $V_{12}, V_{21}$ e $R_{2}$ (Tabelas 9,10 e 11), as cultivares estudadas não diferiram significativamente quanto a massa seca acumulada. Nas demais fases fenológicas, $R_{4}-R_{5.1}, R_{5.6}-R_{5.8}, R_{6}$ e $R_{7}-R_{8}$ (Tabelas 12 a 15), a análise de variância revelou valores de $F$ significativos para o fator cultivar, com Morgan 734 apresentando maior massa seca quando comparado a Cargill 11, sem 
apresentar no entanto, significância para a interação entre cultivar e densidade (Apêndice 1).

Tabela 9. Massa Seca acumulada $\left(\mathrm{g} \mathrm{m}^{-2}\right)$ de cultivares de girassol no estádio $V_{12}$, manejados sob diferentes densidades de plantas, em época de semeadura safrinha

\begin{tabular}{|c|c|c|c|c|c|c|}
\hline \multirow{2}{*}{ Cultivares } & \multicolumn{5}{|c|}{ Densidades (plantas $\mathrm{m}^{-1}$ ) } & \multirow{2}{*}{ Médias } \\
\hline & 2 & 3 & 4 & 5 & 6 & \\
\hline C 11 & $24,35^{1}$ & 28,57 & 40,29 & 53,01 & 57,37 & $39,66 \mathrm{a}$ \\
\hline M 734 & 22,32 & 31,62 & 44,25 & 54,17 & 58,17 & $40,94 \mathrm{a}$ \\
\hline Média & 23,33 & 30,07 & 42,25 & 53,29 & 57,77 & \\
\hline D.M.S. ${ }^{2}$ & 0,37 & & C.V. (\%) & 7,49 & & \\
\hline
\end{tabular}

No estudo de densidades de plantio, foi observado através da análise de regressão polinomial valores de F significativos para massa seca acumulada em todos as fases fenológicas, sendo que o modelo genérico que mais se ajustou aos dados foi o modelo de regressão linear crescente, cujas equações são apresentadas no Anexo $A$. De acordo com essas equações, no estádio $V_{12}$, cada acréscimo de uma planta na densidade de plantio ocasiona aumento médio de $0,5373 \mathrm{~g} \mathrm{~m}^{-2}$ na massa seca do girassol (Figura 1), e para os estádios $V_{21}, R_{2}, R_{4^{-}}$ $R_{5.1}, R_{5.6}-R_{5.8}, R_{6}$ e $R_{7}-R_{8}$, esse aumento é de 1,1881 (Figura 2), 1,30 (Figura 3);

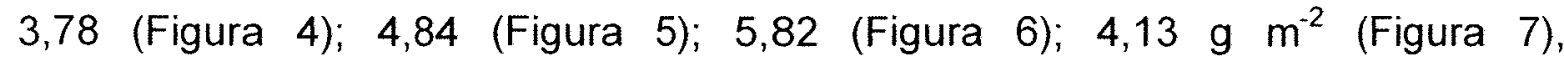
respectivamente. Em todos os ajustes, os valores do coeficiente de determinação foram maiores que 90 , com exceção do estádio $R_{2}$, que apresentou coeficiente de determinação menor $\left(R^{2}=0,8185\right)$, ainda assim, considerado como um bom ajuste.

Como os modelos ajustados são lineares e crescentes para todos os estádios fenológicos avaliados, não foi possível estabelecer valores máximos, dentro do intervalo de densidades de plantas avaliadas. Dessa forma, para a maior 
densidade de plantas estudada $\left(6\right.$ plantas $\left.\mathrm{m}^{-1}\right)$, foram obtidos os maiores valores de massa seca total.

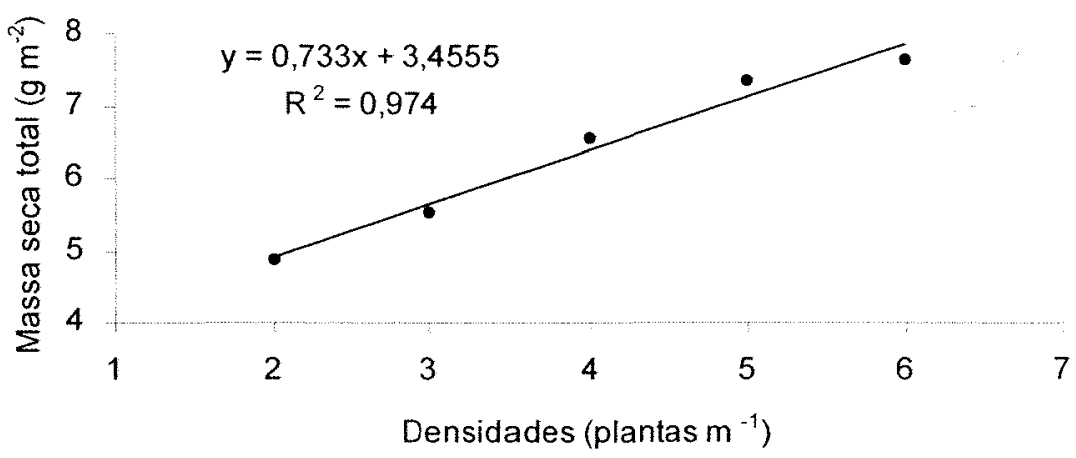

Figura 1 - Massa seca total $\left(\mathrm{g} \mathrm{m}^{-2}\right)$ dos cultivares de girassol $C 11$ e $M 734$, no estádio $V_{12}$, em função de densidades de plantas na linha, em época de semeadura safrinha.

Tabela 10. Massa seca acumulada $\left(\mathrm{g} \mathrm{m}^{-2}\right)$ de cultivares de girassol no estádio $V_{21}$, manejados sob diferentes densidades de plantas, em época de semeadura safrinha

\begin{tabular}{|c|c|c|c|c|c|c|}
\hline \multirow{2}{*}{ Cultivares } & \multicolumn{5}{|c|}{ Densidades (plantas $\mathrm{m}^{-1}$ ) } & \multirow{2}{*}{ Médias } \\
\hline & 2 & 3 & 4 & 5 & 6 & \\
\hline C 11 & $115,04^{1}$ & 114,12 & 213,78 & 223,96 & 207,48 & $171,09 \mathrm{a}$ \\
\hline M 734 & 137,93 & 164,26 & 174,68 & 232,71 & 244,08 & $188,55 \mathrm{a}$ \\
\hline Média & 126,22 & 138,05 & 193,74 & 228,32 & 225,41 & \\
\hline
\end{tabular}

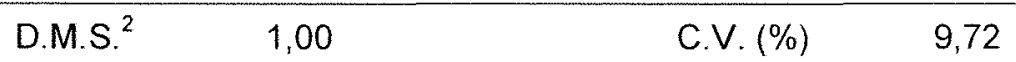

${ }^{1} \mathrm{Na}$ tabela encontram-se os valores originais, mas para fins de análise os dados foram transformados segundo $\sqrt{x+0,5}$.

${ }^{2}$ Diferença mínima significativa obtida dos dados transformados. 


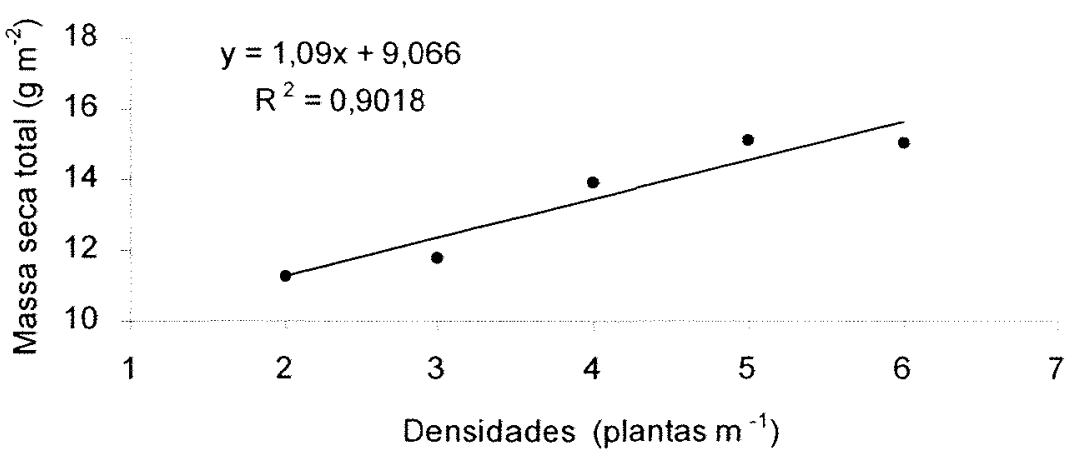

Figura 2 - Massa seca total $\left(\mathrm{g} \mathrm{m}^{-2}\right)$ dos cultivares de girassol C 11 e $M 734$, no estádio $V_{21}$, em função da densidades de plantas na linha em época de semeadura safrinha.

Tabela 11. Massa seca acumulada $\left(\mathrm{g} \mathrm{m}^{-2}\right)$ de cultivares de girassol no estádio $\mathrm{R}_{2}$, manejados sob diferentes densidades de plantas, em época de semeadura safrinha

\begin{tabular}{|c|c|c|c|c|c|c|}
\hline \multirow{2}{*}{ Cultivares } & \multicolumn{5}{|c|}{ Densidades (plantas $\mathrm{m}^{-1}$ ) } & \multirow{2}{*}{ Médias } \\
\hline & 2 & 3 & 4 & 5 & 6 & \\
\hline C 11 & $300,97^{1}$ & 306,52 & 333,16 & 536,94 & 452,16 & $380,61 \mathrm{a}$ \\
\hline M 734 & 272,99 & 442,39 & 452,06 & 445,08 & 447,37 & $408,57 \mathrm{a}$ \\
\hline Média & 286,81 & 371,35 & 390,35 & 489,94 & 449,76 & \\
\hline D.M.S. ${ }^{2}$ & 1,71 & & C.V. $(\%)$ & 11,19 & & \\
\hline
\end{tabular}

${ }^{1} \mathrm{Na}$ tabela encontram-se os valores originais, mas para fins de análise os dados foram transformados segundo $\sqrt{x+0,5}$.

${ }^{2}$ Diferença mínima significativa obtida dos dados transformados. 


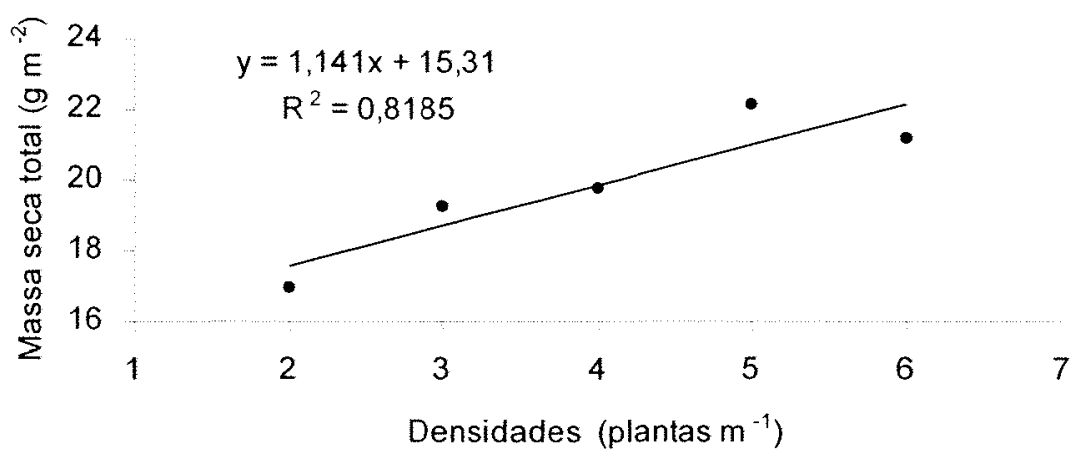

Figura 3 - Massa seca total $\left(\mathrm{g} \mathrm{m}^{-2}\right)$ dos cultivares de girassol C 11 e $M 734$, no estádio $R_{2}$, em função da densidades de plantas na linha em época de semeadura safrinha.

Tabela 12. Massa seca acumulada $\left(\mathrm{g} \mathrm{m}^{-2}\right)$ dos cultivares de girassol C 11 e $\mathrm{M} 734$, nos estádios $R_{4}$ e $R_{5.1}$ respectivamente, manejados sob diferentes densidades de plantas, em época de semeadura safrinha

\begin{tabular}{ccccccc}
\hline & \multicolumn{7}{c}{ Densidades (plantas m $^{-1}$ ) } & Médias \\
\cline { 2 - 6 } Cultivares & 2 & 3 & 4 & 5 & 6 & \\
\hline C 11 & $276,94^{1}$ & 325,83 & 394,33 & 434,96 & 544,13 & $389,93 \mathrm{~b}$ \\
M 734 & 288,76 & 402,79 & 523,33 & 653,45 & 654,51 & $493,61 \mathrm{a}$ \\
\hline Média & 282,82 & 363,29 & 456,55 & 538,67 & 598,04 & \\
\hline D.M.S. $^{2}$ & 0,95 & & C.V. $(\%)$ & 5,89 & &
\end{tabular}

' $\mathrm{Na}$ tabela encontram-se os valores originais, mas para fins de análise os dados foram transformados segundo $\sqrt{x+0,5}$

${ }^{2}$ Diferença minima significativa obtida dos dados transformados. 


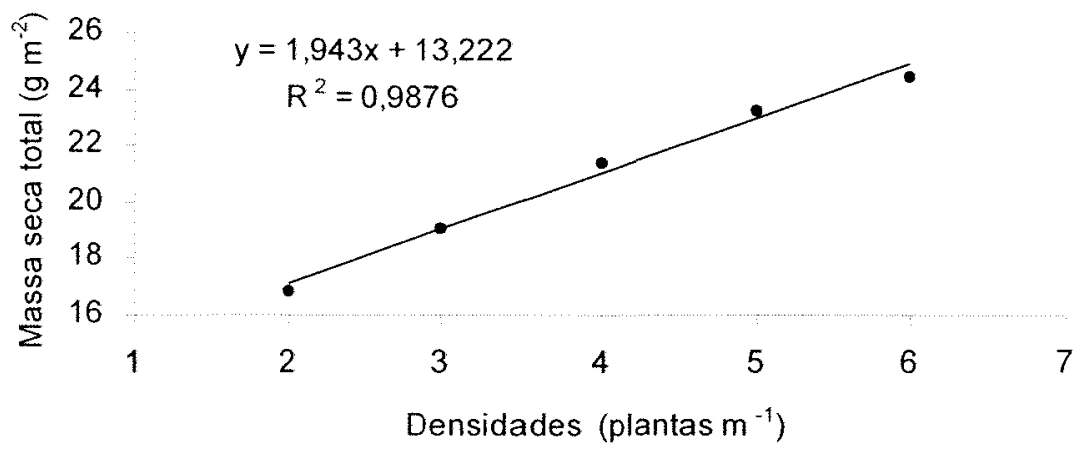

Figura 4 - Massa seca total $\left(\mathrm{g} \mathrm{m}^{-2}\right)$ dos cultivares de girassol C 11 e M 734, nos estádios $R_{4}$ e $R_{5.1}$ respectivamente, em função da densidades de plantas na linha em época de semeadura safrinha.

Tabela 13. Massa seca acumulada $\left(\mathrm{g} \mathrm{m}^{-2}\right)$ dos cultivares de girassol C 11 e M 734, nos estádios $R_{5.6}$ e $R_{5.8}$ respectivamente, manejados sob diferentes densidades de plantas, em época de semeadura safrinha

\begin{tabular}{|c|c|c|c|c|c|c|}
\hline \multirow{2}{*}{ Cultivares } & \multicolumn{5}{|c|}{ Densidades (plantas $\mathrm{m}^{-1}$ ) } & \multirow{2}{*}{ Médias } \\
\hline & 2 & 3 & 4 & 5 & 6 & \\
\hline C 11 & $370,76^{1}$ & 540,31 & 512,37 & 661,88 & 674,89 & $546,08 \mathrm{~b}$ \\
\hline M 734 & 409,35 & 507,35 & 572,52 & 708,47 & 1040,18 & $630,56 \mathrm{a}$ \\
\hline Média & 389,81 & 523,70 & 542,03 & 684,98 & 847,71 & \\
\hline $\begin{array}{l}\text { D.M.S. } \\
{ }^{1} \mathrm{Na} \text { tabela } \\
\text { transformados }\end{array}$ & $\begin{array}{l}1,63 \\
\text { ontram-se } \\
\text { egundo } \sqrt{ }\end{array}$ & $\frac{\text { valores }}{, 5}$ & $\begin{array}{l}\text { C.V. (\%) } \\
\text { ginais, ma }\end{array}$ & $\begin{array}{l}8,78 \\
\text { ra fins }\end{array}$ & álise & dos \\
\hline
\end{tabular}




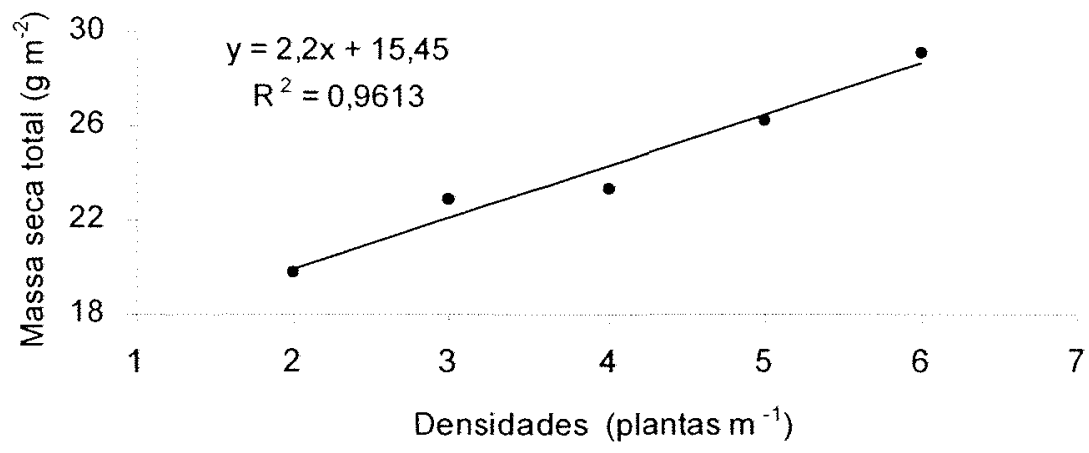

Figura 5 - Massa seca total $\left(\mathrm{g} \mathrm{m}^{-2}\right)$ dos cultivares de girassol $C 11$ e $M 734$, nos estádios $R_{5.6}$ e $R_{5.8}$ respectivamente, em função da densidades de plantas na linha em época de semeadura safrinha.

Tabela 14. Massa seca acumulada $\left(\mathrm{g} \mathrm{m}^{-2}\right)$ de cultivares de girassol no estádio $R_{6}$, manejados sob diferentes densidades de plantas, em época de semeadura safrinha

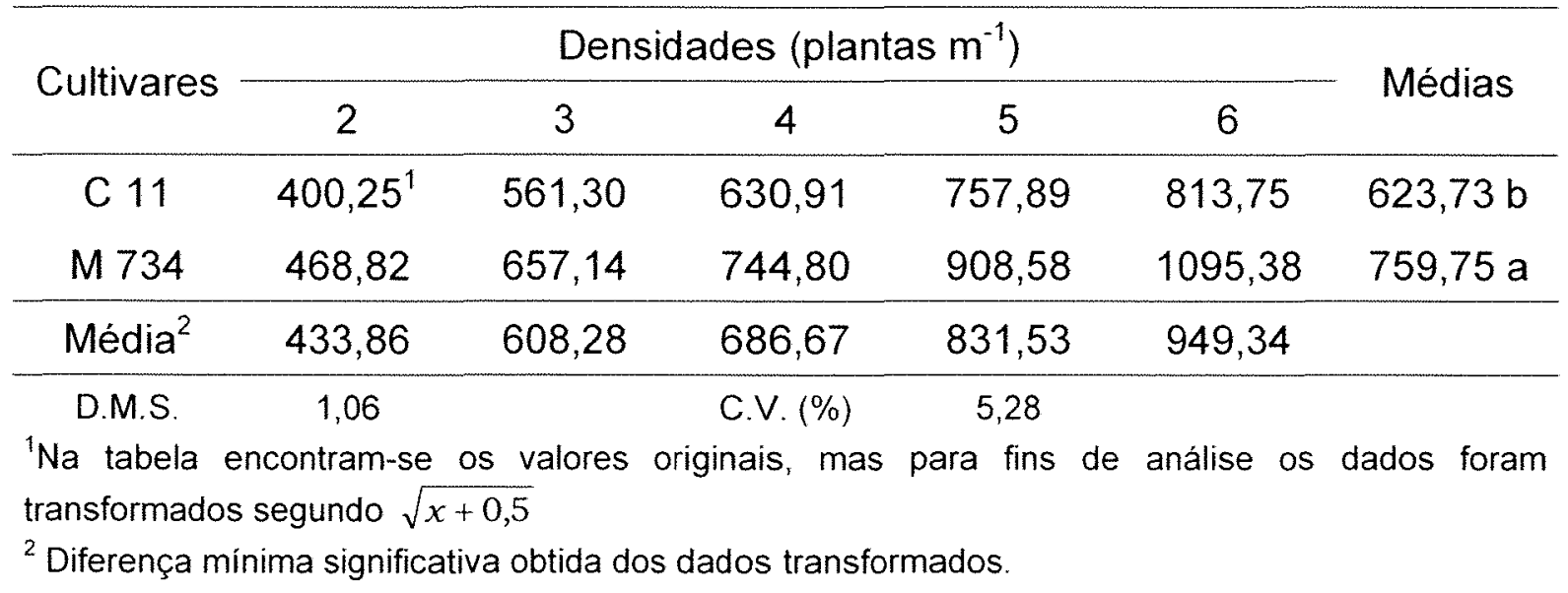




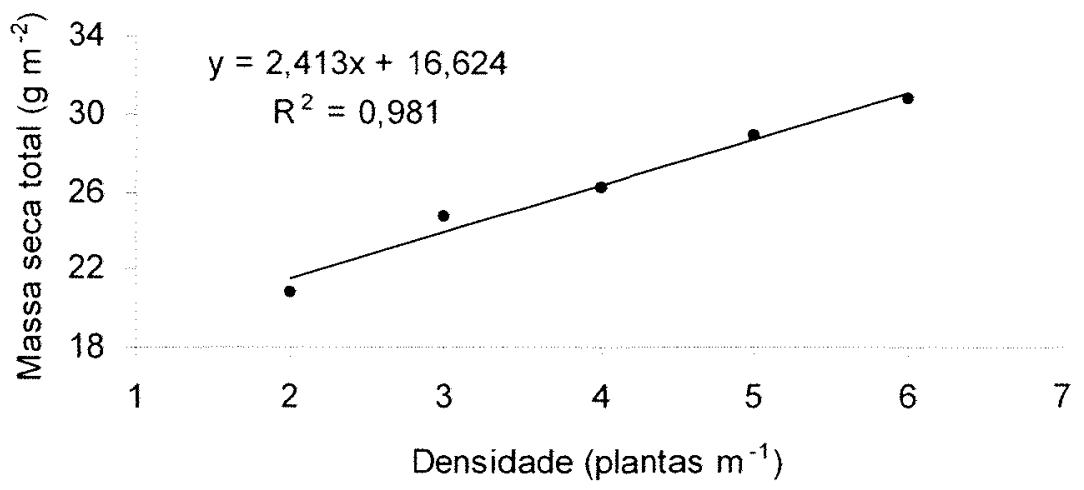

Figura 6 - Massa seca total $\left(\mathrm{g} \mathrm{m}^{-2}\right)$ de girassol para os cultivares $C 11$ e $M 734$, no estádio $R_{6}$, em função da densidades de plantas na linha em época de semeadura safrinha.

Tabela 15. Massa seca acumulada $\left(\mathrm{g} \mathrm{m}^{-2}\right)$ dos cultivares de girassol C 11 e $\mathrm{M} 734$, nos estádios $R_{7}$ e $R_{8}$ respectivamente, manejados sob diferentes densidades de plantas, em época de semeadura safrinha

\begin{tabular}{|c|c|c|c|c|c|c|}
\hline \multirow{2}{*}{ Cultivares } & \multicolumn{5}{|c|}{ Densidades (plantas $\mathrm{m}^{-1}$ ) } & \multirow{2}{*}{ Médias } \\
\hline & 2 & 3 & 4 & 5 & 6 & \\
\hline C 11 & $514,51^{1}$ & 647,31 & 807,84 & 854,03 & 970,71 & $749,98 \mathrm{~b}$ \\
\hline M 734 & 636,15 & 727,09 & 862,74 & 1076,38 & 1040,70 & 859,99 a \\
\hline Média & 573,72 & 686,62 & 835,07 & 961,99 & 1005,40 & \\
\hline $\begin{array}{l}\text { D.M.S. }{ }^{2} \\
\text { Na tabela }\end{array}$ & $\begin{array}{c}1,92 \\
\text { ontram-se }\end{array}$ & 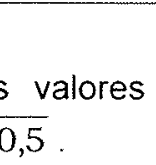 & $\begin{array}{l}\text { C.V. (\%) } \\
\text { inais, ma }\end{array}$ & $\begin{array}{c}8,85 \\
\text { para fins }\end{array}$ & & Jados \\
\hline
\end{tabular}




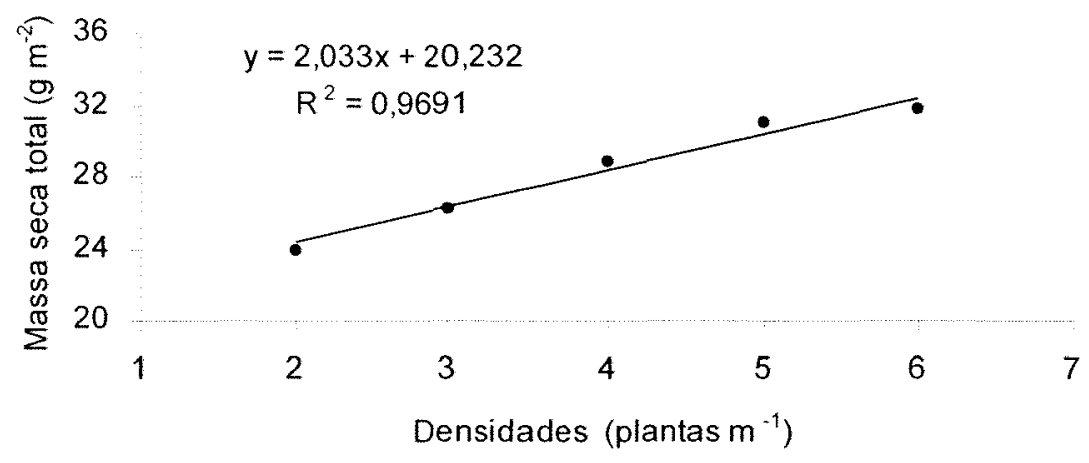

Figura 7 - Massa seca total $\left(\mathrm{g} \mathrm{m}^{-2}\right)$ dos cultivares de girassol C 11 e $M 734$, nos estádios $R_{7}$ e $R_{8}$ respectivamente, em função da densidades de plantas na linha em época de semeadura safrinha.

A massa seca produzida por unidade de planta, decresce com o aumento do número de plantas na linha, em função da competição intraespecífica pelos fatores de crescimento (Tabela 16). Resultados semelhantes foram encontrados por Cardinali et al. (1985), Sarmah et al. (1992) e Sobarad et al. (1996). No entanto, ao considerar a massa seca por unidade de área, verifica-se um efeito de compensação em densidades mais altas, pois o decréscimo na produção individual é parcialmente compensado pelo maior número de plantas. 
Tabela 16. Massa seca acumulada individualmente $\left(\mathrm{g} \mathrm{planta}^{-1}\right)$ e por unidade de área $\left(\mathrm{g} \mathrm{m}^{-2}\right)$ observados para cultivares de girassol, manejados sob diferentes densidades de plantas, em época de semeadura safrinha

\begin{tabular}{|c|c|c|c|}
\hline \multirow{2}{*}{ Cultivares } & \multirow{2}{*}{$\begin{array}{l}\text { Densidades } \\
\left(\text { plantas } \mathrm{m}^{-1} \text { ) }\right.\end{array}$} & \multicolumn{2}{|c|}{ Massa seca total } \\
\hline & & g planta ${ }^{-1}$ & $\mathrm{~g} \mathrm{~m}^{-2}$ \\
\hline \multirow{5}{*}{ C $11^{1}$} & 2 & 192,93 & 514,51 \\
\hline & 3 & 161,82 & 647,31 \\
\hline & 4 & 151,47 & 807,84 \\
\hline & 5 & 128,10 & 854,03 \\
\hline & 6 & 121,33 & 970,71 \\
\hline \multirow{5}{*}{$M 734^{2}$} & 2 & 238,55 & 636,15 \\
\hline & 3 & 181,77 & 727,09 \\
\hline & 4 & 161,76 & 862,74 \\
\hline & 5 & 161,45 & 1076,38 \\
\hline & 6 & 130,08 & 1040,70 \\
\hline
\end{tabular}

1 - Estádio $R_{7}$

2 - Estádio $R_{8}$.

A variação temporal do acúmulo de massa seca para Cargill 11 e Morgan 734 (Figuras 8 e 9) não apresentaram uma tendência sigmoidal, comum a esta característica, indicando que durante o desenvolvimento de aquênios, o acúmulo de massa seca pelas plantas de girassol não paralisou. Com exceção de Morgan 734 na densidade de 6 plantas $\mathrm{m}^{-1}$, que apresentou estabilização no acúmulo de massa seca a partir da antese (Figura 9).

A produção máxima de massa seca ocorreu no periodo entre o final do florescimento e o desenvolvimento inicial de aquênios, atingindo $1095,38 \mathrm{~g} \mathrm{~m}^{-2}$ para Morgan 734 e, $970,71 \mathrm{~g} \mathrm{~m}^{-2}$ para Cargill 11. Esses valores são inferiores aos $1350 \mathrm{~g} \mathrm{~m}^{-2}$, referente a produção final de massa seca dos hibridos Dekalb G100 e Topflor encontrado por Andrade (1995), trabalhando na densidade de 6,7 plantas $m^{-2}$. 
Alguns autores, Blanchet e Merrien (1981) ${ }^{5}$ citado por Ungaro et al. (1985) e, Rawson e Constable (1980), observaram queda no acúmulo de massa seca total no início do período de enchimento de grãos, que segundo os autores, pode ocorrer porque os fotossintetizados são transformados principalmente em óleo e proteína, o que reflete em grande uso de energia para a respiração, já que a produção de óleo exige maior custo energético, e também porque na planta de girassol há um envelhecimento precoce do aparato foliar, que o torna menos ativo no início do florescimento.

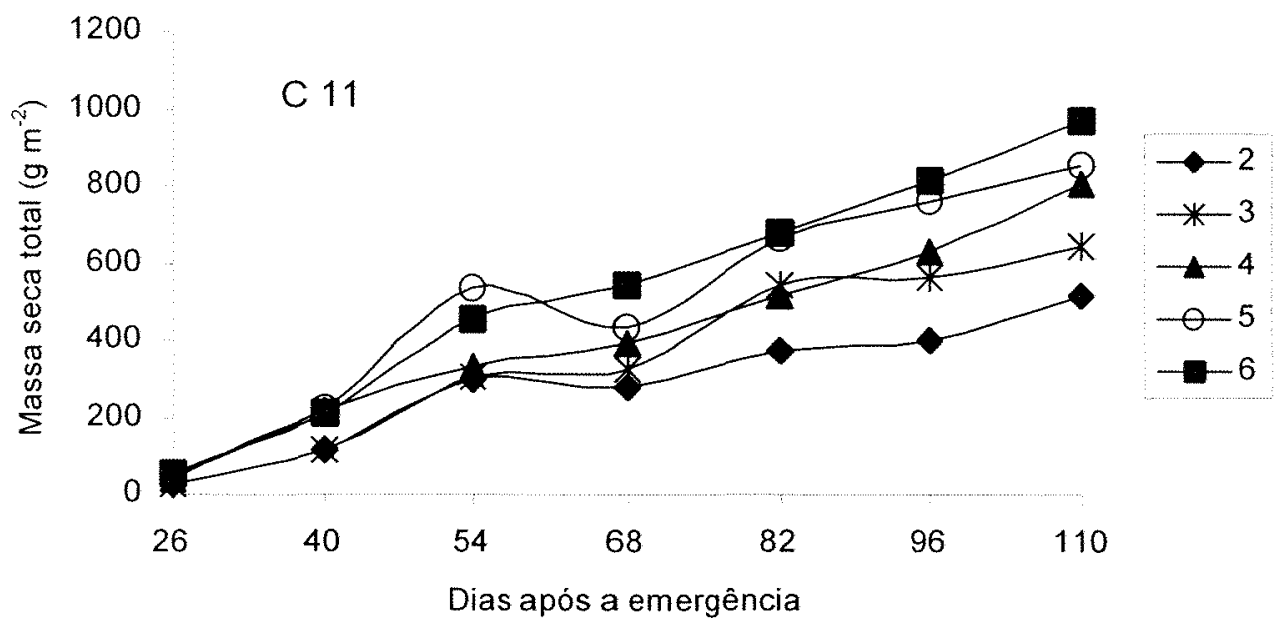

Figura 8 - Variação da massa seca total $\left(\mathrm{g} \mathrm{m}^{-2}\right)$ do cultivar de girassol Cargill 11 , nas densidades de $2,3,4,5$ e 6 plantas por metro, em época de semeadura safrinha.

\footnotetext{
${ }^{5}$ BLANCHET, R.; MERRIEN, A. Quelques aspects de la physiologie du tournesol. Boletim CETIOM, v. 80, p. 5-7, 1981.
} 


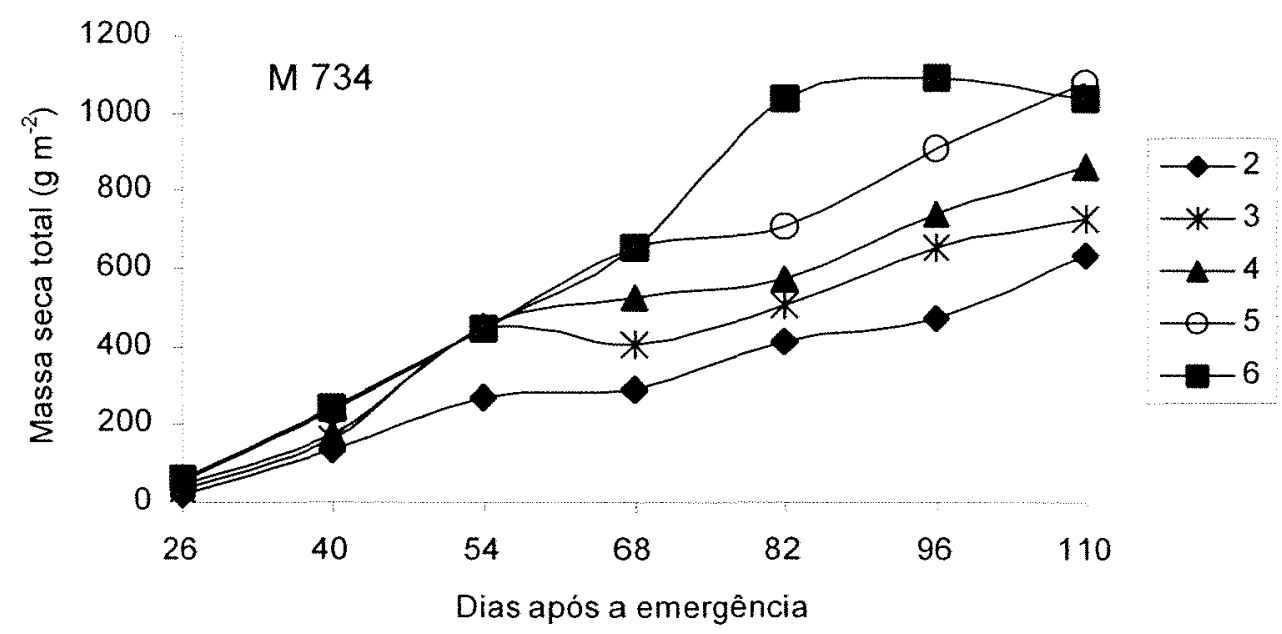

Figura 9 - Variação da massa seca total $\left(\mathrm{g} \mathrm{m}^{-2}\right)$ do cultivar de girassol, Morgan 734 , nas densidades de 2, 3, 4, 5 e 6 plantas por metro, em época de semeadura safrinha.

\subsection{2 Índice de área foliar (IAF)}

Índices de área foliar observados para cultivares de girassol, em cinco diferentes densidades de plantas na linha e semeados na época de semeadura safrinha, são apresentados nas Tabelas 17 a 23. De acordo com a análise de variância apresentada no Apêndice $B$, as variações no índice de área foliar (IAF) não apresentaram diferenças significativas entre cultivares, em todas as fases fenológicas, assim como não houve interação entre os fatores cultivar e densidade, constatado pelo teste de comparações de médias.

A análise de regressão polinomial não revelou efeito significativo para o fator densidade, em todas as fases fenológicas, indicando que a variação no IAF não permitiu qualidade de ajuste para modelos de regressão. A exceção ocorreu no estádio $R_{2}$, no qual o IAF aumentou significativamente de forma linear (Anexo B), mostrando que o aumento de uma planta na densidade ocasiona aumento significativo de 0,0026 no IAF original (Figura 10). Este resultado concorda com 
Cardinali et al. (1985) e Carvalho et al. (1991-95), que verificaram incrementos no IAF com aumento da população de plantas, em pleno florescimento.

Tabela 17. Índice de área foliar $\left(\mathrm{m}^{2} \mathrm{~m}^{-2}\right)$ de cultivares de girassol no estádio $V_{12}$, manejados sob diferentes densidades de plantas, em época de semeadura safrinha

\begin{tabular}{ccccccc}
\hline \multirow{2}{*}{ Cultivares } & \multicolumn{7}{c}{ Densidades $\left(\right.$ plantas $\mathrm{m}^{-1}$ ) } & \multirow{2}{*}{ Médias } \\
\cline { 2 - 6 } & 2 & 3 & 4 & 5 & 6 & \\
\hline C 11 & $1,69^{1}$ & 1,94 & 2,05 & 1,97 & 1,91 & $1,91 \mathrm{a}$ \\
M 734 & 1,77 & 2,01 & 1,91 & 1,86 & 2,02 & $1,92 \mathrm{a}$ \\
\hline Média & 1,73 & 1,98 & 1,98 & 1,92 & 1,97 & \\
\hline D.M.S. $^{2}$ & 0,06 & & C.V. (\%) & 4,87 & &
\end{tabular}

${ }^{1} \mathrm{Na}$ tabela encontram-se os valores originais, mas para fins de análise os dados foram transformados segundo $\sqrt{x+0,5}$

${ }^{2}$ Diferença mínima significativa obtida dos dados transformados.

Tabela 18. Índice de área foliar $\left(\mathrm{m}^{2} \mathrm{~m}^{-2}\right)$ de cultivares de girassol no estádio $V_{21}$, manejados sob diferentes densidades de plantas, em época de semeadura safrinha

\begin{tabular}{|c|c|c|c|c|c|c|}
\hline \multirow{2}{*}{ Cultivares } & \multicolumn{5}{|c|}{ Densidades (plantas $\mathrm{m}^{-1}$ ) } & \multirow{2}{*}{ Médias } \\
\hline & 2 & 3 & 4 & 5 & 6 & \\
\hline C 11 & $1,93^{1}$ & 2,04 & 2,25 & 2,42 & 2,29 & $2,18 \mathrm{a}$ \\
\hline M 734 & 1,99 & 1,96 & 2,03 & 2,22 & 2,05 & $2,04 a$ \\
\hline Média & 1,96 & 2,00 & 2,14 & 2,32 & 2,17 & \\
\hline $\begin{array}{l}\text { D.M.S. }{ }^{2} \\
\mathrm{Na} \text { tabela } \\
\text { ransformados } \\
\text { Diferenca mi }\end{array}$ & $\begin{array}{l}0,09 \\
\text { tram-se }\end{array}$ & & $\begin{array}{l}\text { C.V. }(\%) \\
\text { jinais, }\end{array}$ & $\begin{array}{l}6,94 \\
\text { ra fins }\end{array}$ & & \\
\hline
\end{tabular}


Tabela 19. Índice de área foliar $\left(\mathrm{m}^{2} \mathrm{~m}^{-2}\right)$ de cultivares de girassol no estádio $R_{2}$, manejados sob diferentes densidades de plantas, em época de semeadura safrinha

\begin{tabular}{ccccccc}
\hline \multirow{2}{*}{ Cultivares } & \multicolumn{7}{c}{ Densidades $\left(\right.$ plantas $\mathrm{m}^{-1}$ ) } & \multirow{2}{*}{ Médias } \\
\cline { 2 - 6 } & 2 & 3 & 4 & 5 & 6 & \\
\hline C 11 & $3,26^{1}$ & 2,99 & 3,49 & 3,79 & 3,87 & 3,48 a \\
M 734 & 3,06 & 4,09 & 3,56 & 3,71 & 4,29 & 3,73 a \\
\hline Média & 3,16 & 3,53 & 3,52 & 3,75 & 4,08 & \\
\hline D.M.S. $^{2}$ & 0,09 & & C.V. (\%) & 6,18 & &
\end{tabular}

${ }^{1} \mathrm{Na}$ tabela encontram-se os valores originais, mas para fins de análise os dados foram transformados segundo $\sqrt{x+0,5}$.

${ }^{2}$ Diferença mínima significativa obtida dos dados transformados.

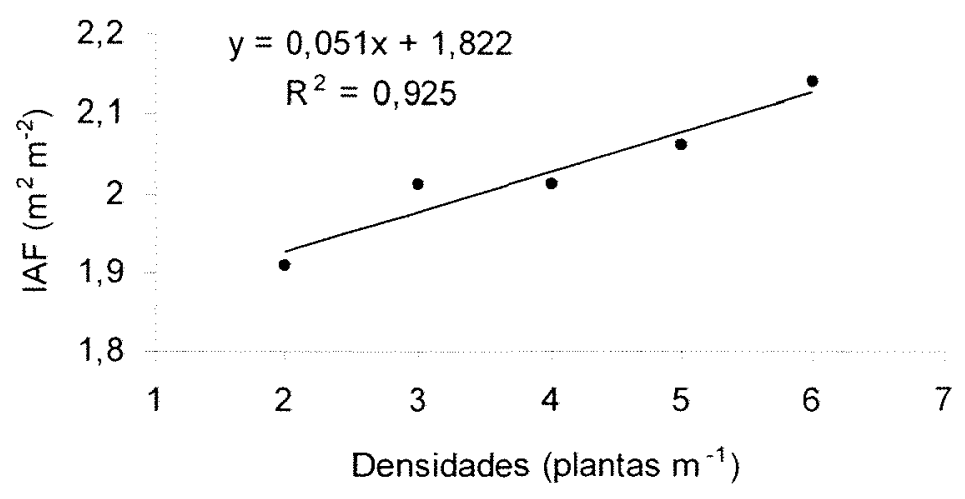

Figura 10 - Índice de área foliar $\left(\mathrm{m}^{2} \mathrm{~m}^{-2}\right)$ dos cultivares de girassol C 11 e $\mathrm{M} 734$, no estádio $R_{2}$, em função das densidades de plantas na linha em época de semeadura safrinha. 
Tabela 20. Índice de área foliar $\left(\mathrm{m}^{2} \mathrm{~m}^{-2}\right)$ dos cultivares de girassol C 11 e M 734, nos estádios $R_{4}$ e $R_{5.1}$ respectivamente, manejados sob diferentes densidades de plantas, em época de semeadura safrinha

\begin{tabular}{|c|c|c|c|c|c|c|}
\hline \multirow{2}{*}{ Cultivares } & \multicolumn{5}{|c|}{ Densidades (plantas $\mathrm{m}^{-1}$ ) } & \multirow{2}{*}{ Médias } \\
\hline & 2 & 3 & 4 & 5 & 6 & \\
\hline C 11 & $4,10^{1}$ & 4,12 & 4,04 & 3,86 & 2,92 & $3,79 a$ \\
\hline M 734 & 3,28 & 3,36 & 3,68 & 4,24 & 3,85 & 3,67 a \\
\hline Média & 3,68 & 3,73 & 3,86 & 4,05 & 3,37 & \\
\hline $\begin{array}{c}\text { D.M.S. }{ }^{2} \\
{ }^{2} \mathrm{Na} \text { tabela }\end{array}$ & $\begin{array}{l}0,16 \\
\text { ontram-s } \\
\text { gundo }\end{array}$ & & $\begin{array}{l}\text { C.V. (\%) } \\
\text { jinais, me }\end{array}$ & $\begin{array}{l}10,28 \\
\text { ra fins }\end{array}$ & & dos for \\
\hline
\end{tabular}

Tabela 21. Índice de área foliar $\left(\mathrm{m}^{2} \mathrm{~m}^{-2}\right)$ dos cultivares de girassol C 11 e $M 734$, nos estádios $R_{5.6}$ e $R_{5.8}$ respectivamente, manejados sob diferentes densidades de plantas, em época de semeadura safrinha

\begin{tabular}{|c|c|c|c|c|c|c|}
\hline \multirow{2}{*}{ Cultivares } & \multicolumn{5}{|c|}{ Densidades (plantas $\mathrm{m}^{-1}$ ) } & \multirow{2}{*}{ Médias } \\
\hline & 2 & 3 & 4 & 5 & 6 & \\
\hline C 11 & $3,39^{1}$ & 3,26 & 2,55 & 3,23 & 2,56 & $2,99 a$ \\
\hline M 734 & 2,40 & 3,35 & 3,02 & 3,00 & 3,57 & $3,05 a$ \\
\hline Média & 2,88 & 3,30 & 2,78 & 3,11 & 3,05 & \\
\hline $\begin{array}{l}\text { D.M.S. }{ }^{2} \\
{ }^{1} \mathrm{Na} \text { tabela } \\
\text { transformado }\end{array}$ & $\begin{array}{c}0,14 \\
\text { ntram-s } \\
\text { jundo }\end{array}$ & $\frac{\text { valores }}{5}$ & $\begin{array}{l}C . V .(\%) \\
\text { jinais, ma }\end{array}$ & $\begin{array}{l}9,07 \\
\text { ra fins }\end{array}$ & & lados fol \\
\hline
\end{tabular}


Tabela 22. Índice de área foliar $\left(\mathrm{m}^{2} \mathrm{~m}^{-2}\right)$ de cultivares de girassol no estádio $R_{6}$, manejados sob diferentes densidades de plantas, em época de semeadura safrinha

\begin{tabular}{|c|c|c|c|c|c|c|}
\hline \multirow{2}{*}{ Cultivares } & \multicolumn{5}{|c|}{ Densidades (plantas $\mathrm{m}^{-1}$ ) } & \multirow{2}{*}{ Médias } \\
\hline & 2 & 3 & 4 & 5 & 6 & \\
\hline C 11 & $2,31^{1}$ & 2,29 & 2,47 & 2,38 & 2,74 & $2,44 a$ \\
\hline M 734 & 2,70 & 2,34 & 2,60 & 2,52 & 2,47 & $2,53 a$ \\
\hline Média & 2,50 & 2,31 & 2,53 & 2,45 & 2,61 & \\
\hline $\begin{array}{l}\text { D.M.S. }{ }^{2} \\
{ }^{1} \mathrm{Na} \text { tabela } \\
\text { transformado }\end{array}$ & $\begin{array}{l}0,06 \\
\text { ntram-s } \\
\text { jundo }\end{array}$ & valores & $\begin{array}{l}\text { C.V. }(\%) \\
\text { inais, ma }\end{array}$ & $\begin{array}{l}4,91 \\
\text { ara fins }\end{array}$ & álise & ados foran \\
\hline
\end{tabular}

Tabela 23. Índice de área foliar $\left(\mathrm{m}^{2} \mathrm{~m}^{-2}\right)$ dos cultivares de girassol C 11 e $M 734$, nos estádios $R_{7}$ a $R_{8}$ respectivamente, manejados sob diferentes densidades de plantas, em época de semeadura safrinha

\begin{tabular}{|c|c|c|c|c|c|c|}
\hline \multirow{2}{*}{ Cultivares } & \multicolumn{5}{|c|}{ Densidades (plantas $\mathrm{m}^{-1}$ ) } & \multirow{2}{*}{ Médias } \\
\hline & 2 & 3 & 4 & 5 & 6 & \\
\hline C 11 & $1,04^{1}$ & 1,12 & 1,39 & 1,41 & 1,40 & $1,27 \mathrm{a}$ \\
\hline M 734 & 1,07 & 1,28 & 1,33 & 1,32 & 1,18 & $1,23 \mathrm{a}$ \\
\hline Média & 1,06 & 1,20 & 1,36 & 1,37 & 1,29 & \\
\hline $\begin{array}{c}\text { D.M.S. } \\
\\
\\
\mathrm{Na} \text { tabela }\end{array}$ & $\begin{array}{l}0,08 \\
\text { ntram-s } \\
\text { gundo }\end{array}$ & & $\begin{array}{l}C . V .(\%) \\
\text { inais, ma }\end{array}$ & $\begin{array}{l}7,88 \\
\text { ra fins }\end{array}$ & & dos $\mathrm{fo}$ \\
\hline
\end{tabular}

Os valores máximos de índice de área foliar, foram $4,12 \mathrm{~m}^{2} \mathrm{~m}^{-2}$ para Cargill $11\left(3\right.$ plantas $\left.\mathrm{m}^{-1}\right)$ e, 4,29 $\mathrm{m}^{2} \mathrm{~m}^{-2}$ para Morgan $734\left(6\right.$ plantas $\left.\mathrm{m}^{-1}\right)$, atingidos durante os estádios $R_{4}$ e $R_{2}$, respectivamente. Posteriormente, o IAF decresceu em função da senescência das folhas mais velhas, resultando numa tendência parabólica para todas as curvas (Figuras 11 e 12) que descrevem essa relação. 
Estes resultados assemelham-se aos obtidos por Jaafar et al. (1993) no final do periodo de abertura do botão floral.

Observou-se também que Cargill 11 quando conduzido na densidade de 6 plantas $\mathrm{m}^{-1}$, apresentou um rápido decréscimo no IAF logo após atingir seu pico em $R_{2}$ (Figura 11), possivelmente devido ao autosombreamento causado pelas folhas superiores sobre as inferiores resultando em senescência precoce. Este desempenho pode ser comprovado por Aguirrezábal et al. (1987) que observaram um atraso para a máxima superfície foliar ser atingida na menor densidade de plantas.

Com o aumento do IAF, as folhas inferiores são mais sombreadas, diminuindo a taxa fotossintética de toda a área foliar (Lucchesi, 1984). Para Daughtry $(1992)^{6}$ citado por Barni et al. (1995a), dosséis com os mais baixos valores sazonais de IAF, geralmente absorvem menor quantidade de radiação solar fotossinteticamente ativa, produzem menor quantidade de fitomassa e apresentam os menores rendimentos de grãos.

${ }^{6}$ DAUGHTRY, C. S. T.; GALLO, K. P.; GOWARD, S. N.; PRINCE, S. D.; KUSTAS, W. P. Spectral estimates of absorbed radiation and phytomass production in corn and soybean canopies. Remote Sensing Environment, v. 39, p. 141-152, 1992. 


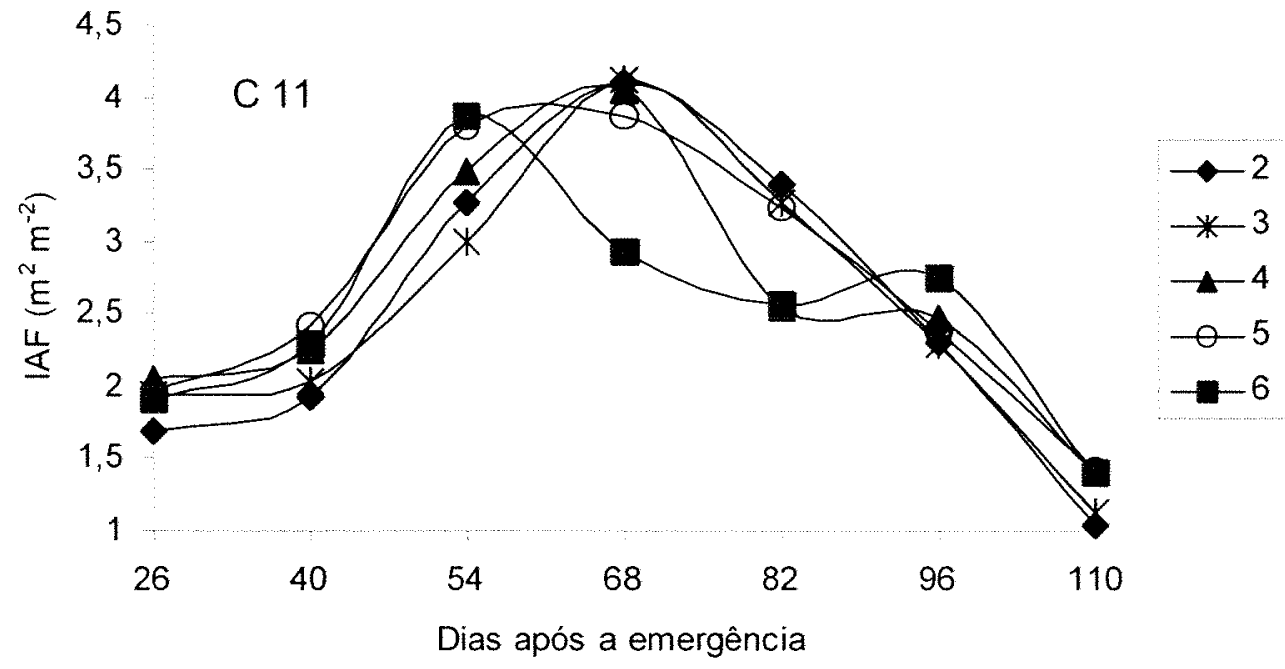

Figura 11 - Variação do índice de área foliar $\left(\mathrm{m}^{2} \mathrm{~m}^{-2}\right)$ de girassol, cultivar Cargill 11 , nas densidades de 2, 3, 4, 5 e 6 plantas por metro, em época de semeadura safrinha.

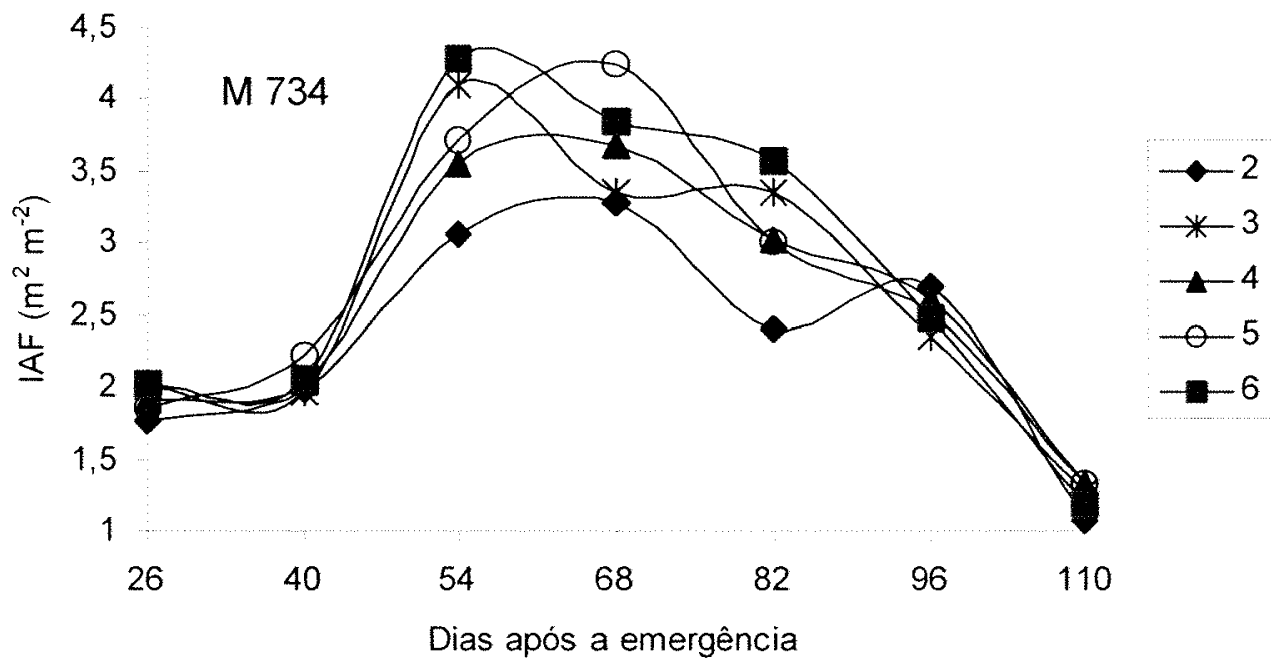

Figura 12 - Variação do indice de área foliar $\left(\mathrm{m}^{2} \mathrm{~m}^{-2}\right)$ de girassol, cultivar Morgan 734 , nas densidades de 2, 3, 4, 5 e 6 plantas por metro, em época de semeadura safrinha. 


\subsubsection{Taxa de crescimento da cultura (TCC)}

Os valores de taxa de crescimento da cultura máximos e minimos, e os respectivos dias após a emergência em que ocorreram, para cultivares de girassol manejados sob cinco densidades de plantas, em época de semeadura safrinha, são apresentados na Tabela 24. Para cada planta a mais na linha, verificou-se aumento na taxa de crescimento da cultura, até a metade da antese, com valores de $13,4 \mathrm{~g} \mathrm{~m}^{-2}$ para Cargill 11 e $21,7 \mathrm{~g} \mathrm{~m}^{-2}$ para Morgan 734 , ambos na densidade de 6 plantas $\mathrm{m}^{-1}$, inferiores aos encontrados por Andrade (1995). Desse modo, pode-se afirmar que as densidades mais altas apresentaram maior capacidade de produção de fitomassa, em virtude do maior número de plantas presentes por unidade de área, do que em densidades mais baixas.

Considerando-se todas as densidades e cultivares, observa-se pelas Figuras 13 e 14 , que os valores máximos de taxa de crescimento da cultura ocorreram durante o período compreendido entre o desenvolvimento do botão floral e o início da antese. À exceção ocorreu para Cargill 11 na densidade de 4 plantas $\mathrm{m}^{-1}$ (Figura 13) e para Morgan 734 na densidade de 2 plantas $\mathrm{m}^{-1}$ (Figura 14), que apresentaram pico máximo na metade da antese. A partir desse momento, reduções na taxa de crescimento da cultura foram observadas para todas as densidades. Barni et al. (1995b) também observaram decréscimos na TCC, a partir do estádio de diferenciação do primórdio floral $\left(R_{1}\right)$, quando a planta utilizou suas energias para o início do período reprodutivo. 
Tabela 24. Valores mínimo e máximo para taxa de crescimento da cultura dos cultivares de girassol C 11 e M 734 e respectivo números de dias após a emergência (DAE) em que ocorreram, em função da densidades de plantas na linha, em época de semeadura safrinha

\begin{tabular}{cccccc}
\hline \multirow{2}{*}{ Cultivares } & Densidades & \multicolumn{4}{c}{ Taxa de Crescimento da Cultura $\left(\mathrm{g} \mathrm{m}^{-2}\right)$} \\
\cline { 2 - 6 } & $\left(\right.$ plantas $\left.\mathrm{m}^{-1}\right)$ & Mínima & DAE & Máxima & DAE \\
\hline \multirow{4}{*}{ C 11 } & 2 & 1,553 & 110 & 6,839 & 59 \\
& 3 & 1,997 & 110 & 10,384 & 63 \\
& 4 & 3,894 & 26 & 10,050 & 79 \\
& 5 & 2,562 & 110 & 11,757 & 58 \\
& 6 & 3,892 & 110 & 13,476 & 64 \\
& 2 & 2,915 & 26 & 7,917 & 80 \\
& 3 & 2,387 & 110 & 10,143 & 60 \\
& 4 & 2,953 & 110 & 12,083 & 62 \\
& 4 & 4,972 & 110 & 14,848 & 66 \\
& 5 & 1,780 & 110 & 21,702 & 60 \\
\hline
\end{tabular}

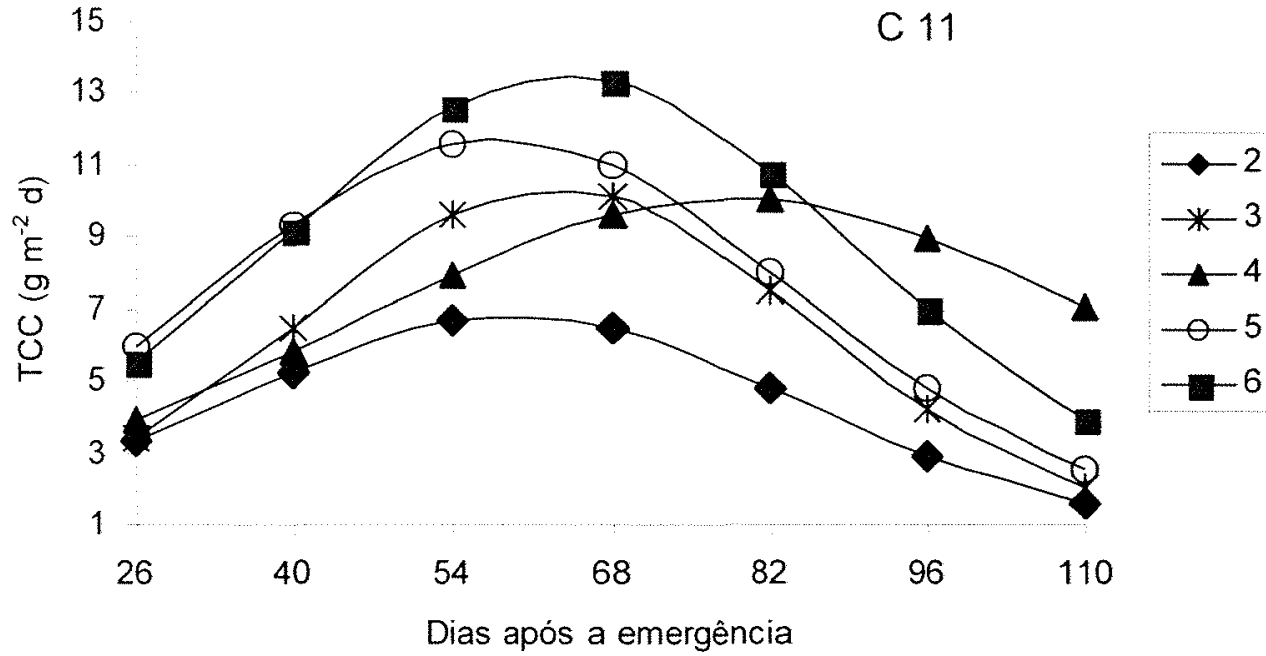

Figura 13 - Taxa de crescimento da cultura $\left(\mathrm{g} \mathrm{m}^{-2}\right)$ do cultivar de girassol $\mathrm{C} 11$, nas densidades de 2, 3, 4, 5 e 6 plantas por metro de linha, em época de semeadura safrinha. 


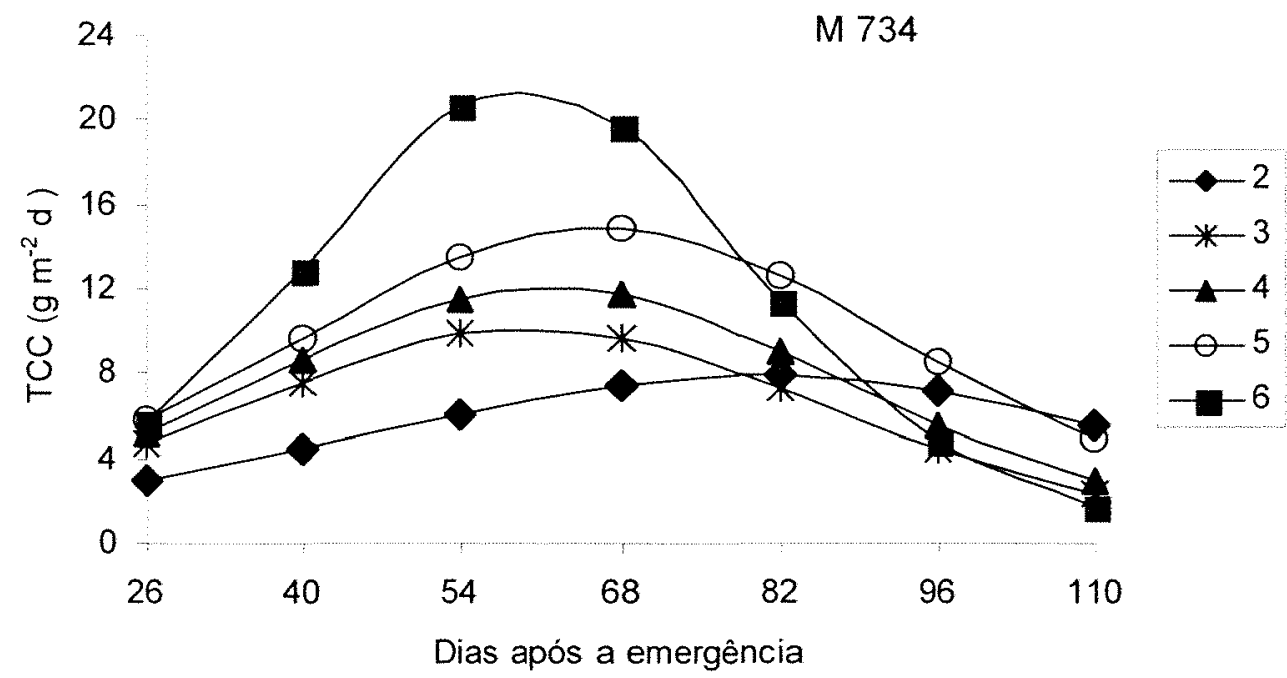

Figura 14 - Taxa de crescimento da cultura $\left(\mathrm{g} \mathrm{m}^{-2}\right)$ do cultivar de girassol $\mathrm{M} 734$, nas densidades de 2, 3, 4, 5 e 6 plantas por metro de linha, em época de semeadura safrinha.

\subsubsection{Taxa de crescimento relativo (TCR)}

Os resultados apresentados na Tabela 25, indicam que a taxa de crescimento relativo é alta no início do ciclo vegetativo, devido ao aumento na velocidade da capacidade fotossintética, o que concorda com Ungaro et al. (1985), Pérez Nieto et al. (1992) e Barni et al. (1995b), apresentando rápido decréscimo a partir do desenvolvimento do botão floral (Figuras 15 e 16). Esse decréscimo pode ser atribuído ao incremento acumulativo de massa seca, sendo a maior parte de sua energia utilizada para o florescimento. $O$ autosombreamento também pode contribuir para a queda na TCR. Morgan 734 na densidade de 6 plantas $\mathrm{m}^{-1}$ (Figura 16), apresentou um decréscimo mais acentuado que as demais densidades, devido ao autosombreamento causado pelo elevado IAF, 4,29 $\mathrm{m}^{2} \mathrm{~m}^{-2}$ (Tabela 19), prejudicando o acúmulo de massa seca. Ungaro et al. (1985) observaram desempenho semelhante para o cv. Anhandy no cultivo de verão.

Em relação ao fator densidade, a TCR apresentou um desempenho diferenciado dentro de cada cultivar. Observa-se que até o início da antese, aos 68 
dias após a emergência, Cargill $11 \mathrm{com} 3$ plantas $\mathrm{m}^{-1}$ e Morgan 734 com 6 plantas $\mathrm{m}^{-1}$ apresentaram maior eficiência em acumular massa seca, que as demais densidades. Após essa fase, os maiores valores para TCR foram observados Cargill 11 com 4 plantas $\mathrm{m}^{-1}$ e Morgan 734 com 2 plantas $\mathrm{m}^{-1}$.

Tabela 25. Valores mínimo e máximo para taxa de crescimento relativo dos cultivares de girassol C 11 e $M 734$ e respectivo números de dias após a emergência (DAE) em que ocorreram, em função da densidades de plantas na linha, em época de semeadura safrinha

\begin{tabular}{cccccc}
\hline \multirow{2}{*}{ Cultivares } & Densidades & \multicolumn{4}{c}{ Taxa de Crescimento Relativo $\left(\mathrm{g} \mathrm{g}^{-1} \mathrm{dia}^{-1}\right)$} \\
\cline { 3 - 6 } & (plantas $\left.\mathrm{m}^{-1}\right)$ & Mínima & DAE & Máxima & DAE \\
\hline \multirow{4}{*}{ C 11 } & 2 & 0,003 & 110 & 0,046 & 26 \\
& 3 & 0,003 & 110 & 0,056 & 26 \\
& 4 & 0,009 & 110 & 0,035 & 26 \\
& 5 & 0,003 & 110 & 0,046 & 26 \\
& 6 & 0,004 & 110 & 0,047 & 26 \\
M 734 & 2 & 0,009 & 110 & 0,036 & 26 \\
& 3 & 0,003 & 110 & 0,047 & 26 \\
& 4 & 0,004 & 110 & 0,048 & 26 \\
& 5 & 0,005 & 110 & 0,046 & 26 \\
& 6 & 0,002 & 110 & 0,071 & 26 \\
\hline
\end{tabular}




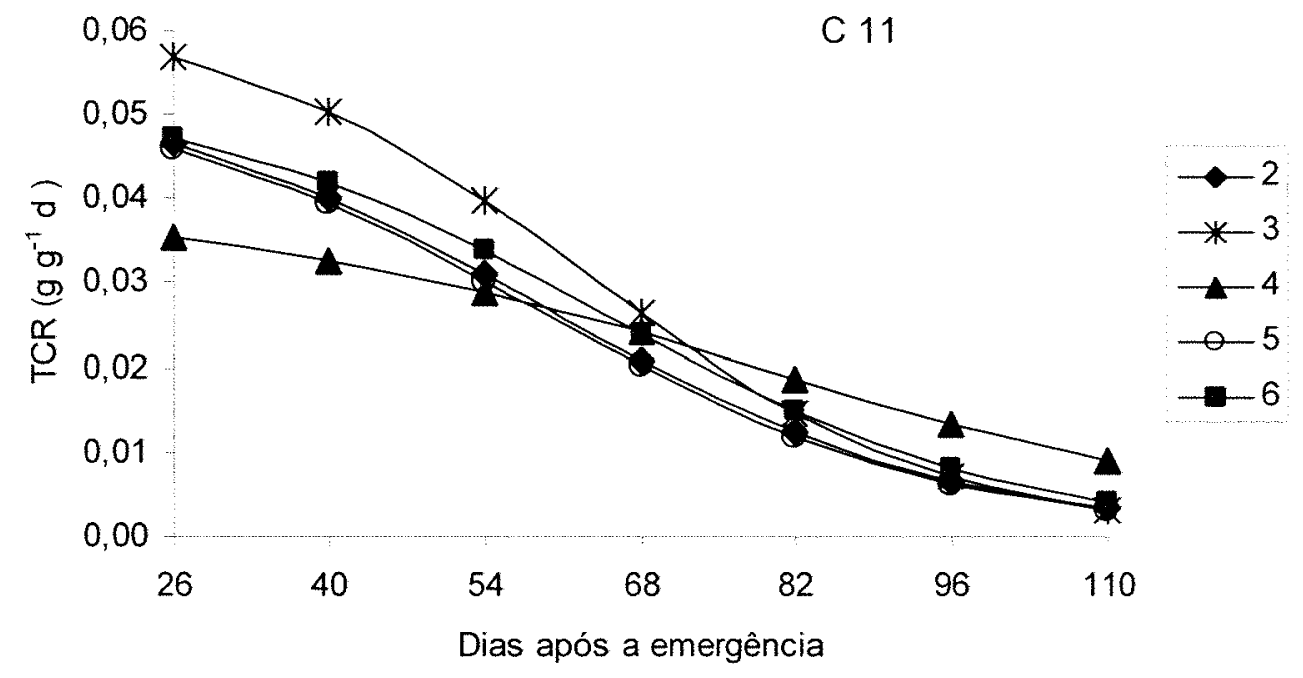

Figura 15 - Taxa de crescimento relativo $\left(\mathrm{g} \mathrm{g}^{-1} \mathrm{dia}^{-1}\right)$ do cultivar de girassol C 11 , nas densidades de 2, 3, 4, 5 e 6 plantas por metro de linha, em época de semeadura safrinha.

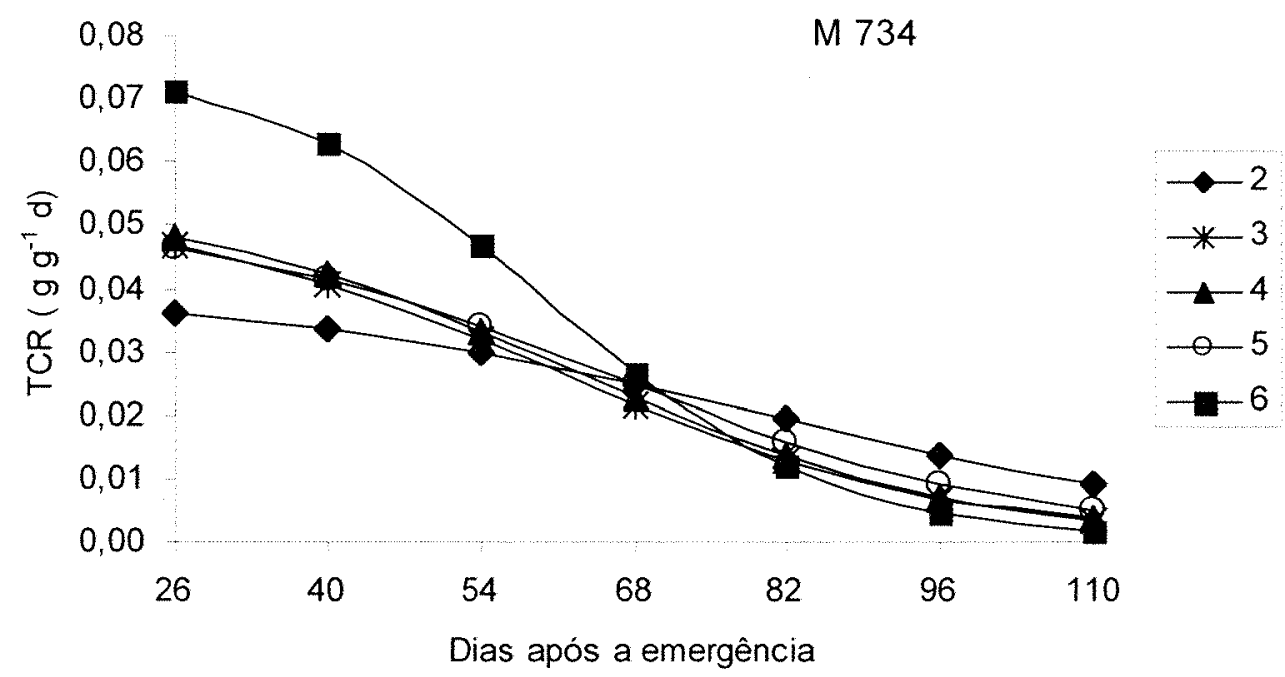

Figura 16 - Taxa de crescimento relativo $\left(\mathrm{g} \mathrm{g}^{-1} \mathrm{dia}^{-1}\right)$ do cultivar de girassol $\mathrm{M} 734$, nas densidades de 2, 3, 4, 5 e 6 plantas por metro de linha, em época de semeadura safrinha. 


\subsubsection{Taxa assimilatória líquida (TAL)}

Os valores mínimo e máximo de taxa de assimilação líquida e os respectivos dias após a emergência para sua ocorrência, para cultivares de girassol, manejados sob cinco densidades de plantas, em época de semeadura safrinha, são apresentados na Tabela 26. A taxa assimilatória líquida foi máxima durante o período vegetativo até o início da fase reprodutiva, estando de acordo com Ungaro et al. (1985) e Pérez Nieto et al. (1992), podendo estar associado à demanda de produtos fotossintetizados pelos sítios de consumo, como novas folhas e diferenciação do botão floral, decrescendo gradativamente após o florescimento, devido ao aumento do autosombreamento.

Algumas exceções ocorreram, como por exemplo, para Cargill 11 na densidade de 4 plantas $\mathrm{m}^{-1}$ (Figura 17) e Morgan $734 \mathrm{com} 2$ plantas $\mathrm{m}^{-1}$ (Figura 18), que apresentaram elevação na TAL a partir dos $68 \mathrm{DAE}$, quando, provavelmente ocorreu uma nova produção de assimilados para o enchimento de aquênios. Morgan 734 na densidade de 5 plantas $\mathrm{m}^{-1}$ (Figura 18), também apresentou um desempenho diferenciado, com valores praticamente constantes de TAL durante todo o período experimental.

Para cada cultivar, verificou-se que o aumento na densidade de plantas na linha resultou em decréscimos na taxa assimilatória líquida, atribuído ao autosombreamento decorrente do fechamento mais rápido da cultura, nas maiores densidades. 
Tabela 26. Valores mínimo e máximo para taxa assimilatória líquida dos cultivares de girassol C 11 e M 734 e respectivo números de dias após a emergência (DAE) em que ocorreram, em função da densidades de plantas na linha, em época de semeadura safrinha

\begin{tabular}{|c|c|c|c|c|c|}
\hline \multirow{2}{*}{ Cultivares } & \multirow{2}{*}{$\begin{array}{l}\text { Densidades } \\
\text { (plantas } \mathrm{m}^{-1} \text { ) }\end{array}$} & \multicolumn{4}{|c|}{ Taxa assimilatória líquida $\left(\mathrm{g} \mathrm{m}^{-2} \mathrm{dia}^{-1} \mathrm{IAF}\right)$} \\
\hline & & Mínima & DAE & Máxima & DAE \\
\hline \multirow{5}{*}{ C 11} & 2 & 1,285 & 105 & 2,807 & 26 \\
\hline & 3 & 1,559 & 110 & 2,874 & 49 \\
\hline & 4 & 2,236 & 47 & 5,408 & 110 \\
\hline & 5 & 1,903 & 110 & 3,619 & 26 \\
\hline & 6 & 2,726 & 110 & 3,927 & 60 \\
\hline \multirow{5}{*}{ M 734} & 2 & 2,009 & 41 & 4,238 & 110 \\
\hline & 3 & 1,813 & 110 & 3,042 & 27 \\
\hline & 4 & 2,071 & 110 & 3,618 & 36 \\
\hline & 5 & 3,634 & 69 & 3,941 & 26 \\
\hline & 6 & 1,391 & 110 & 5,373 & 53 \\
\hline
\end{tabular}

6

C 11

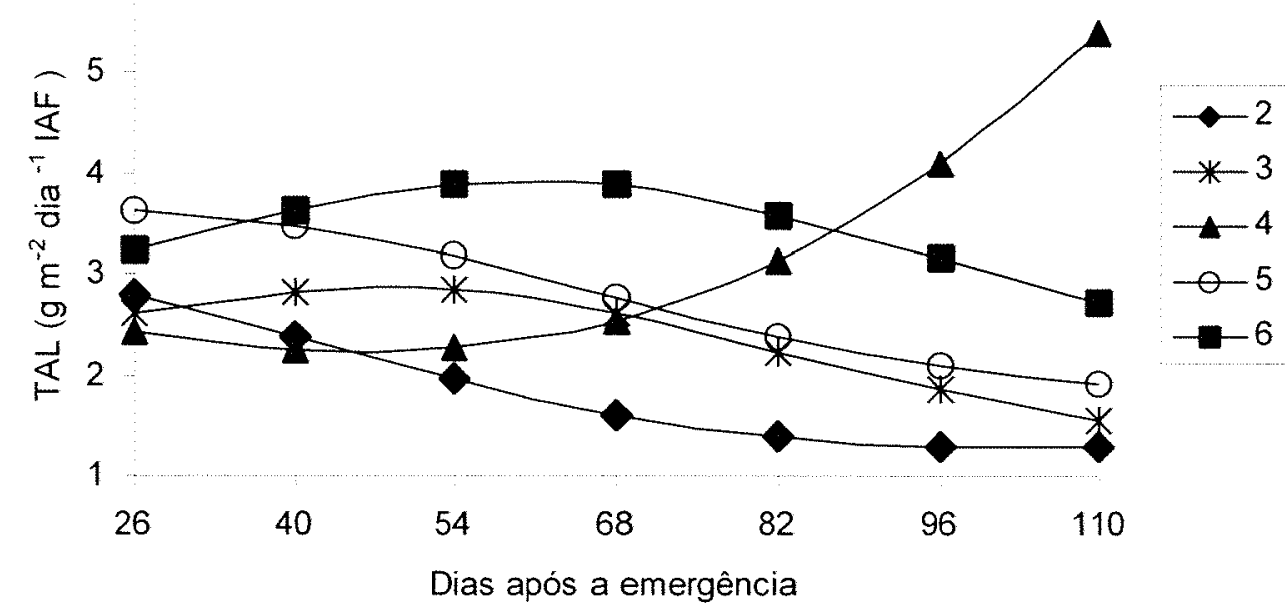

Figura 17 - Taxa assimilatória líquida $\left(\mathrm{g} \mathrm{m}^{-2} \mathrm{dia}^{-1} \mathrm{IAF}\right)$ do cultivar de girassol $\mathrm{C} 11$, nas densidades de 2, 3, 4, 5 e 6 plantas por metro de linha, em época de semeadura safrinha. 


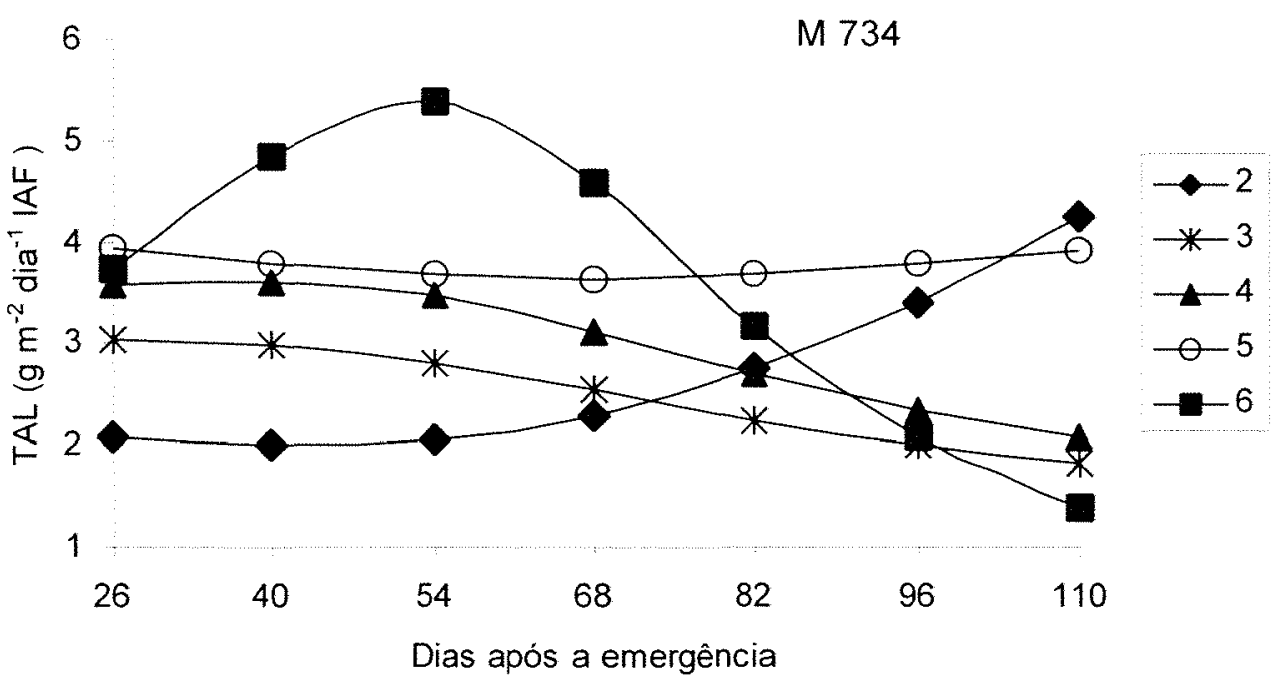

Figura 18 - Taxa assimilatória líquida $\left(\mathrm{g} \mathrm{m}^{-2} \mathrm{dia}^{-1} \mathrm{IAF}\right)$ do cultivar de girassol $\mathrm{M}$ 734 , nas densidades de 2, 3, 4, 5 e 6 plantas por metro de linha, em época de semeadura safrinha.

\subsubsection{Razão de área foliar (RAF)}

Pela Tabela 27, observa-se que os valores máximos de razão de área foliar foram atingidos na densidade de 3 plantas $\mathrm{m}^{-1}$ para Cargill $11\left(0,021 \mathrm{~m}^{2} \mathrm{~g}^{-1}\right)$ e com 6 plantas $\mathrm{m}^{-1}$ para Morgan $734\left(0,019 \mathrm{~m}^{2} \mathrm{~g}^{-1}\right)$, aos 26 dias após a emergência. A razão de área foliar mostrou-se superior no início do periodo vegetativo para todas as densidades e cultivares (Figuras 19 e 20), apresentando maior quantidade de material fotossintetizante em relação a massa seca, decrescendo em seguida, concordando com os resultados obtidos por Barni et al. (1995b). Esse decréscimo, de acordo com Pereira e Machado (1987), ocorre porque a maior parte dos fotoassimilados são convertidos para as folhas, visando maior captação da radiação solar disponivel.

Verificou-se também, que aumento na densidade de plantas na linha reduziu os valores de razão de área foliar, em virtude da menor área foliar útil para interceptação de energia luminosa, nas densidades mais altas, em conseqüência do autosombreamento. 
Tabela 27. Valores mínimo e máximo para razão de área foliar dos cultivares de girassol C 11 e M 734 e respectivo números de dias após a emergência (DAE) em que ocorreram, em função da densidades de plantas na linha, em época de semeadura safrinha

\begin{tabular}{cccccc}
\hline \multirow{2}{*}{ Cultivares } & $\begin{array}{c}\text { Densidades } \\
\left.\text { (plantas } \mathrm{m}^{-1}\right)\end{array}$ & \multicolumn{4}{c}{ Razão de área foliar $\left(\mathrm{m}^{2} \mathrm{~g}^{-1}\right)$} \\
\cline { 3 - 6 } & 2 & 0,003 & 110 & 0,016 & 37 \\
C 11 & 3 & 0,003 & 110 & 0,021 & 26 \\
& 4 & 0,009 & 110 & 0,014 & 33 \\
& 5 & 0,003 & 110 & 0,012 & 26 \\
& 6 & 0,004 & 110 & 0,014 & 26 \\
& 2 & 0,002 & 110 & 0,017 & 26 \\
& 3 & 0,002 & 110 & 0,015 & 26 \\
& 4 & 0,002 & 110 & 0,013 & 26 \\
& 5 & 0,001 & 110 & 0,011 & 26 \\
& 5 & 0,001 & 110 & 0,019 & 26 \\
\hline
\end{tabular}




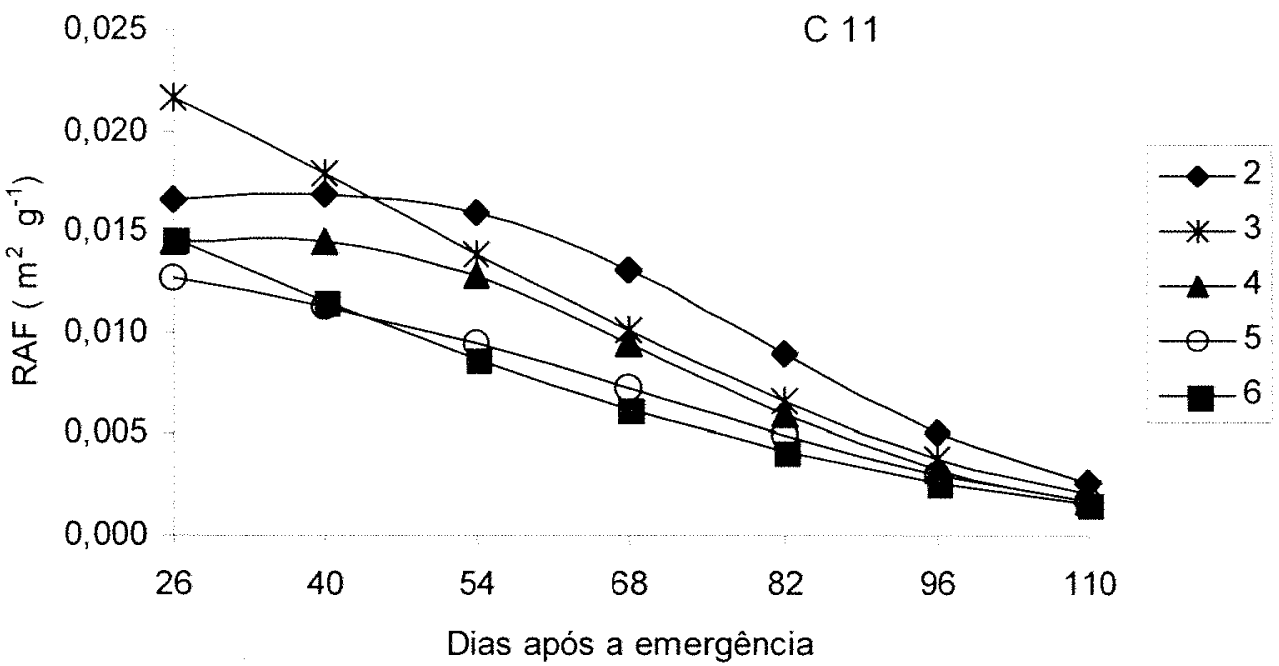

Figura 19 - Razão de área foliar $\left(\mathrm{m}^{2} \mathrm{~g}^{-1}\right)$ do cultivar de girassol $\mathrm{C} 11$, nas densidades de 2, 3, 4, 5 e 6 plantas por metro de linha, em época de semeadura safrinha.

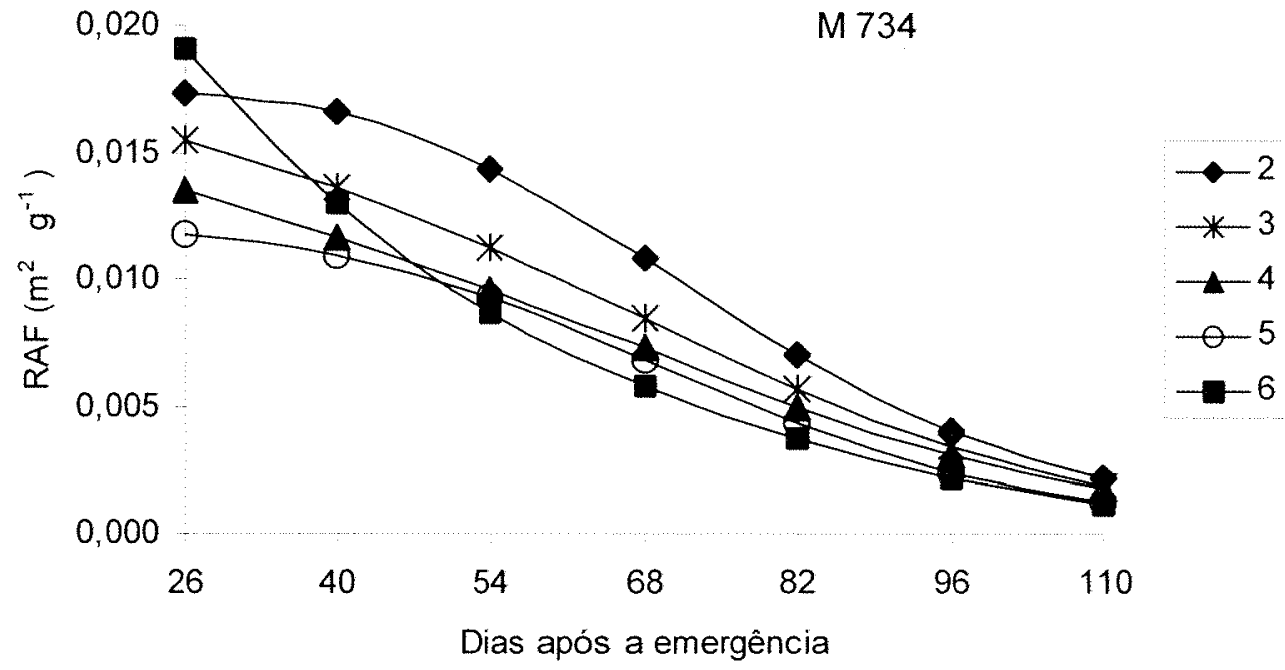

Figura 20 - Razão de área foliar $\left(\mathrm{m}^{2} \mathrm{~g}^{-1}\right)$ do cultivar de girassol $M 734$, nas densidades de 2, 3, 4, 5 e 6 plantas por metro de linha, em época de semeadura safrinha. 


\subsection{7 Índice de colheita (IC)}

Os dados experimentais revelaram índices de colheita entre 0,17 a 0,24 , próximos aos encontrados por Ungaro et al. (1985) e Andrade (1995). Entre cultivares, apesar de Morgan 734 apresentar rendimentos biológicos superiores, este revelou indices de colheita inferiores a Cargill 11 (Tabela 28), reduções estas atribuidas as baixas temperaturas ocorridas durante o florescimento, que afetaram negativamente a produtividade agrícola de Morgan 734.

Em relação ao fator densidade, observa-se uma tendência do índice de colheita decrescer com o aumento do número de plantas na linha, indicando que sob essa condições que propiciam o autosombreamento, desfavorece a conversão de fotoassimilados em produção de aquênios. Em seu estudo, Sobarad et al. (1996) encontraram índice de colheita significativamente superior $(0,28)$, na menor população de plantas.

Tabela 28. Rendimento econômico (RE) e índice de colheita (IC) dos cultivares de girassol, manejados sob diferentes densidades de plantas, em época de semeadura safrinha

\begin{tabular}{cccc}
\hline \multirow{2}{*}{ Cultivares } & Densidades & $\mathrm{RE}$ & IC \\
\cline { 2 - 4 } (plantas $\mathrm{m}^{-1}$ ) & $\mathrm{g} \mathrm{m}^{-2}$ & $\%$ \\
\hline C 11 & 3 & 127,38 & 24 \\
& 4 & 154,75 & 24 \\
& 5 & 197,81 & 24 \\
& 6 & 164,38 & 19 \\
& 2 & 215,58 & 22 \\
M 734 & 3 & 128,16 & 20 \\
& 4 & 128,86 & 18 \\
& 5 & 165,08 & 18 \\
& 6 & 182,84 & 17 \\
& & 197,37 & 19 \\
\hline
\end{tabular}




\subsection{Características agronômicas}

\subsubsection{Número de folhas (NF)}

A análise de variância para número de folhas por planta de girassol, mostrou não haver efeito significativo para a interação cultivar e densidade, revelando que o efeito da densidade é independente do cultivar (Apêndice 3). Mas, no estudo dos efeitos principais, Morgan 734 apresentou em média, maior número de folhas quando comparado a Cargill 11 (Tabela 29). Para Sadras e Villalobos (1993), o genótipo é a principal causa de variação no número total de folhas, e não o meio ambiente.

Entretanto no presente estudo, foi constatado por meio da análise de regressão e através do modelo linear (Figura 21), que aumento da densidade de plantas causa diminuição significativa do número de folhas, devido à competição entre plantas por luz e espaço, favorecendo o crescimento em altura em detrimento da formação de folhas, mostrando que a cada aumento de uma planta ocorre decréscimo, em média, de 0,7 folhas (Anexo C). Tal resultado, discorda de Aguirrezábal et al. (1987) que não encontraram variações no número de folhas de girassol em diferentes densidades populacionais $(35.700,47.600,71.400,95.200$, 143.000 e 286.000 plantas ha ${ }^{-1}$ ). 
Tabela 29. Número de folhas por planta de cultivares de girassol, manejados sob diferentes densidades de plantas, em época de semeadura safrinha

\begin{tabular}{ccccccc}
\hline \multirow{2}{*}{ Cultivares } & \multicolumn{7}{c}{ Densidades (plantas $\mathrm{m}^{-1}$ ) } & \multirow{2}{*}{ Médias } \\
\cline { 2 - 6 } & 2 & 3 & 4 & 5 & 6 & \\
\hline C 11 & 30,07 & 29,67 & 28,60 & 28,07 & 26,07 & $28,49 \mathrm{~b}$ \\
M 734 & 30,60 & 30,60 & 29,33 & 28,87 & 29,20 & 29,72 a \\
\hline Média & 30,33 & 30,13 & 28,97 & 28,47 & 27,63 & \\
\hline D.M.S. & 0,95 & \multicolumn{7}{c}{ C.V. (\%) } & 4,24 & & \\
' Diferença mínima significativa obtida dos dados originais. & & &
\end{tabular}

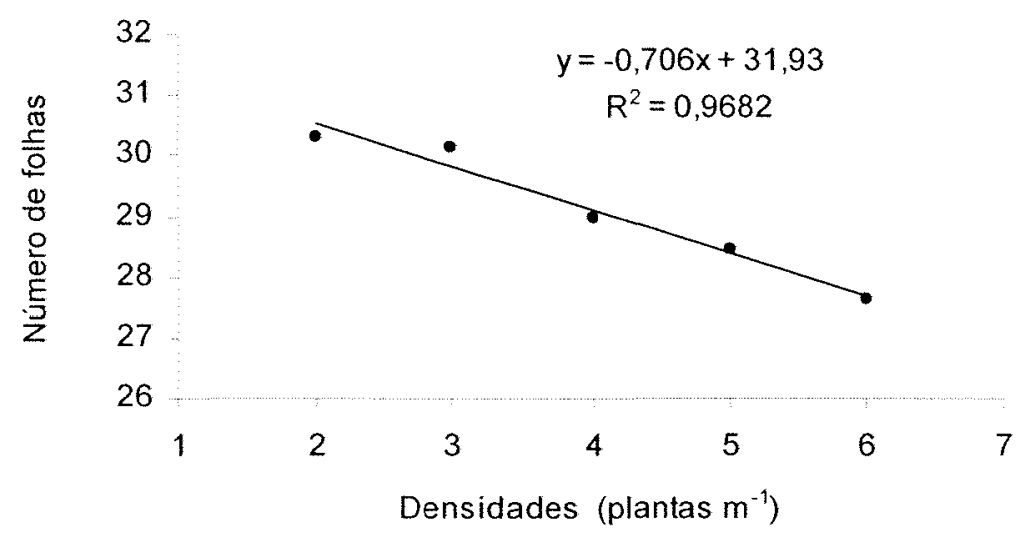

Figura 21 - Número de folhas por planta de girassol dos cultivares C 11 e M 734, em função das densidades de plantas na linha, em época de semeadura safrinha.

\subsubsection{Altura final de planta (AFP)}

Para a variável altura final de planta, a análise de variância mostrou que há interação significativa entre cultivar e densidade, revelando que o efeito da densidade é dependente do cultivar. Comparando-se os cultivares dentro de cada densidade, observa-se que dentro da densidade de 2 plantas por $\mathrm{m}^{-1}$, Morgan 734 , apresentou em média, maior altura final de planta, o que possibilitou a este cultivar, maior produção final de folhas quando comparado a Cargill 11 (Tabela 30). Nas demais densidades $\left(3,4,5\right.$ e 6 plantas por $\left.\mathrm{m}^{-1}\right)$ não foi observada diferença significativa entre os cultivares. 
O desdobramento da análise de regressão para a interação cultivar e densidade revelou efeito linear para Cargill 11, e efeito quadrático para Morgan 734. No entanto, o desempenho desses cultivares para a variável altura final de planta de girassol, não pode ser representado através desses modelos, em virtude dos seus baixos valores de coeficiente de determinação (Anexo $\mathrm{C}$ ).

Tabela 30. Altura final de planta $(\mathrm{cm})$ dos cultivares de girassol, manejados sob diferentes densidades de plantas, em época de semeadura safrinha

\begin{tabular}{|c|c|c|c|c|c|c|}
\hline \multirow{2}{*}{ Cultivares } & \multicolumn{5}{|c|}{ Densidades (plantas $\mathrm{m}^{-1}$ ) } & \multirow{2}{*}{ Médias } \\
\hline & 2 & 3 & 4 & 5 & 6 & \\
\hline C 11 & $156,00 \mathrm{~b}$ & $161,67 \mathrm{a}$ & $169,20 \mathrm{a}$ & 161,47 a & 169,07 a & 163,48 \\
\hline M 734 & $171,40 \mathrm{a}$ & $162,47 \mathrm{a}$ & $160,87 \mathrm{a}$ & $168,07 a$ & 166,93 a & 165,95 \\
\hline Média & 163,70 & 162,07 & 165,03 & 164,77 & 168,00 & \\
\hline $\begin{array}{c}\text { D.M.S. }{ }^{1} \\
\text { Diferença m }\end{array}$ & $\begin{array}{c}8,48 \\
\text { significa }\end{array}$ & & $\begin{array}{l}\text { C.V. (\%) } \\
\text { tos originai }\end{array}$ & 3,00 & & \\
\hline
\end{tabular}

\subsubsection{Diâmetro basal de haste (DH)}

O diâmetro basal de haste variou significativamente com o fator cultivar. Morgan 734 apresentou média significativamente maior diâmetro basal de haste, quando comparado ao cultivar Cargill 11 (Tabela 31), sendo este resultado independente, uma vez que a interação entre fatores foi não significativa.

No estudo de densidade, a análise de regressão polinomial revelou valores de $F$ significativos, cujas variações no diâmetro basal de haste podem ser explicadas pelo modelo quadrático, apresentado no Anexo C. Observa-se que com o aumento do número de plantas na linha, ocorre decréscimo no diâmetro basal de haste, devido à competição entre plantas, apresentando um valor mínimo de diâmetro basal de haste de $2,30 \mathrm{~cm}$ na densidade média de 5,4 plantas $\mathrm{m}^{-1}$ (Figura 22). 
Tabela 31. Diâmetro basal de haste $(\mathrm{cm})$ de cultivares de girassol, manejados sob diferentes densidades de plantas, em época de semeadura safrinha

\begin{tabular}{|c|c|c|c|c|c|c|}
\hline \multirow{2}{*}{ Cultivares } & \multicolumn{5}{|c|}{ Densidades (plantas $\mathrm{m}^{-1}$ ) } & \multirow{2}{*}{ Médias } \\
\hline & 2 & 3 & 4 & 5 & 6 & \\
\hline C 11 & 2,44 & 2,22 & 2,31 & 2,23 & 2,22 & $2,28 b$ \\
\hline M 734 & 2,54 & 2,45 & 2,24 & 2,34 & 2,26 & $2,37 a$ \\
\hline Média & 2,49 & 2,34 & 2,28 & 2,28 & 2,24 & \\
\hline $\begin{array}{c}\text { D.M.S. }{ }^{1} \\
\text { Diferença } \mathrm{n}\end{array}$ & $\begin{array}{l}0,06 \\
\text { a signific }\end{array}$ & & $\begin{array}{l}\text { C.V. (\%) } \\
\text { los origin }\end{array}$ & 3,43 & & \\
\hline
\end{tabular}

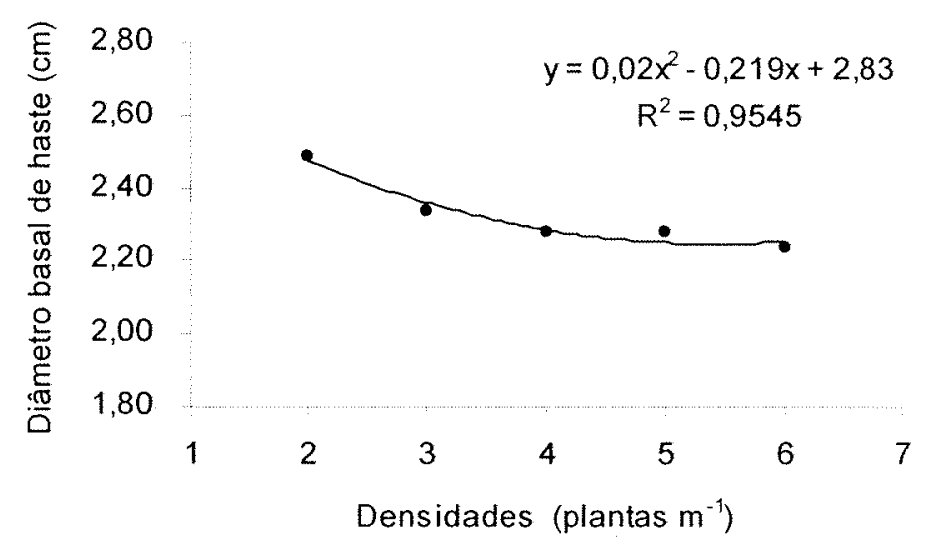

Figura 22 - Diâmetro basal de haste $(\mathrm{cm})$ dos cultivares de girassol C 11 e M 734, em função da densidades de plantas na linha, em época de semeadura safrinha.

\subsubsection{Diâmetro de capítulo (DC)}

Para essa variável, a análise de variância mostrou haver independência entre os fatores cultivar e densidade, pois a interação entre eles não se revelou significativa. Para efeito de cultivar, Morgan 734 produziu, em média, diâmetro de capítulo maior quando comparado a Cargill 11 (Tabela 32), tendo contribuído para isto, a altura final de planta e o número de folhas formadas.

No caso do fator densidade, a análise de variância não apresentou valores de $F$ significativos para os modelos testados. Dessa forma, o modelo de regressão não apresentou qualidade de ajuste, pois os valores da variável diâmetro de 
capitulo mostraram-se pouco variável em relação as diferentes densidades. Tal resultado discorda dos obtidos por Rajput et al. (1994) e Ungaro et al. (1996), que encontraram redução no diâmetro de capítulo conforme aumento no número de plantas por metro.

Tabela 32. Diâmetro de capítulo $(\mathrm{cm})$ de cultivares de girassol, manejados sob diferentes densidades de plantas, em época de semeadura safrinha

\begin{tabular}{|c|c|c|c|c|c|c|}
\hline \multirow{2}{*}{ Cultivares } & \multicolumn{5}{|c|}{ Densidades (plantas $\mathrm{m}^{-1}$ ) } & \multirow{2}{*}{ Médias } \\
\hline & 2 & 3 & 4 & 5 & 6 & \\
\hline C 11 & $17,89^{1}$ & 16,15 & 15,45 & 15,02 & 12,84 & $15,43 b$ \\
\hline M 734 & 18,83 & 18,84 & 15,85 & 16,39 & 16,99 & $17,36 \mathrm{a}$ \\
\hline Média & 18,36 & 17,47 & 15,64 & 15,70 & 14,85 & \\
\hline $\begin{array}{l}\text { D.M.S. } \\
\text { a tabela e } \\
\text { nsformados } \\
\text { ifferença mir }\end{array}$ & $\begin{array}{l}0,22 \\
\text { tram-se } \\
\text { indo } \sqrt{ } x \\
\text { significa }\end{array}$ & res & $\begin{array}{l}\text { C.V. (\%) } \\
\text { nais, mas }\end{array}$ & $\begin{array}{l}6,88 \\
\text { fins }\end{array}$ & alise & lados fora \\
\hline
\end{tabular}

\subsubsection{Número de aquênios por capítulo (NA)}

A análise de variância para número de aquênios por capitulo de girassol, revelou valores de $\mathrm{F}$ significativos para o fator cultivar e para o fator densidade, mas não para a interação, revelando independência entre os fatores.

Entre cultivares, apesar de Morgan 734 apresentar maior diâmetro de capítulo, mostrou-se significativamente inferior quanto ao número de aquênios por capítulo em relação a Cargill 11 (Tabela 33). A ocorrência de temperaturas mínimas abaixo de 13 a $14^{\circ} \mathrm{C}$ no período da antese (Tabela 1 ), afetou a fecundação das flores e a produção de aquênios ${ }^{7}$, sendo este efeito observado em todas as densidades. Desse modo, Morgan 734 seria mais sensivel a baixas temperaturas durante a antese que Cargill 11.

Blamey et al. (1997) cita que o girassol é susceptível à baixas temperaturas durante as fases $R_{4}$ e $R_{5}$ (antese), resultando em destruição do pólen e ausência

\footnotetext{
${ }^{7}$ CASTRO, C. de (EMBRAPA. Centro Nacional de Pesquisa de Soja, Londrina). Comunicação pessoal, 2000.
} 
de fertilização, com formação de anéis de floretes inférteis. Utilizando dois niveis de radiação solar (9,5 e 25,5 $\mathrm{MJ} \mathrm{dia}^{-1}$ ) e cinco regimes térmicos (dia/noite): $30^{\circ} / 25^{\circ} ; 27^{\circ} / 22^{\circ} ; 24^{\circ} / 19^{\circ} ; 21^{\circ} / 16^{\circ} ; 18^{\circ} / 13^{\circ}$ (verão) e $15^{\circ} / 10^{\circ}$ (inverno), Rawson et al. (1984) observaram que nesse último, foram obtidos os menores valores para número total de aquênios, número e peso de aquênios cheios, e também maior peso de capítulo chocho.

No estudo de densidade, o teste $F$ da análise de regressão polinomial apresentou diferenças significativas ao nível de $5 \%$ de probabilidade, constatado por meio de regressão linear. Para cada aumento no número de plantas na linha, obtém-se decréscimos significativos no número de aquênios por capítulo (Figura 23). Este desempenho também foi verificado por Radford (1978), Miller et al. (1984), Cardinali et al. (1985), Silva e Nepomuceno (1991) e Carvalho et al. (199195). 
Tabela 33. Número de aquênios por capítulo de cultivares de girassol, manejados sob diferentes densidades de plantas, em época de semeadura safrinha

\begin{tabular}{|c|c|c|c|c|c|c|}
\hline \multirow{2}{*}{ Cultivares } & \multicolumn{5}{|c|}{ Densidades (plantas $\mathrm{m}^{-1}$ ) } & \multirow{2}{*}{ Médias } \\
\hline & 2 & 3 & 4 & 5 & 6 & \\
\hline C 11 & $1192,48^{1}$ & 1045,78 & 1098,76 & 788,69 & 752,51 & 967,64 a \\
\hline M 734 & 660,34 & 616,42 & 531,94 & 486,95 & 539,81 & $565,39 \mathrm{~b}$ \\
\hline Média & 906,90 & 817,01 & 789,95 & 628,78 & 641,76 & \\
\hline D.M.S. ${ }^{2}$ & 2,21 & & C.V. (\%) & 10,48 & & \\
\hline
\end{tabular}

${ }^{1} \mathrm{Na}$ tabela encontram-se os valores originais, mas para fins de análise os dados foram transformados segundo $\sqrt{x+0,5}$

${ }^{2}$ Diferença minima significativa obtida dos dados transformados.

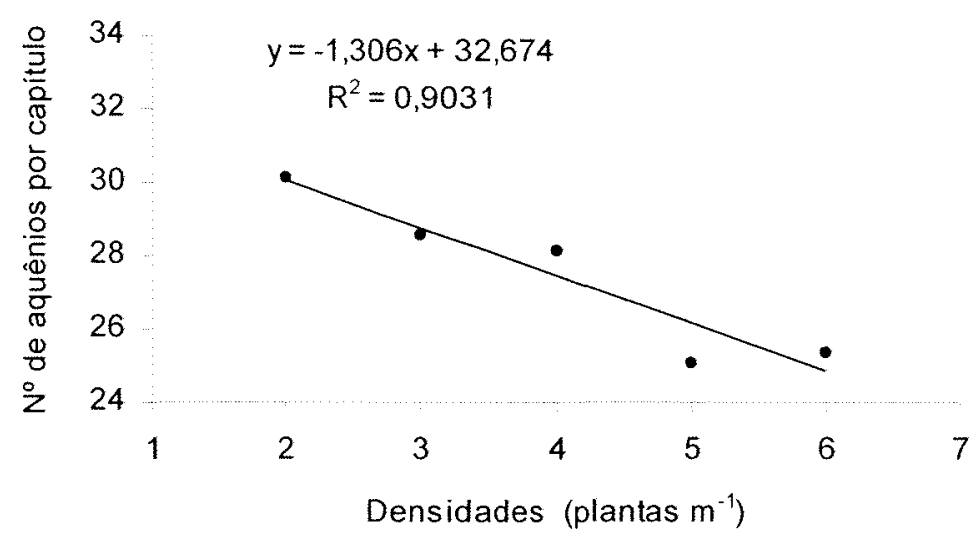

Figura 23 - Número de aquênios por capítulo dos cultivares de girassol C 11 e M 734, em função da densidades de plantas na linha, em época de semeadura safrinha.

\subsubsection{Massa de mil aquênios (M1000)}

Para massa de mil aquênios, a análise de variância revelou valores com diferenças significativas para os fatores cultivar e densidade, mas não para a interação entre eles, revelando que o efeito da densidade é independente do cultivar.

Para efeito de cultivar, Morgan 734 apresentou maior massa de mil aquênios, quando comparado a Cargill 11 (Tabela 34), apesar de apresentar menor número 
de aquênios por capítulo. Para essa variável, a diferença de resposta entre os cultivares, em função da densidade de plantas, está relacionada a características genéticas.

Quanto ao fator densidade, foi constatado por meio de regressão linear (Figura 24), que aumento na densidade de plantas causa diminuição significativa na massa de mil aquênios, como conseqüência direta da redução também ocorrida para diâmetro de capítulo e número de aquênios por capítulo, mostrando que para aumento de uma planta na linha, ocorre decréscimo de $2,1 \mathrm{~g}$ na massa de mil aquênios.

De acordo com Vrânceanu (1977), plantas de girassol conduzidas em baixas densidades, apresentaram aumentos no tamanho dos aquênios e na porcentagem de casca, em prejuizo da formação de outros componentes do aquênio, como a amêndoa. Decréscimos no componente massa de 1000 aquênios com o aumento da população de plantas também foram observados por Miller et al. (1984), Silva e Nepomuceno (1991) e Carvalho et al. (1991-95).

Segundo Cardinali et al. (1985), em cultivar de ciclo curto, o aumento da densidade de plantio de 10.000 para 50.000 plantas ha $^{-1}$, influiu principalmente, na redução de $54 \%$ na massa de 1000 aquênios, enquanto que para o número de aquênios, esta redução foi de $20 \%$. No estudo de Andrade (1995), o girassol apresentou uma alta capacidade de compensar o baixo número de grãos por área com grãos mais pesados. 
Tabela 34. Massa de 1000 aquênios ( $\mathrm{g}$ ) de cultivares de girassol, manejados sob diferentes densidades de plantas, em época de semeadura safrinha

\begin{tabular}{|c|c|c|c|c|c|c|}
\hline \multirow{2}{*}{ Cultivares } & \multicolumn{5}{|c|}{ Densidades (plantas $\mathrm{m}^{-1}$ ) } & \multirow{2}{*}{ Médias } \\
\hline & 2 & 3 & 4 & 5 & 6 & \\
\hline C 11 & 52,08 & 50,07 & 48,22 & 47,67 & 42,82 & $48,17 \mathrm{~b}$ \\
\hline M 734 & 71,27 & 65,13 & 61,79 & 61,50 & 62,65 & $64,47 \mathrm{a}$ \\
\hline Média & 61,67 & 57,60 & 55,00 & 54,59 & 52,74 & \\
\hline D.M.S. ${ }^{1}$ & 2,14 & tis & C.V. $(\%)$ & 4,96 & & \\
\hline
\end{tabular}

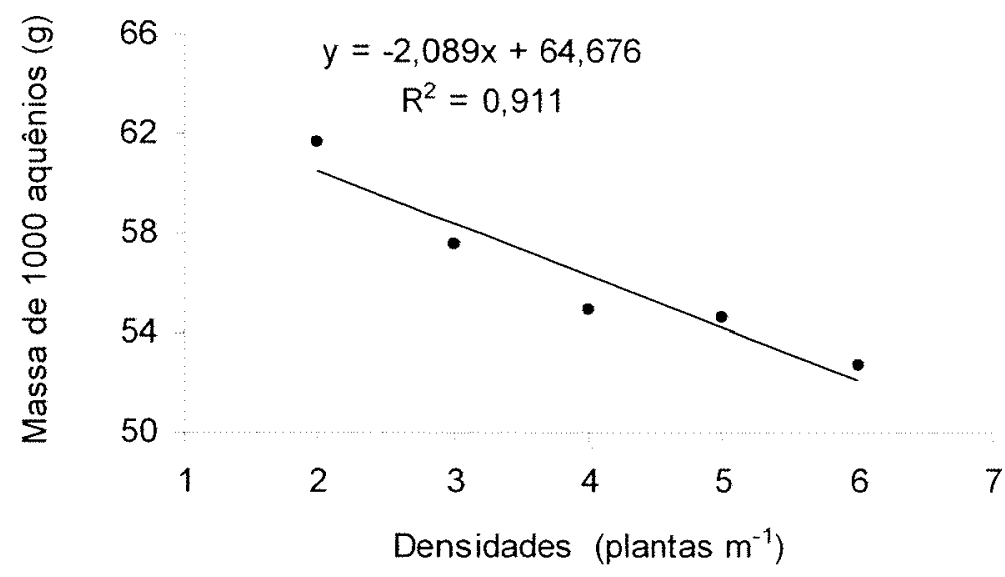

Figura 24 - Massa de mil aquênios dos cultivares de girassol C 11 e M 734, em função das densidades de plantas na linha, em época de semeadura safrinha.

\subsubsection{Rendimento em aquênios (REND)}

$O$ rendimento em aquênios foi afetado significativamente apenas pelo fator cultivar $(P>0,05)$, constatado pela análise de variância que revelou valores $F$ significativos, mas não apresentando efeitos significativos para o fator densidade $e$ também para a interação entre os fatores.

Cargill 11 apresentou produtividade agrícola em aquênios significativamente superior a Morgan 734 (Tabela 35), que teve seu rendimento prejudicado pelo 
efeito das baixas temperaturas ocorridas durante o florescimento sobre o componente número de aquênios por capitulo.

O número de aquênios (por planta ou por área) é o principal determinante do rendimento, pois, cada estádio da formação e do crescimento dos floretes, define um componente que altera o rendimento potencial da cultura (Connor e Sadras, 1992).

No estudo de densidade, a produtividade agrícola em aquênios não apresentou diferenças significativas, não permitindo ajuste de qualidade para modelos de regressão. Tal resultado discorda de Sarmah et al. (1992) e Sobarad et al. (1996), que verificaram resposta do rendimento de aquênios ao fator densidade de plantas. Este desempenho pode ter ocorrido em conseqüência dos decréscimos observados nos componentes de rendimento, número de aquênios por capítulo e massa de 1000 aquênios, que foram compensados com o aumento no número de plantas, permitindo manter um rendimento relativamente constante, concordando com os resultados obtidos por Miller et al. (1984), Cardinali et al. (1985) e Carvalho et al. (1991-95), que também encontraram efeito compensatório entre os componentes de rendimento.

Tabela 35. Rendimento em aquênios $\left(\mathrm{kg} \mathrm{ha}^{-1}\right)$ de cultivares de girassol, manejados sob diferentes densidades de plantas, em época de semeadura safrinha

\begin{tabular}{|c|c|c|c|c|c|c|}
\hline \multirow{2}{*}{ Cultivares } & \multicolumn{5}{|c|}{ Densidades (plantas $\mathrm{m}^{-1}$ ) } & \multirow{2}{*}{ Médias } \\
\hline & 2 & 3 & 4 & 5 & 6 & \\
\hline C 11 & 1480,99 & 1580,03 & 1839,39 & 1440,33 & 1483,56 & $1564,86 a$ \\
\hline M 734 & 1314,82 & 1108,47 & 1185,70 & 1284,86 & 1177,61 & $1214,29 b$ \\
\hline Média & 1397,91 & 1344,25 & 1512,55 & 1362,60 & 1330,58 & \\
\hline D.M.S. ${ }^{1}$ & 181,30 & & C.V. (\%) & 17,01 & & \\
\hline
\end{tabular}

$\mathrm{Na}$ tabela 36, encontram-se as correlações de Pearson entre o rendimento de aquênios, seus componentes e índice de colheita. Valores altos de correlação foram obtidos entre o rendimento de aquênios e o indice de colheita $(r=0,8365)$ e 
também para número de aquênios por capítulo $(r=0,8164)$, mostrando que, a medida que $o$ índice de colheita e o número de aquênios aumentam, há significativo aumento no rendimento. Carvalho et al. (1991-95), também encontrou correlação significativa entre rendimento e número de aquênios $m^{-2}(0,92)$. No caso do índice de colheita, este resultado já era esperado, pois é definido através da relação entre o rendimento de aquênios sobre a massa seca total. Para número de aquênios por capítulo, essa alta correlação ressalta a importância desse componente na determinação do rendimento final de girassol, conforme relatado por Connor e Sadras (1992).

Para a variável massa de 1000 aquênios, foi observada uma alta correlação negativa com o rendimento de aquênios $(r=-0,7307)$, revelando que a medida que o valor da massa aumenta, há redução significativa no rendimento, atribuído ao efeito compensatório entre número de aquênios por capítulo e massa de 1000 aquênios, observado também por Andrade (1995). Em contrapartida, uma baixa correlação positiva entre rendimento de aquênios e massa de 1000 aquênios $(0,49)$, foi encontrada por Carvalho et al. (1991-95).

Tabela 36. Estimativa dos coeficientes de correlação simples ( $r$ ) entre características agronômicas com o rendimento em aquênios para os cultivares de girassol C 11 e M 734, manejados sob diferentes densidades de plantas, em época de semeadura safrinha

\begin{tabular}{ccc}
\hline Caract. Agron. & REND & Prob $>t$ \\
\hline IC & 0,8365 & 0,0013 \\
DC & $-0,4382$ & 0,1026 \\
M1000 & $-0,7307$ & 0,0082 \\
NA & 0,8164 & 0,0020 \\
\hline
\end{tabular}

De maneira geral, os coeficiente de correlação de Pearson entre a massa seca e índice de área foliar e, os componentes de rendimento de girassol, foram baixos (Tabela 37). As maiores correlações ocorreram entre o diâmetro de capítulo e o índice de área foliar em pleno desenvolvimento vegetativo $(r=-0,766)$ e no 
período de desenvolvimento de aquênios $(r=-0,704)$, mostrando que diminuição no indice de área foliar durante essas fases, ocasiona aumento significativo no diâmetro de capítulo. Boas correlações ocorreram também entre massa seca total e número de aquênios, variando entre - 0,498 e -0,707, indicando que em todas as fases do desenvolvimento da cultura, aumento da matéria seca ocasionou diminuição do número de aquênios. Para massa de mil aquênios e rendimento, algumas correlações foram boas, porém, não significativas. 
Tabela 37. Estimativa dos coeficientes de correlação simples $(r)$ entre a matéria seca e indice de área foliar e os componentes de rendimento para os cultivares de girassol C 11 e M 734, manejados sob diferentes densidades de plantas, em época de semeadura safrinha

\begin{tabular}{|c|c|c|c|c|c|c|c|c|c|}
\hline$E F^{1}$ & Variáveis & DC & Prob $>t$ & NA & Prob $>t$ & M1000 & Prob $>t$ & REND & Prob $>t$ \\
\hline \multirow{2}{*}{$V_{12}$} & MS & $-0,662$ & 0,0185 & $-0,498$ & 0,0716 & $-0,269$ & 0,2261 & $-0,139$ & 0,3506 \\
\hline & IAF & $-0,301$ & 0,1991 & $-0,195$ & 0,2950 & $-0,173$ & 0,3166 & 0,051 & 0,4448 \\
\hline \multirow{2}{*}{$V_{21}$} & MS & $-0,407$ & 0,1215 & $-0,512$ & 0,0650 & $-0,082$ & 0,4107 & $-0,096$ & 0,3965 \\
\hline & IAF & $-0,766$ & 0,0050 & 0,009 & 0,4904 & $-0,643$ & 0,0226 & 0,405 & 0,1231 \\
\hline \multirow{2}{*}{$\mathrm{R}_{2}$} & MS & $-0,442$ & 0,1003 & $-0,573$ & 0,0416 & $-0,123$ & 0,3671 & $-0,416$ & 0,1160 \\
\hline & IAF & $-0,210$ & 0,2800 & $-0,551$ & 0,0496 & 0,018 & 0,4805 & $-0,453$ & 0,0942 \\
\hline \multirow{2}{*}{$R_{4}$ e $R_{5.1}$} & MS & $-0,365$ & 0,1501 & $-0,707$ & 0,0112 & 0,086 & 0,4064 & $-0,401$ & 0,1257 \\
\hline & IAF & 0,165 & 0,3246 & 0,320 & 0,1834 & $-0,076$ & 0,4169 & 0,265 & 0,2300 \\
\hline \multirow{2}{*}{$R_{5.6}$ e $R_{5.8}$} & MS & $-0,356$ & 0,1569 & $-0,529$ & 0,0581 & 0,005 & 0,4951 & $-0,309$ & 0,1929 \\
\hline & IAF & 0,259 & 0,2352 & $-0,004$ & 0,4959 & 0,038 & 0,4587 & $-0,379$ & 0,1394 \\
\hline \multirow{2}{*}{$R_{6}$} & MS & $-0,362$ & 0,1518 & $-0,664$ & 0,0182 & 0,058 & 0,4363 & $-0,374$ & 0,1433 \\
\hline & IAF & $-0,356$ & 0,1565 & $-0,459$ & 0,0912 & 0,139 & 0,3513 & $-0,116$ & 0,3748 \\
\hline \multirow{2}{*}{$\mathrm{R}_{7}$ e $\mathrm{R}_{8}$} & MS & $-0,454$ & 0,0935 & $-0,668$ & 0,0174 & $-0,001$ & 0,5000 & $-0,257$ & 0,2370 \\
\hline & IAF & $-0,704$ & 0,0115 & $-0,245$ & 0,2477 & $-0,437$ & 0,1034 & 0,141 & 0,3487 \\
\hline
\end{tabular}

'Estádio Fenológico 


\section{CONCLUSÕES}

a) A produção de massa seca é influenciada pelo fator genótipo, com Morgan 734 apresentando maior produção a partir do início do florescimento.

b) A densidade de 6 plantas $\mathrm{m}^{-1}$ proporciona maior produção de massa seca total.

c) O índice de área foliar não é influenciado pelos fatores densidade de plantas e genótipo.

d) O aumento da densidade de plantas na linha, aumenta a taxa de crescimento da cultura de girassol.

e) Para taxa de crescimento relativo, os cultivares apresentam desempenho diferenciado condicionada à densidade de plantas.

f) O aumento na densidade de plantas na linha, decresce a taxa assimilatória líquida, razão de área foliar e o índice de colheita.

g) $\mathrm{O} n^{\circ}$ de aquênios por capitulo, é o componente da produção da planta mais importante para a determinação da produtividade agricola de girassol do que massa de aquênios, perante a ocorrência de temperaturas baixas na antese. 
h) $O$ aumento na densidade de plantio diminui o $n^{\circ}$ de folhas, o diâmetro de haste, o $n^{0}$ de aquênios por capitulo e a massa de aquênios de girassol.

i) A diminuição do $n^{\circ}$ de aquênios por capítulo e da massa de aquênios com o aumento da densidade de planta na linha, é compensada pelo maior $n^{\circ}$ de plantas por unidade de área, não afetando a produtividade agrícola de girassol.

j) Cargill 11 apresenta maior produtividade agricola que Morgan 734 , porém essa diferença foi devido ao efeito de baixas temperaturas na antese. 
ANEXOS 


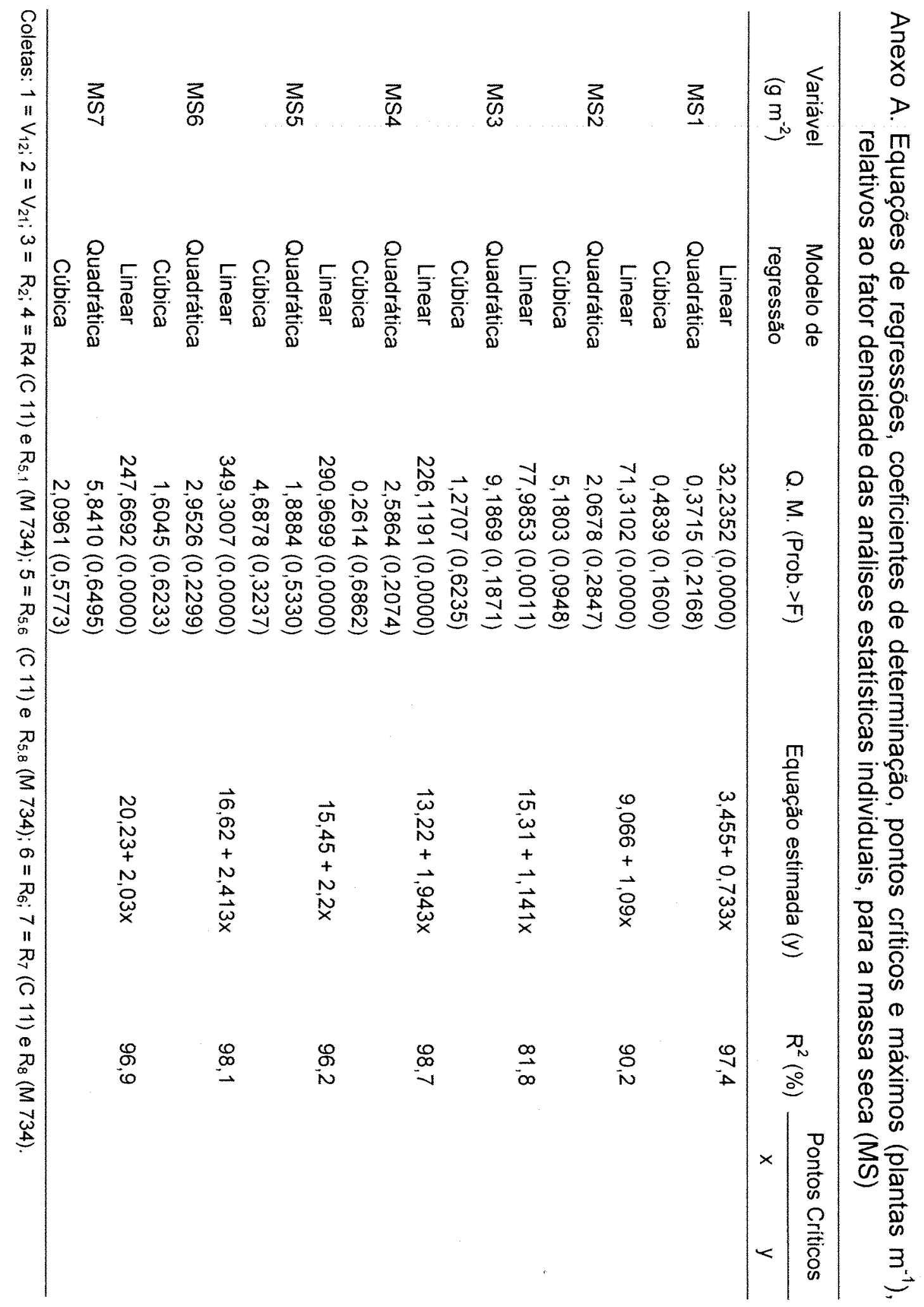




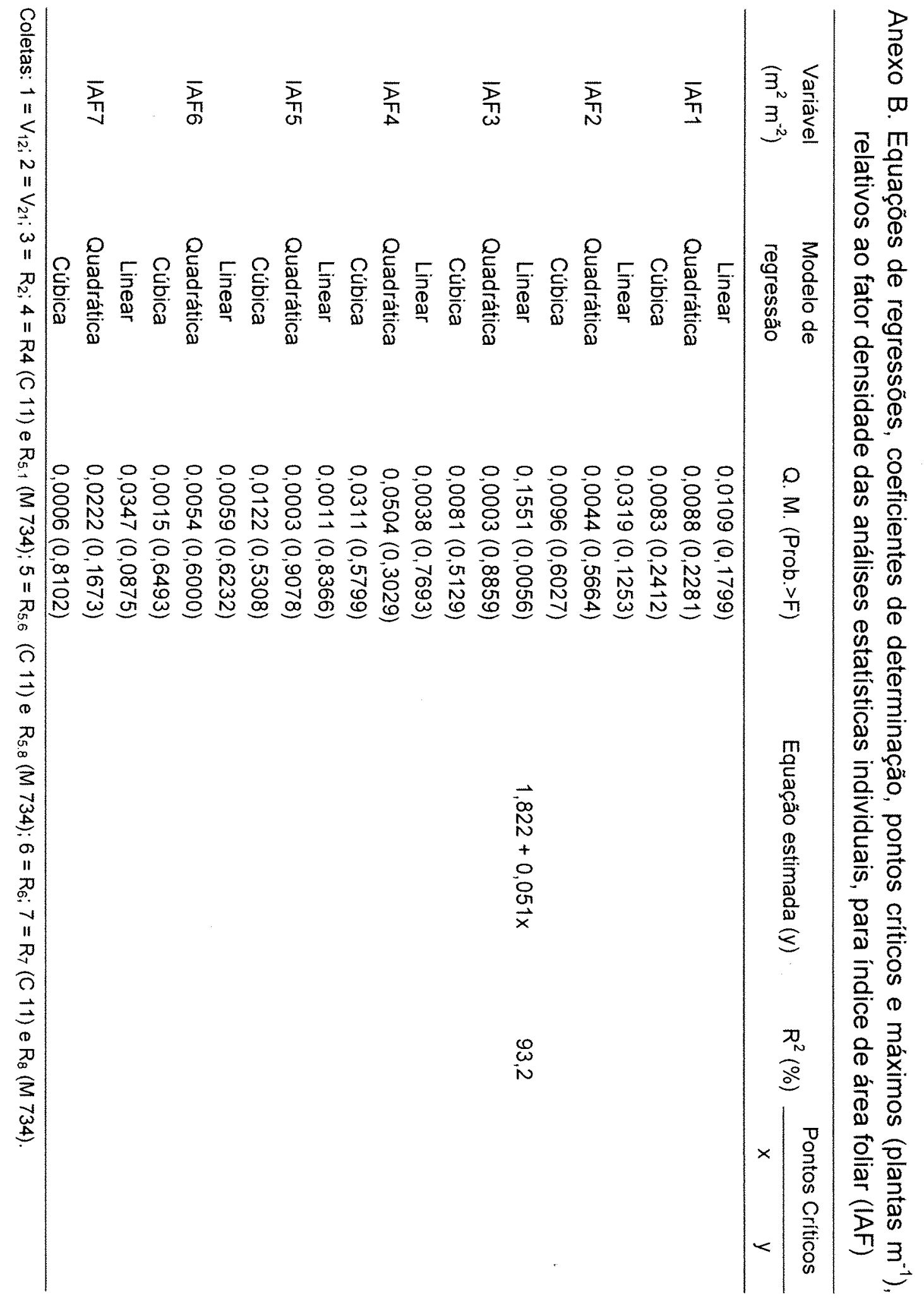




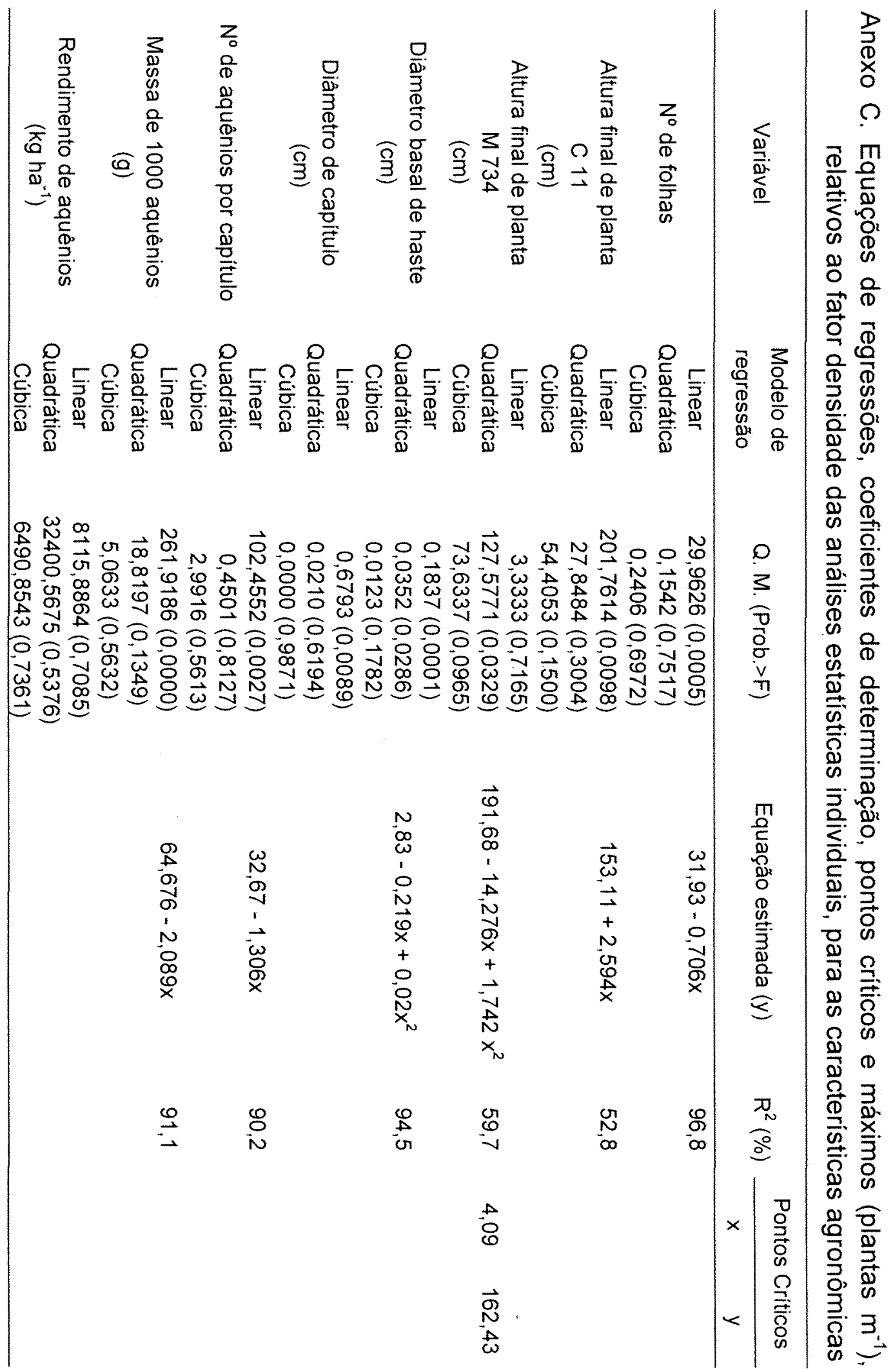




\section{'REFERÊNCIAS BIBLIOGRÁFICAS}

AGUIRREZÁBAL, L. A. ; ORIOLI, G. A.; PEREYRA, V. R. Relacion entre area foliar y rendimento en un cultivar enano de girasol. In: REUNION TECNICA DE GIRASOL, 5., Bahia Blanca, 1987. Actas. Bahia Blanca: ASAGIR; Universidad Nacional del Sur, 1987. p.35-39.

ALMEIDA, M. L. de; SILVA, P. R. F. da Efeito da densidade e época de semeadura e de adubação nas caracteristicas agronômicas do girassol. I. Rendimento de grãos e óleo e seus componentes. Pesquisa Agropecuária Brasileira, v.28, n.7, p.833-841, 1993.

ANDRADE, F. H. Analysis of growth and yield of maize, sunflower and soybean grown at Balcarce, Argentina. Field Crops Research, v.41, n.1, p.1-12, 1995.

BANGE, M. P.; HAMMER, G. L.; RICKERT, K. G. Environmental control of potencial yield of sunflower in the subtropics. Australian Journal of Agricultural Research, v.48, n.2, p.231-240, 1997.

BARNI, N. A.; BERLATO, M. A.; BERGAMASCHI, H.; RIBOLDI, J. Rendimento máximo do girassol com base na radiação solar e temperatura: II. Produção de fitomassa e rendimento de grãos. Pesquisa Agropecuária Gaúcha, v.1, n.2, p.201-216, 1995a. 
BARNI, N. A.; BERLATO, M. A.; SANTOS, A. O.; SARTORI, G. Análise de crescimento do girassol em resposta a cultivares, niveis de adubação e épocas de semeadura. Pesquisa Agropecuária Gaúcha, v.1, n.2, p.167184, 1995b.

BENINCASA, M. M. P. Análise de crescimento de plantas (noções básicas). Jaboticabal: FUNEP, 1988. 42p.

BLACKMAN, V. H. The compound interest law and plant growth. Annals of Botany, v.33, p.353-360, 1919.

BLAMEY, F. P. C.; ZOLLINGER, R. K.; SCHNEITER, A. A. Sunflower production and culture In: SCHNEITER, A. A. (Ed.) Sunflower technology and production. 2. ed. Madison: American Society of Agronomy, 1997. p.595-696. (Agronomy, 35).

BLANCHET, R.; MERRIEN, A.; GELFI, N.; ROLLIER, M. Evolution of biosynthesis during the cicle of development of sunflower and assimilates partition among organs and constituients. In: INTERNATIONAL SUNFLOWER CONFERENCE, 10., Surfers Paradise, 1982. Proceedings. Surfers Paradise: Int. Sunflower Assoc., 1982. p.29-33.

BRASIL. Ministério da Agricultura e Reforma Agrária. Regras para análise de sementes, Brasília: SNDA; DNDV; CLAV, 1992. 365p.

BRIGGS, G. E.; KIDD, F. A.; WEST, C. A quantitative analysis of plant growth. Annals of Applied Biology, v.7, p.202-223, 1920. 
CAMPBELL, A. T.; ATHAYDE, M. L. F. Efeito da semeadura no comportamento de dois genótipos de girassol. Pesquisa Agropecuária Brasileira, v.23, n.4, p.379-386, 1988.

CARDINALI, F. J.; ORIOLI, G. A.; PEREYRA, V.R. Comportamiento de dos hibridos de girasol a bajas densidades de siembra. Revista de la Facultad de Agronomía, v.6, n. 3, p.131-139, 1985.

CARTER, J. F. Sunflower science and technology, Madison: American Society of Agronomy, 1978. 505p. (Agronomy, 19).

CARVALHO, M. J G. P. R.; BASCH, G.; AZEVEDO, A. L.; MACHADO, L. C. R. T. Efeitos de datas e densidades de sementeira na cultura do girassol, em solos de Barro Preto (Bp). Agronomia Lusitana, v.45, n.1/3, p.137-158, 1991-95.

CASTIGLIONI, V. B. R.; BALLA, A.; CASTRO, C. de; SILVEIRA, J. M. Fases de desenvolvimento da planta de girassol. Londrina: EMBRAPA, CNPSo, 1994. 24p. (EMBRAPA. CNPSo. Documentos, 58).

CENTRE TECHNIQUE INTERPROFESSIONNEL DES OLÉAGINEUX MÉTROPOLITAINS. Physiologie du tournesol. Paris, 1992. 66p.

CONNOR, D. J.; HALL. A. J. Sunflower physiology. In: SCHNEITER, A. A. (Ed.) Sunflower technology and production. 2. ed. Madison: American Society of Agronomy, 1997. p.113-182. (Agronomy, 35).

CONNOR, D. J.; SADRAS, V. O. Physiology of yield expression in sunflower. Field Crops Research, v.30, p.333-374, 1992. 
COX, W. J.; JOLIFF, G. D. Growth and yield of sunflower and soybean under soil water deficits. Agronomy Journal, v.78, p.226-230,1986.

COX, W. J.; JOLIFF, G. D. Crop water relations of sunflower and soybean under irrigated and dryland conditions. Crop Science, v.27, p.553557,1987 .

EMPRESA BRASILEIRA DE PESQUISA AGROPECUÁRIA. Indicações técnicas para o cultivo do girassol, Londrina: EMBRAPA, CNPSo, 1983. 40p. (EMBRAPA. CNPSo. Documentos, 3).

EMPRESA BRASILEIRA DE PESQUISA AGROPECUÁRIA. Informes da avaliação de genótipos de girassol, 1998/99 e 1999/Embrapa Soja, Londrina: EMBRAPA, CNPSo, 1999. 99p. (EMBRAPA. CNPSo. Documentos, 137).

ENGLISH, S. D.; McWILLIAM, J. R.; SMITH, R. C. G.; DAVIDSON, J. L. Photosynthesis and partitioning of dry matter in sunflower. Australian Journal of Plant Physiology, v.6, p.149-164, 1979.

FELIPPE, G. M. Desenvolvimento. In: FERRI, M. G. Fisiologia vegetal. São Paulo: EPU, 1985. v.2, p.1-37.

GÓMEZ-ARNAU, J. El cultivo del girasol. Hojas Divulgadoras, n.20, p. 1-31, 1988.

GONÇALVES, N. P.; KAKIDA, J.; MARINATO, R.; ALMEIDA, T. de C.; Época, espaçamento, densidade de plantio e irrigação para a cultura do girassol. Informe Agropecuário, v.7, n.82, p.78-79, 1981. 
HALL, A. J.; WHITFIELD, D. M.; CONNOR, D. J. Contribution of pre-anthesis assimilates to grain filling in irrigated and water-stressed sunflower crops. II. Estimates from a carbon budget. Field Crops Research, v.24, p.273-294, 1990.

HUNT, R. Plant growth curves: the functional aproach to plant growth analysis. London: Edward Arnold, 1982. 248p.

JAAFAR, M. N.; STONE, L. R.; GOODRUM, D. E. Rooting depth and dry matter development of sunflower. Agronomy Journal, v.85, n.2, p.281286, 1993.

LUCCHESI, A. A. A Utilização prática da análise quantitativa do crescimento vegetal. Anais da Escola Superior de Agricultura "Luiz de Queiroz", v.41, n.1, p.181-202, 1984.

MACHADO, E. C.; PEREIRA, A. R.; FAHL, J. I.; ARRUDA, H. V.; SILVA, W. J. da; TEIXEIRA, J. P. F. Análise quantitativa de crescimento de quatro variedades de milho em três densidades. Pesquisa Agropecuária Brasileira, v.17, n.6, p.825-833, 1982.

MAGALHÄES, A. C. N. Análise quantitativa do crescimento. In: FERRI, M. G. Fisiologia vegetal. São Paulo: EPU, 1985. v.1, p.350-363.

MERRIEN, A. Physiologie du tournesol. Paris: CETIOM, 1992.66p.

MILLER, B. C.; OPLINGER, E. S.; RAND, R.; PETERS, J.; WEIS. G. Effect of planting date and plant population on sunflower performance. Agronomy Journal, v.76, p.511-515, 1984. 
NAKAGAWA, J.; MACHADO, J. R.; SILVA, M. N. da; MARTHE, L. A. Q. Efeito da população de plantas no comportamento de girassol em cultivo da seca, Cientifica, v. 17, n. 1, p. 73-82, 1989.

PEIXOTO, C. P. Análise de crescimento e rendimento de três cultivares de soja em três épocas de semeadura e três densidades de plantas. Piracicaba, 1998. 151p. Tese (Doutorado) - Escola Superior de Agricultura "Luiz de Queiroz", Universidade de São Paulo.

PEREIRA, A. R.; MACHADO, E. C. Análise quantitativa do crescimento de vegetais. Campinas: Instituto Agronômico, 1987. 33p. (IAC. Boletim Técnico, 114).

PÉREZ NIETO, J.; CÁGAL, M. V.; ZAVALETA, C. y R. Analisis de crecimento y su relacion con el rendimiento economico en girasol (Helianthus annuus L.). Chapingo, n.77, p.48-51, 1992.

QUAGGIO, J. A.; UNGARO, M. R. G. Girassol. In: RAIJ, B. van.; CANTARELLA, H.; QUAGGIO, J. A.; FURLANI, A. M. C. (Ed.) Recomendações de adubação e calagem para o Estado de São Paulo. 2. ed. Campinas: IAC, 1996. cap. 9, p.198. (IAC. Boletim Técnico, 100).

RADFORD, B. J. Plant population and row spacings for irrigated and rainfed oilseed sunflowers (Helianthus annuus L.) on the Darling Downs. Australian Journal of Experimental Agriculture and Animal Husbandry, v.18, p.135-142, 1978.

RAIJ, B. van.; CANTARELLA, H.; QUAGGIO, J. A.; FURLANI, A. M. C. (Ed.) Recomendações de adubação e calagem para o Estado de São Paulo. 2. ed. Campinas: IAC, 1996. 285p. (IAC. Boletim Técnico, 100). 
RAJPUT, A. L.; SINGH, D. P.; SINGH, S. P. Effect of spacing and method of nitrogen application on quality and seed yield of sunflower (Helianthus annuus L.), Indian Journal Agronomy, v. 39, n. 3, p. 493-95, 1994.

RAWSON, H. M.; CONSTABLE, G. A. Carbon production of sunflower cultivars in field and controlled environments. I. Photosynthesis and transpiration of leaves, stems and heads. Australian Journal of Plant Physiology, v.7, p. 555-573, 1980.

RAWSON, H. M.; DUNSTONE, R. L.; LONG, M. J.; BEGG, J. E. Canopy development, light interception and seed production in sunflower as influenced by temperature and radiation. Australian Journal of Plant Physiology, v.11, p.1255-1265, 1984.

REIS, G. G.; MULLER, M. W. Análise de crescimento de plantas mensuração do crescimento. Belém: CPATU, 1979. 35p.

RIZZARDI, M. A.; SILVA, P. R. F. da Partição de matéria seca e óleo nos aquênios de girassol em função da densidade de plantas. Revista Brasileira de Fisiologia Vegetal, v.4, n.2, p.113-116, 1992.

RIZZARDI, M. A.; SILVA, P. R. F. da Resposta de cultivares de girassol à densidades de plantas em duas épocas de semeadura. I. Rendimento de grãos e óleo e componentes do rendimento. Pesquisa Agropecuária Brasileira, v.28, n.6, p.675-687, 1993.

SADRAS, V. O.; VILLALOBOS, F. J. Floral initiation, leaf initiation and leaf appearance in sunflower. Field Crops Research, v.33, p.449-457, 1993. 
SARDER, R.; ADAMO, P. E.; MATTOS JÚNIOR, D. de; GAVIOLI, E. A. Efeito da época de semeadura na produção e qualidade de sementes de girassol (Helianthus annuus L.) Científica, v.19, n.1, p.93-101, 1991a.

SARDER, R.; TAVARES, L. C. V.; GAVIOLI, E. A.; MATTOS JÚNIOR, D. de Efeito da densidade de plantas na produção e qualidade de sementes de girassol (Helianthus annuus L.) Científica, v.19, n.1, p.143-150, $1991 \mathrm{~b}$.

SARMAH, P. C.; KATYAL, S. K.; VERMA, O. P. S. Growth and yield of sunflower (Helianthus annuus) varieties in relation to fertility level and plant population. Indian Journal of Agronomy, v.37, n.2, p.285-289, 1992.

SCHNEITER, A. A.; MILLER, J. F. Description of sunflower growth stages. Crop Science, v.21, n.6, p.901-903, 1981.

SILVA, M. N. A cultura do girassol. Jaboticabal: FUNEP, 1990.67p.

SILVA, P. R. F. da; NEPOMUCENO, A. L. Efeito do arranjo de plantas no rendimento de grãos - componentes de rendimento, teor de óleo e no controle de plantas daninhas em girassol. Pesquisa Agropecuária Brasileira. v.26, n.9, p.1503-1508, 1991.

SILVA, P. R. F. da; RIZZARDI, M. A.; TREZZI, M. M.; ALMEIDA, M. L. de Densidade e arranjo de plantas em girassol. Pesquisa Agropecuária Brasileira, v. 30, n.6, p. 797-810, 1995.

SILVEIRA, E. P.; ASSIS, F. N. de; GONÇALVES, P. R.; ALVES, G. C. Época de semeadura do girassol no Sudeste do Rio Grande do Sul. Pesquisa Agropecuária Brasileira, v.25, n.5, p.709-720, 1990. 
SOBARAD, P.M.; SHEELAVANTAR, M. N.; CHETTI, M. B. Seed yield and growth analysis of sunflower. Indian Journal of Plant Physiology, v.1, n. 4, p.266-269, 1996.

UNGARO, M. R. G.; CRUZ, L. S. P.; AMBRÓSIO, L. A. Efeito da densidade de plantas e da modalidade de controle de mato em girassol (Helianthus annuus L.). Revista da Agricultura, v.71, n. 2, p. 165-85, 1996.

UNGARO, M. R. G.; NOGUEIRA, S. S.; ARRUDA, M. B. Growth analysis of sunflower. In: CONFERENCE INTERNATIONAL DE GIRASOL, 11., Mar del Plata, 1985. Actas. Mar del Plata : ASAGIR/ISA, 1985. p. 61-66.

UNGARO, M. R. G.; SENTELHAS, P. C; TURATTTI, J. M.; SOAVE, D. Influencia da temperatura do ar na composição de aquênios de girassol. Pesquisa Agropecuária Brasileira, v.32, n.4, p.351-356, 1997.

UNGER, P. W. Sunflower In: STEWART, B. A.; NIELSEN, D. R. (Ed.) Irrigation of agricultural crops. Madison: American Society of Agronomy, 1990. p.775-794. (Agronomy, 30).

VILLALOBOS, F. J.; HALL, A. J.; RITCHIE, J. T. Oilcrop-Sun: a growth and development simulation model of the sunflower (Helianthus annuus L.) crop. In: INTERNATIONAL SUNFLOWER CONFERENCE, 13., Pisa, 1992. Actas. Pisa: International Sunflower Organization, 1992. p.453-458.

VILLALOBOS, F. J.; HALL, A. J.; RITCHIE, J. T.; ORGAZ, F. OILCROPSUN: A development, growth and yield model of the sunflower crop. Agronomy Journal, v.88, p.403-415, 1996. 
VILLALOBOS, F. J.; SADRAS, V. O.; SORIANO, A.; FERERES, E. Planting density effects on dry matter partitioninig and productivity of sunflower hybrids. Field Crops Research, v.36, p.1-11, 1994.

VRÂNCEANU, A.V. El girasol. Madrid: Mundi-Prensa, 1977. 379p. 
APÊNDICES 

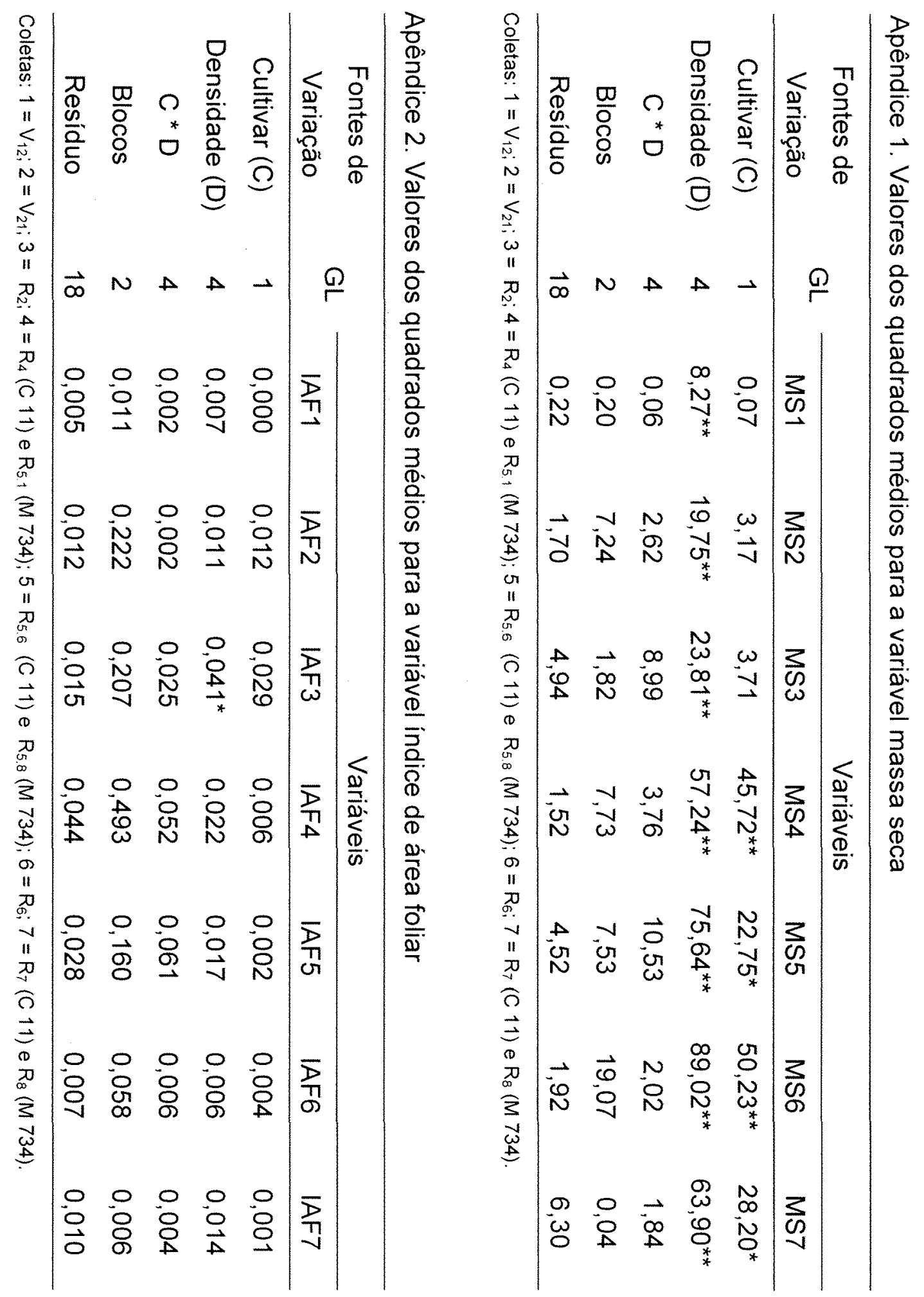


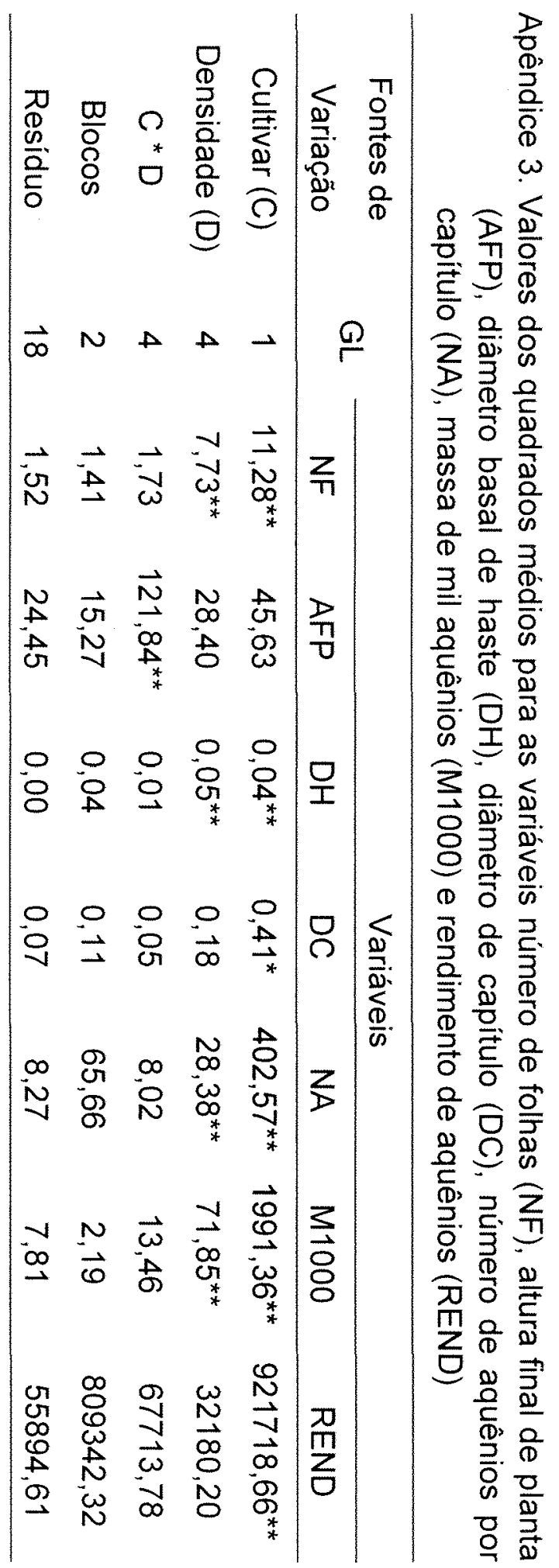

